\title{
NMDA receptor antagonist rodent models for cognition in schizophrenia and identification of novel drug treatments, an update
}

DOI:

10.1016/j.neuropharm.2017.11.045

\section{Document Version}

Accepted author manuscript

Link to publication record in Manchester Research Explorer

Citation for published version (APA):

Cadinu, D., Grayson, B., Podda, G., Harte, M., Doostdar, N., \& Neill, J. (2017). NMDA receptor antagonist rodent models for cognition in schizophrenia and identification of novel drug treatments, an update. Neuropharmacology. https://doi.org/10.1016/j.neuropharm.2017.11.045

\section{Published in:}

Neuropharmacology

\section{Citing this paper}

Please note that where the full-text provided on Manchester Research Explorer is the Author Accepted Manuscript or Proof version this may differ from the final Published version. If citing, it is advised that you check and use the publisher's definitive version.

\section{General rights}

Copyright and moral rights for the publications made accessible in the Research Explorer are retained by the authors and/or other copyright owners and it is a condition of accessing publications that users recognise and abide by the legal requirements associated with these rights.

\section{Takedown policy}

If you believe that this document breaches copyright please refer to the University of Manchester's Takedown Procedures [http://man.ac.uk/04Y6Bo] or contact uml.scholarlycommunications@manchester.ac.uk providing relevant details, so we can investigate your claim.

\section{OPEN ACCESS}




\section{Accepted Manuscript}

NMDA receptor antagonist rodent models for cognition in schizophrenia and identification of novel drug treatments, an update

Daniela Cadinu, Ben Grayson, Giovanni Podda, Michael K. Harte, Nazanin Doostdar, Joanna C. Neill

PII: S0028-3908(17)30584-1

DOI: 10.1016/j.neuropharm.2017.11.045

Reference: NP 6972

To appear in: Neuropharmacology

Received Date: 31 August 2017

Revised Date: 28 October 2017

Accepted Date: 27 November 2017

Please cite this article as: Cadinu, D., Grayson, B., Podda, G., Harte, M.K., Doostdar, N., Neill, J.C., NMDA receptor antagonist rodent models for cognition in schizophrenia and identification of novel drug treatments, an update, Neuropharmacology (2017), doi: 10.1016/j.neuropharm.2017.11.045.

This is a PDF file of an unedited manuscript that has been accepted for publication. As a service to our customers we are providing this early version of the manuscript. The manuscript will undergo copyediting, typesetting, and review of the resulting proof before it is published in its final form. Please note that during the production process errors may be discovered which could affect the content, and all legal disclaimers that apply to the journal pertain. 
NMDA receptor antagonist rodent models for cognition in schizophrenia and identification of novel drug treatments, an update.

Daniela Cadinu, Ben Grayson, Giovanni Podda, Michael K. Harte, Nazanin Doostdar, Joanna C. Neill

Division of Pharmacy and Optometry, School of Health Sciences, University of Manchester, Manchester, M13 9PT, UK

\section{Corresponding author:}

Name: Joanna Neill

Full postal address: University of Manchester, Manchester, M13 9PT, UK

Telephone: 01612752386

E-mail address: Joanna.neill@manchester.ac.uk 


\section{Contents:}

\section{Abstract}

1. Introduction

2. Novel object recognition (NOR)

3. Attentional set shifting task (ASST)
4. Operant tests

4.1 Reversal learning ( $R L$ )

4.2 Paired associates learning (PAL)

4.3 Delayed response task (DRT)

4.4 The trial-unique, delayed nonmatching-to-location (TUNL) task

4.5 Visual signal detection (SD) task

5. Neuropathology - Parvalbumin GABAergic interneurons

6. Gamma oscillations, a mediator of cognitive control

7. Discussion and conclusions

8. References 


\section{Abstract}

Negative and cognitive deficit symptoms in schizophrenia remain an unmet clinical need. Improved understanding of the neuro- and psychopathology of cognitive dysfunction in the illness is urgently required to enhance the development of new improved therapeutic strategies. Careful validation of animal models that mimic the behaviour and pathology of complex psychiatric disorders is an essential step towards this goal. Non-competitive NMDAR (N-Methyl-D-aspartate receptor) antagonists e.g. phencyclidine (PCP), ketamine and dizocilpine (MK-801) can effectively replicate certain aspects of negative and cognitive deficits associated with schizophrenia in animals. In 2010 we reviewed the effects of NMDAR antagonism in tests for domains of cognition affected in schizophrenia, social behaviour and neuropathology, and in 2014, in tests for negative symptoms. In this update, we evaluate the most recent pharmacological strategies for restoring cognition in schizophrenia using NMDAR antagonist models, published since our original review in 2010 (cited over 225 times, excluding self-citations). Tests reviewed are, novel object recognition for visual recognition memory, attentional set shifting for executive function, and operant tests incorporating recent touchscreen technology for a range of domains including working memory, problem solving and attention, all impaired in schizophrenia. Moreover, we include an update on parvalbumin (PV)expressing GABAergic interneurons and review, for the first time, the effects of NMDAR antagonists on gamma oscillations, circuitry integral for effective cognition. Data summarized in this review strongly confirm the reliability and usefulness of NMDAR antagonist animal models for evaluating novel therapeutic candidates, and for improving our understanding of the pathophysiology of cognitive deficits in schizophrenia.

Keywords: Cognition, schizophrenia, NMDAR antagonism, rodent, animal model, treatment.

Abbreviations: NMDAR, N-Methyl-D-aspartate receptor; PCP, phencyclidine; MK-801, dizocilpine; PV, parvalbumin; GABA, $\gamma$-aminobutyric acid; PFC, prefrontal cortex; CIAS, cognitive impairment associated with schizophrenia; SCPCP, sub-chronic PCP; NOR, novel object recognition; central nervous system (CNS); ITI, inter-trial interval; D, dopamine receptors; 5-HT, Serotonin 5hydroxytryptamine receptor antagonists; nAChRs, nicotinic acetylcholine receptors; PAMS, positive allosteric modulators; AChE, acetylcholinesterase inhibitor; APDs, antipsychotic drugs; AAPDs, atypical antipsychotic drugs; mAChRs, muscarinic acetylcholine receptors; NO, Nitric oxide; SNP, sodium nitroprusside; ASST, attentional set-shifting task; IDS, intra-dimensional shift; EDS, extradimensional shift; mPFC, medial prefrontal cortex; NAc, nucleus accumbens; RL, reversal learning; PAL, paired-associate learning; rPAL, rodent paired-associate learning; dPAL, different paired-associate learning; SPAL, same paired associate learning; delayed response task; DAAO, Damino acid oxidase; TUNL, trial-unique, delayed non-matching-to-location; CANTAB, Cambridge Neuropsychological Test Automated Battery; SD, signal detection task; PVBC, PV-containing GABAergic basket cells; PING, Pyramidal-Interneuron Network Gamma; AMPAR, $\alpha$-amino-3-hydroxy5-methyl-4-isoxazolepropionic acid receptor, PET, positron emission tomography; MRI, magnetic resonance imaging; EEG, electroencephalogram. 


\section{Introduction}

Antipsychotic drugs alleviate certain psychotic symptoms of schizophrenia however, cognitive deficit and negative symptoms remain an unmet clinical need (Keefe et al., 2007). In spite of significant efforts by the Pharmaceutical Industry and academic groups, no drug has yet received a license for these indications (see Talpos, 2017 for recent review). Several key issues remain unresolved, for example, the failure of positive results with new drug candidates in preclinical to Phase II clinical trials to translate into success in large Phase III trials (Bespalov et al., 2016) and understanding the impact of long-term antipsychotic drug treatment on brain structure and function (Ho et al., 2011 and Vernon et al., 2014). Recent work by Carol Tamminga and colleagues has identified subgroups of patients according to brain based biomarkers not in accordance with their clinical diagnoses of schizophrenia, schizoaffective and bipolar disorder (Clementz et al., 2016). The authors suggest that these subtypes of patients are likely to benefit from differential treatment strategies. The key to development of improved therapies is improved animal models that mimic the human condition in terms of behaviour and pathology and that can reliably predict efficacy of novel treatments in patients. One of the benefits of animal work is development of different models that can represent these distinct clinical biotypes, and assess the therapeutic potential of novel and most appropriate treatments for each of these. We suggest that a model used routinely by us and others represents one of the biotypes identified by Tamminga and colleagues, those patients with poorest cognitive function and impaired response to sensory stimuli, i.e. biotype 1. Long-standing research in our laboratory shows that sub-chronic treatment $(2 \mathrm{mg} / \mathrm{kg}$ i.p. twice daily for 7 days followed by 7 days wash-out) with the un-competitive NMDAR antagonist PCP (Phencyclidine) mimics cognitive and negative deficit symptoms associated with schizophrenia in female Lister Hooded rats, and produces associated pathological changes, such as reduced expression of the calcium binding protein, parvalbumin (PV) in prefrontal cortex (PFC) and hippocampus (Neill et al., 2010; Neill et al., 2014). The behavioural effects are attenuated by atypical antipsychotics, specifically low dose risperidone and novel targets but not by classical antipsychotics, and the PV deficits by a novel treatment currently under development. In our 2010 review (Neill et al., 2010) we extensively reviewed deficits produced by NMDAR antagonists in tests for domains of cognition affected in schizophrenia, i.e. attention, executive function, visual recognition memory, and problem solving in addition to effects on social behaviour and neuropathology. We also discussed the validity of this model and its ability to detect promising new drug candidates for cognitive impairment associated with schizophrenia (CIAS). In 2014 we followed up this review with analysis of effects of NMDAR antagonism in tests for negative symptoms, specifically social behaviour and anhedonia. Most recently we have shown effects of our sub-chronic PCP (SCPCP) dosing regimen in tests for affective and optimistic bias, measures of affective state in animals of relevance to negative symptoms in patients (Sahin et al., 2016). In 2016 we briefly reviewed the work that led to establishment of the model in our laboratory and subsequent work with PV in PFC and hippocampus as a marker for cognitive deficits induced by NMDAR antagonism (Reynolds and Neill, 2016). The aim of the current review is to provide an update on work with NMDAR antagonist models for CIAS in animals, and evaluation of novel drug candidates using these techniques, Figure 1 . This update describes studies published since our original review in 2010. We also include a new section on gamma oscillations and NMDAR antagonism, of considerable importance for mediating cognitive function in patients and animals. There have been significant recent advances in our understanding of their importance and modelling of these in animals both in vitro and in vivo, providing a valuable opportunity to understand the 
mechanisms by which novel compounds restore cognitive function in the animal models and potentially in patients. Citation analysis through web of science for our 2010 publication reveals 229 citations, excluding self-citations. Analysis by year shows an average of 28.62 citations per year with 30-39 per year in 2013-2015, 50 in 2016 and 18 so far in 2017. This demonstrates a steady rate of citation with no evidence for reduced interest in this mechanism over time. It is quite revealing that an increase in citations was observed in 2016, as long ago as 6 years after the original publication and that this work is still being cited today. Here we examine deficits produced by NMDAR antagonists in several tests assessing different domains of cognition affected in schizophrenia in rodents: novel object recognition for visual recognition memory, operant tasks for spatial working memory, visual learning and memory, attention, problem solving and attentional set shifting for executive function. It is important to distinguish between the animal model which is NMDAR antagonism and the tests which assess cognitive deficits induced by the model and their restoration by novel drug targets. We include acute and sub-chronic dosing regimes of NMDAR antagonists, however it is important to point out that acute effects of NMDAR antagonists and the drugs being evaluated, and their potential interaction can compromise results obtained with acute models. In this respect, we recommend a sub-chronic dosing regimen followed by a wash out period to avoid this confound, as discussed in Neill et al. 2016. We also include a section on pathology and on gamma oscillations, see Figure 1 for overview.

\section{FIG 1 HERE}

\section{Novel object recognition (NOR)}

The novel object recognition (NOR) test in rodents is a non-rewarded, ethologically relevant paradigm based on spontaneous exploratory behaviour in rodents (Ennaceur and Delacour, 1988) widely used to model human declarative memory (Ennaceur, 2010). A comprehensive PubMed search on the NOR test applied in rodents retrieves 1649 papers, 1168 of which have been published since our extensive review in 2010 (Neill et al., 2010). This search result indicates that the potential of NOR for testing memory impairment has been increasingly recognized since then and that this test has emerged as one of the most widely used for assessing non-spatial short-term memory in rodents. There are several reasons for its popularity. It is a quick and simple test not requiring any complex equipment or lengthy training which gives it a significant advantage over other methods. It is based on animals' innate preference for novelty therefore it does not require enhanced motivation, reward or punishment, reducing stress for the animals. In 2015 we published an indepth analysis of the use of this task for assessing cognitive deficits across a variety of central nervous system (CNS) disorders (Grayson et al., 2015).

Briefly, the NOR paradigm consists of two trials performed after the animal has been habituated to the testing arena. In the first trial, known as the acquisition phase, the animal is introduced to the testing arena which contains two identical objects for a brief period of time (3-10 min). After an inter-trial interval (ITI) that can range from 1 minute to 24 or more hours, the animal is exposed to a copy of the familiar object from the first trial and a novel object. This is called the retention trial. Animals with no cognitive impairment explore the novel object for longer compared to the familiar object. Its application enables the study of various behavioural features associated with neuropsychiatric disorders, such as the process of recognition memory, and the role of different 
brain regions in the process of storage, consolidation and retrieval of recognition memory (Dere et al., 2007).

There is extensive evidence, summarized in our review in 2010 (Neill et al., 2010) and most recently in Rajagopal et al. (Rajagopal et al., 2014), that systemic administration of NMDAR non-competitive antagonists, such as PCP, MK-801and ketamine induces enduring impairment in the retention trial of the NOR task. NMDAR hypofunction in rodents is the most widely used model for the study of visual memory deficits associated with schizophrenia. According to our search results, 51 articles out of 1571 have been published on object recognition impairment in PCP treated rodents, 30 on ketamine and 44 on MK-801. The NMDAR antagonist model may provide a useful tool for the development of novel treatments to restore recognition memory deficits associated with schizophrenia, and other disorders where cognitive deficits are produced by cortical disinhibition.

Rajagopal et al., in 2014 reviewed various molecular targets for their potential to alleviate CIAS through their efficacy to ameliorate sub-chronic NMDAR (scNMDAR)-induced deficits in NOR. These are varied and include; dopamine $D_{1}$ receptors, nicotinic and muscarinic acetylcholine receptors, glutamate receptors, various serotonin receptor subtypes, and $y$-aminobutyric acid (GABA) receptors. According to their analysis, $\mathrm{D}_{1}, 5-\mathrm{HT}_{1 \mathrm{~A}}$ and $\mathrm{GABA}_{\mathrm{A}}$ agonists or partial agonists, $5-\mathrm{HT}_{6}, 5-$ $\mathrm{HT}_{7}$, and $\mathrm{D}_{3}$ antagonist, and $\alpha 7$ nicotinic receptor agonists appear to be the most promising receptor ligands. Here we will not repeat this analysis and instead we refer the reader to that review, but we will consider the most recent, not yet reviewed, receptor-selective ligands found to restore the NOR deficit induced by scNMDAR antagonist treatment (see Table 1 for full details of these studies which are summarised in the text below).

Nicotinic acetylcholine receptors (nAChRs) have been shown to play a role in learning and memory (Levin et al., 2006). Particularly agonists of the $\alpha 7$ and $\alpha 4 \beta 2$ nAChRs - the most prevalent subtypes in the brain - enhance cognitive performance in several animal models (Leiser et al., 2009). For an example, see our most recent work with encenicline, the $\alpha 7 \mathrm{nAChR}$ partial agonist that recently failed in a Phase III clinical trial for cognition in schizophrenia (http://www.businesswire.com/news/home/20160324006003/en/FORUM-Pharmaceuticals-UpdateEncenicline-Phase-3-Clinical), to improve attention and vigilance in low attentive rats (Hayward et al., 2017). Acute treatment with selective $\alpha 7$ nAChR partial agonists, SSR180711 (Pichat et al., 2007), and WYE-103914 (Ghiron et al., 2010) have been shown to reverse MK-801-induced NOR deficits in rats. Sub-chronic administration of SSR180711 also significantly improved a chronic intermittent PCP-induced NOR deficit in mice (Hashimoto et al., 2008). Work conducted in our laboratory has shown that the selective $\alpha 7$ nAChR full agonist, PNU-282987, reversed the scPCP-induced NOR deficit in female Lister Hooded rats (McLean et al., 2011). Our finding has been confirmed in a recent study where the NOR deficit following SCPCP treatment was reversed by both selective $\alpha 7 \mathrm{nAChR}$ agonism (with PNU-282987) and $\alpha 4 \beta 2$ nAChR agonism (with A-85380) (Miyauchi et al., 2016). These effects were antagonised by pre-treatment with MLA and $D H \beta E$, selective antagonists of $\alpha 7$ and $\alpha 4 \beta 2 \mathrm{nAChRs}$ respectively, supporting a role for these receptors in the reversal of the SCPCP-induced deficits in NOR.

In recent years, there have been significant advances in the development of novel ligands that act at allosteric sites to regulate receptor function, the so called positive allosteric modulators (PAMs). 
These compounds modulate the activity of the target when the endogenous ligand is bound concurrently thereby preserving normal physiological signalling patterns. PAMs of $\alpha 7-n A C h R s, P N U-$ 120596 and CCMI, and galantamine, an acetylcholinesterase inhibitor (AChE) that also allosterically modulates nAChRs, reverse the NOR impairment in ketamine treated rats. The efficacy of $\alpha 7$ PAMs in NOR has been compared to the orthosteric agonist A-582941 (Nikiforuk et al., 2016b). Another novel $\alpha 7-n A C h R$ PAM, Lu AF58801, showed efficacy in restoring the NOR deficit in scPCP-treated rats (Eskildsen et al., 2014). The neuronal mechanisms underlying the positive effects of $\alpha 7$-nAchR agents are still under investigation. There is some evidence to suggest that they contribute to restoration of the gamma oscillation disturbance induced by NMDAR blockade (Song et al., 2005; Thomsen et al., 2009).

Selective serotonin (5-HT) receptor drugs represent another class of promising cognition enhancing agents for schizophrenia and other disorders. The efficacy of atypical antipsychotic drugs (AAPDs), compared with classical APDs, in reversing the NMDAR antagonist NOR deficit is thought to be explained by their greater affinity for $5-\mathrm{HT}_{2 \mathrm{~A}}$ over the dopamine $\mathrm{D}_{2}$ receptor (Meltzer et al., 2013). Often $5-\mathrm{HT}$ agonism or antagonism contributes to the ability of antipsychotics at sub- $\mathrm{D}_{2}$ blocking doses to ameliorate cognitive impairments and negative symptoms in schizophrenia (Meltzer et al., 2013). Of the 5-HT receptor family, $5-\mathrm{HT}_{1 \mathrm{~A}}, 5-\mathrm{HT}_{6}$ and $5-\mathrm{HT}_{7}$ receptor antagonism, appear to be the most promising in restoring the object recognition impairment in SCNMDAR antagonist rodent models (Meltzer et al., 2013; Rajagopal et al., 2014). Asenapine is a multireceptor antagonist with relatively high binding affinity for $5-\mathrm{HT}_{2 \mathrm{~A}}, 5-\mathrm{HT}_{2}, 5-\mathrm{HT}_{6}, 5-\mathrm{HT}_{7}, \alpha_{2 B}, \mathrm{D}_{3}, \mathrm{D}_{2}, \mathrm{D}_{1}$ or $5-\mathrm{HT}_{1 \mathrm{~A}}$ receptors (Shahid et al., 2009). Acute treatment with asenapine reversed SCPCP-induced deficits in NOR in a dose-related manner. This effect was antagonised by the $\mathrm{D}_{1}$ receptor antagonist $\mathrm{SCH}-23390$, but not by the $5-\mathrm{HT}_{1 \mathrm{~A}}$ receptor antagonist WAY100635. These results thus suggest that $\mathrm{D}_{1}$ but not $5-\mathrm{HT}_{1 \mathrm{~A}}$ receptor mediated mechanisms regulate the asenapine recognition memory restoration effect (Snigdha et al., 2011a). Lurasidone is a novel antipsychotic, recently licensed for treating schizophrenia, with $5-\mathrm{HT}_{2 \mathrm{~A}}, 5-\mathrm{HT}_{7}, \mathrm{D}_{2}$ antagonist, and $5-\mathrm{HT}_{1 \mathrm{~A}}$ receptor partial agonist properties, with negligible affinity for nAChRs or muscarinic acetylcholine receptors (mAChRs) (Ishibashi et al., 2010). Acute treatment with lurasidone ameliorates and prevents the SCPCP-induced NOR deficit (Horiguchi and Meltzer, 2012; Horiguchi et al., 2012). In contrast to asenapine, the preventative effect of lurasidone was attenuated by WAY100635, demonstrating the involvement of $5-\mathrm{HT}_{1 \mathrm{~A}}$ agonism in the cognition-enhancing effect of lurasidone (Horiguchi et al., 2012). In a mechanistic study, lurasidone was tested in combination with $\mathrm{nAChR} \alpha 7$ and $\alpha 4 \beta 2$ agonists showing that, while $\mathrm{nAChR}$ agonism is not necessary for lurasidone to restore the SCPCP-induced NOR deficit, the combined treatment with $\alpha 7$ and $\alpha 4 \beta 2$ agonists potentiated lurasidone's efficacy in this model. Indeed lurasidone at a subeffective dose restored the deficit when co-administrated with a sub-effective dose of $\alpha 7$ and $\alpha 4 \beta 2$ agonists (Miyauchi et al., 2016). Lurasidone, in a dose range of 40-160 mg/day, has demonstrated efficacy in the treatment of patients diagnosed with schizophrenia. It appears to be associated with minimal effects on body weight gain, and low risk for clinically meaningful alterations in glucose, lipids, or electrocardiographic parameters. Most importantly for this review is that, in two randomized trials, lurasidone demonstrated improvement in functional capacity and cognitive functioning in people with schizophrenia, supporting its therapeutic potential in the treatment of this neuropsychiatric disorder and translational relevance of the positive preclinical data described above (Harvey, 2015). Finally, the least studied of the serotonin receptor family to date, the $5-\mathrm{HT}_{5 \mathrm{~A}}$ receptor, also demonstrated a potential role in ameliorating cognitive deficits in schizophrenia. The 
5- $\mathrm{HT}_{5 \mathrm{~A}}$ receptor antagonist SB-699551 reversed NOR deficits in an acute ketamine model (Nikiforuk et al., 2016a).

Alterations in neural circuitry involving the inhibitory neurotransmitter, GABA, have been associated with cognitive deficits, see section 5 of this review (Liu et al., 2009; Tamminga, 2006). We have shown that SCPCP treatment reduces parvalbumin expression in GABAergic interneurons in the frontal cortex, dentate gyrus and the CA2/3 region of the hippocampus (Abdul-Monim et al., 2007, see commentary by Reynolds and Neill, 2016). We have demonstrated that gaboxadol, a functionally selective extrasynaptic $G A B A_{A}$ receptor agonist, and AA29504, a positive modulator of extrasynaptic $G_{A B A_{A}}$ receptors, alleviated a SCPCP-induced deficit in the NOR (Damgaard et al., 2011). A combination of these compounds at sub-effective doses also restored the SCPCP-induced NOR deficit (Damgaard et al., 2011). There is emerging evidence from animal models for schizophrenia that allosteric modulation of the $\alpha 5$ subunit of the $G_{A B A}$ receptor has a potential in ameliorating cognitive deficits (Gill and Grace, 2014). The $\alpha 5$-selective inverse agonist, R04938581 attenuated NOR deficits in rats induced by SCPCP (Redrobe et al., 2012). PWZ-029, a partial inverse agonist selective for $\alpha 5$-containing $\mathrm{GABA}_{\mathrm{A}}$ receptors also reversed MK-801-induced NOR deficits in in rats (Timic Stamenic et al., 2015).

A standard approach in the treatment of schizophrenia is to restore abnormal dopamine neurotransmission. The classical dopamine-antagonist APDs have high affinity for the $D_{2}$ family of dopamine receptors and are effective in treating positive symptoms but have little effect on negative symptoms or the cognitive impairment. AAPDs, on the contrary, have been reported to have small effects to improve cognitive function in certain patient groups. The AAPDs show a lower affinity for $D_{2}$ receptors, yet readily bind to $D_{3}$ and $D_{4}$ receptors. $D_{4}$ receptors are expressed in brain areas mediating cognition, such as PFC and hippocampus. They are highly expressed in GABAergic PV-expressing interneurons (de Almeida and Mengod, 2010), reduced by NMDAR antagonists and in the illness (Abdul-Monim et al., 2007; Lewis, 2014; Li et al., 2016). Although certain $D_{4}$ receptor antagonists, like L-745,870 and sonepiprazole, failed in clinical trials (Corrigan et al., 2004; Kramer et al., 1997), interest in exploring the involvement of $D_{4}$ receptors in cognitive function has recently increased. Certain AAPDs such as clozapine are potent $\mathrm{D}_{4}$ receptor antagonists (Seeman and Van Tol, 1994; Wong and Van Tol, 2003). As confirmation of the $D_{4}$ receptor as a potential therapeutic target for cognitive impairments there is evidence that report the ability of D4 agonists in improving social recognition and cognitive performance in rats (Bernaerts and Tirelli, 2003; Browman et al., 2005; Woolley et al., 2008;). We investigated the effects of a potent $\mathrm{D}_{4}$ receptor agonist, PD168077 (N(Methyl-4-(2-cyanophenyl)) piperazinyl-3-methylbenzamide) on cognitive function in the NOR task in rats. This drug has a 400 -fold selectivity for $D_{4}$ over $D_{2}$ receptors and greater than 300 -fold selectivity for $D_{4}$ over $D_{3}$ receptors (Glase et al., 1997). PD168077 dose-dependently reversed the ScPCP NOR deficit (Sood et al., 2011). Our results have been confirmed by a recent study where PD168077 restored the ScPCP-induced deficit in a dose-dependent manner (Miyauchi et al., 2017). Moreover Miyauchi and colleagues (2016) showed that co-administration of a sub-effective dose of PD168077 with a sub-effective dose of lurasidone, that has a negligible affinity for $D_{4}$ receptors, reversed the NOR deficit, while co-administration of a sub-effective dose of PD168077 and a sub-effective dose of clozapine, a potent $D_{4}$ antagonist, did not reverse the NOR impairment induced by scPCP. Patients treated with a potent $D_{4}$ antagonist may therefore not benefit by treatment with a $D_{4}$ receptor agonist for improving cognitive function. 
Cariprazine is a potent dopamine $D_{3} / D_{2}$ receptor partial agonist, recently approved by the FDA (https://www.fda.gov/newsevents/newsroom/pressannouncements/ucm463103.htm) with an in vivo higher affinity for $D_{3}$ over $D_{2}$ receptors. This pharmacological profile differs from currently marketed AAPDs. Compounds that selectively bind $D_{3}$ receptors (e.g. SB-277011, S33084) do not show an antipsychotic-like effect in animal models (Millan et al., 2000; Reavill et al., 2000), but selective $D_{3}$ receptor antagonists (e.g. the highly selective SB-277011 and RGH-1756, the moderately selective U-99194A and the selective partial $D_{3}$ agonist BP-897) enhance cognitive function in memory-impaired rodents (Joyce and Millan, 2005; Laszy et al., 2005). We have recently shown that acute administration of cariprazine significantly improved the SCPCP-induced NOR deficit (Neill et al., 2016). The mechanism of action remains to be determined but its high affinity for the dopamine $D_{3}$ receptor is likely to play a role. Any efficacy to restore cognitive function in patients will become clearer with further clinical evaluation.

Along with the classical receptor agonist/antagonist and PAM strategies, NOR can be exploited to test alternative approaches for restoring NMDAR antagonist-induced cognitive impairment. Nitric oxide (NO), a soluble, short-lived and freely diffusible gas, may play an important role in cognitive function (Prast and Philippu, 2001). Certain experimental evidence links altered production of NO with schizophrenia. Abnormal distribution of nitrergic neurons (Akbarian et al., 1993) and reduction of calcium-dependent NO synthase activity (Xing et al., 2002) have been reported in the brains of schizophrenia patients. Also, a reduction in metabolites in the serum of patients with schizophrenia has been shown (Ramirez et al., 2004; Lee and Kim, 2008). The ability of NO to restore recognition memory impaired by ketamine has been demonstrated in two separate studies. Kandratavicius and colleagues (2015) showed that treatment post-, but not prior to ketamine, with the (NO)-donor, sodium nitroprusside (SNP) restored long term memory (24 hr after ketamine injection) but not short-term memory ( $1 \mathrm{hr}$ after ketamine injection) deficits in the acute ketamine model (Kandratavicius et al., 2015). Trevlopoulou and colleagues (2016) showed that SNP (injected 5-10 min after ketamine when both were given post-acquisition) restored the deficits induced by ketamine in a short-term memory experiment ( $1 \mathrm{hr}$ ITI). The discrepancy in these 2 studies is likely explained by differences in the type of memory process being tested. In the first study SNP was administered before the acquisition phase, analysing the effect of SNP on the memory encoding process. In the second study SNP was administered after the acquisition trial, therefore testing the storage/retrieval process. This suggests that distinct memory processes may be differentially influenced by NO donors.

Few studies have investigated effects of plant extracts on NMDAR antagonist-induced NOR deficits. Crocins is the active constituent of Crocus sativus L., commonly known as saffron. Initial work showed that administration of extracts of $C$. sativus $L$., or its constituent crocins, reversed NOR impairment induced by the muscarinic antagonist, scopolamine (Pitsikas and Sakellaridis, 2006; Pitsikas et al., 2007). More recently, crocins has been successfully tested in ketamine-treated rats in NOR. A post-acquisition NOR phase administration of crocins reversed the ketamine-induced recognition memory deficit (Georgiadou et al., 2014). As with NO, this suggests an effect on memory consolidation.

NMDAR hypofunction is reported to reduce the fast-spiking properties of a subtype of GABA interneurons, the PV containing cells (Lewis, 2014; Lisman et al., 2008)). Potassium voltage gated ion 
channels Kv3.1 and Kv3.2 are typically expressed on those interneurons and are necessary for their fast-spiking phenotype. Analysis of mRNA expression has shown a reduction in Kv3.1 channels in post-mortem brains of patients with schizophrenia (Yanagi et al., 2013) and in a PCP rat model for schizophrenia (Pratt et al., 2008). We have consistently shown the efficacy of a novel and selective Kv3.1/3.2 channel modulator, AUT00206, to improve the NOR deficit in SCPCP treated rats (Leger et al., 2015; Cadinu et al., 2016). We have been working extensively on this new target for schizophrenia over the past 5 years and demonstrated many other effects in our SCPCP model including reversal of the extradimensional shift (EDS) deficit in the attentional set-shifting task (ASST) (Cadinu et al., 2016) see section on ASST for further details. A Phase I clinical trial has been successfully completed with AUT00206 and an increase in mismatch negativity in a small number of healthy volunteers was observed. A ketamine imaging experimental medicine study is currently underway and most recently a small study in schizophrenia patients has been initiated. It remains to be determined whether the positive preclinical results will translate into efficacy in the clinic, but the extensive preclinical evaluation certainly supports the hypothesis of efficacy at least in a subset of patients (Clementz et al., 2016).

Recent work has focused on understanding the neural mechanisms underlying the NOR deficit observed in NMDAR antagonist rodent models. Our laboratory and others use a short ITI (1 min) consistent with involvement of the medial prefrontal cortex (MPFC) in recognition memory (Grayson et al., 2007; Snigdha et al., 2011b; Young et al., 2015). Asif-Malik and colleagues (2017) in an in vivo electrophysiology study, observed an increase in neuronal firing in the MPFC and in the nucleus accumbens (NAC) shell during exploration of the novel object in vehicle-treated animals (following a $1 \mathrm{~min}$ (TI), showing involvement of these brain structures in the novelty response. The same increase in mPFC and NAc neuronal activity was not seen in SCPCP-treated animals (Asif-Malik et al., 2017). This provides an important explanation for the cognitive deficits in SCPCP treated animals and a possible target for drug action. This is consistent with our recent in vivo microdialysis work (McLean et al., 2017) in which we observed that vehicle and SCPCP-treated rats have the same PFC dopamine basal levels and the same PFC dopamine concentration throughout the 10 min habituation phase, the $10 \mathrm{~min}$ acquisition trial and during the $10 \mathrm{~min}$ ITI. During the $10 \mathrm{~min}$ retention trial, however, vehicle-treated rats show an increase in dopamine levels in the PFC, compared to the basal level, which was abolished by SCPCP treatment. These studies demonstrated that an increase in mPFC dopamine activity is necessary for successful recall of information about the familiar object and in the discrimination of novelty from familiarity.

\section{TABLE 1 HERE}

In summary, administration of NMDAR antagonists (PCP, ketamine, MK-801) consistently produces a deficit in the NOR task. This is demonstrated by the large number of publications reporting object recognition memory impairment in animal models using NMDAR blockade, even since our initial review in 2010. This confirms NOR as a reliable means to investigate mechanisms of learning and memory of relevance to psychiatric disorders as described above. Furthermore, through administration of the drug under investigation at various stages of the task, effects on memory acquisition, consolidation and retrieval may be investigated. NMDAR antagonist-induced deficits are an invaluable tool for assessing the efficacy of novel pharmacological agents to improve CIAS. However of course this should be just the first step in a series of animal studies designed to explore 
efficacy of the novel agent to restore CIAS in a range of tests for the domains of cognition affected. Other studies should also include investigation in the presence of APDs, confirmation of target engagement, and mechanistic evaluation using techniques such as in vitro and in vivo electrophysiology, microdialysis, and post-mortem work as described in this article. Further analysis should also be conducted in other animal models incorporating genetic and neurodevelopmental components e.g. using a maternal immune activation approach (see Knuesel et al., 2014 for review).

\section{Attentional set-shifting (ASST)}

The perceptual attentional set-shifting task (ASST) investigates the ability of a rodent to learn a rule and form an attentional set within the same sorting category, intra-dimensional shift (IDS), as well as the ability to shift attentional set between different sorting categories, extra-dimensional shift (EDS) (Birrell and Brown, 2000). It represents a rat analogue of the human CANTAB ID/ED task (Downes et al., 1989) in which schizophrenia patients exhibit impaired set-shifting and reduced cognitive flexibility (Berg, 1948; Pantelis et al., 1999; Tyson et al., 2004). Indeed we have demonstrated EDS deficits in a small cohort of 1st episode south Asian patients (Saleem et al., 2013). This task recruits the medial frontal cortex for successful completion (Birrell and Brown, 2000) functionally similar to the PFC in primates and we and others show reduced PFC function in NMDAR antagonist models (see other sections of this review for an update). ASST has been identified as being of particular translational relevance in the search for new pharmacotherapy for CIAS (Goetghebeur and Dias, 2014). Indeed we use this task routinely in our laboratory, to identify efficacy of novel drug targets to improve executive function in our scPCP model. We previously reviewed work with this task in Neill et al., 2010. In this section we will describe studies conducted since that time, by us and others using NMDAR antagonists to induce an EDS deficit in this task. NMDA receptors have been suggested to play an important role in cognitive flexibility. Specifically, NMDAR hypofunction in cortical regions has been implicated in flexibility impairments (Darrah et al., 2008).

We have consistently shown a selective deficit in the EDS phase in adult female Lister hooded rats in our scPCP model. Selectivity for the EDS phase is shown by patients and supports the translational relevance of the test. In this test the subject uses stimuli to guide correct behaviour or choices ie one stimulus (media or odour in the rodent version, shapes and lines in the human version) predicts the reward, the other is non-rewarded. In the EDS phase, the stimulus guiding behaviour is swapped for the one that was previously ignored. This is the hardest part of the task requiring activation of the PFC and considerable cognitive flexibility. This aspect of the task is impaired in patients with frontocortical pathology and in rodent models for schizophrenia such as NMDAR antagonist models, and, in our hands, in a maternal immune activation model (Grayson et al. 2017) where we also observe reduced PV expression in PFC (unpublished data). Our sCPCP-induced deficit was reversed by acute treatment with a positive allosteric modulator of $\alpha 7$ nicotinic acetylcholine receptors, PNU120596 (10 mg/kg, s.c.) (McLean et al., 2012) and more recently by TAK-063, a phosphodiesterase $10 \mathrm{~A}$ inhibitor under development for CIAS by Takeda, at $0.3 \mathrm{mg} / \mathrm{kg}$ given acutely p.o. (Shiraishi et al., 2016). Most recently we have reversed the ScPCP-induced deficit with AUT00206. At $60 \mathrm{mg} / \mathrm{kg}$ p.o. AUT00206 selectively attenuated the SCPCP-induced deficit in EDS when given once daily over 14 days in vehicle and in haloperidol $(0.1 \mathrm{mg} / \mathrm{kg}$ p.o. once daily for 21 days)-treated female Lister Hooded rats (Cadinu et al., 2016). 
Administration of PCP via other routes, using different dosing regimens and in different sex and strain of rat has been shown to produce similar deficits in performance of the ASST. For instance, subcutaneous implantation of osmotic mini-pumps containing PCP $(15 \mathrm{mg} / \mathrm{kg} / \mathrm{day}$ for 14 days followed by 7 days washout) in adult male Lister Hooded rats induced a selective deficit in the EDS, that was rescued by the novel cognitive enhancer modafinil (64 mg/kg, p.o.) (Pedersen et al., 2009). Similarly, sCPCP treatment $(5 \mathrm{mg} / \mathrm{kg}$, i.p., b.i.d. for 7 days) and early post-natal PCP treatment (20 $\mathrm{mg} / \mathrm{kg}$, s.c., post-natal day 7, 9 and 11 ) in male Lister hooded rats induced deficits in performance of the ASST. The negative modulator of $\mathrm{GABA}_{\mathrm{A}} \alpha 5$ receptors $\mathrm{RO} 4938581$ (1 mg/kg, p.o.) attenuated both SCPCP- and neonatal-PCP-induced deficits in ASST (Redrobe et al., 2012).

Other NMDA receptor antagonists including ketamine and MK-801 have also been shown to induce similar deficits in ASST. Acute ketamine $(10 \mathrm{mg} / \mathrm{kg}$, s.c.) induced a selective deficit in the EDS in male Sprague-Dawley rats (Nikiforuk et al., 2010). The dopamine and noradrenaline reuptake inhibitor mazindol ( $5 \mathrm{mg} / \mathrm{kg}$, s.c.), the PAMs of $\alpha 7-n A C h R s, ~ P N U-120596$ (0.3 and $1 \mathrm{mg} / \mathrm{kg}$, i.p.) and CCMI (0.3 and $1 \mathrm{mg} / \mathrm{kg}$, i.p.), the acetylcholinesterase inhibitor (AChE) that also allosterically modulates nAChRs, galantamine ( $3 \mathrm{mg} / \mathrm{kg}$, i.p.), the orthosteric $\alpha 7-n A C h R$ agonist A-582941 $(0.3$ and $3 \mathrm{mg} / \mathrm{kg}$, i.p.) and the $5-\mathrm{HT}_{5 \mathrm{~A}}$ receptor antagonist $\mathrm{SB}-699551(0.3,1$ and $3 \mathrm{mg} / \mathrm{kg}$, i.p.) significantly reversed the acute ketamine-induced impairment in the ASST task (Nikiforuk et al., 2010; Nikiforuk et al., 2016a: Nikiforuk et al., 2016b). While sub-chronic administration of ketamine (30 mg/kg i.p., twice daily for 5 days, followed by 10 days washout) did not impair set-shifting ability in male Long-Evans rats, similar treatment for 10 days (30 mg/kg i.p., followed by 14 days washout) did induce a selective deficit in the EDS in male Sprague-Dawley rats (Nikiforuk and Popik, 2012). This deficit was reversed by acute treatment with the AAPDs, sertindole $(2.5 \mathrm{mg} / \mathrm{kg}, \mathrm{p.o}$.) and quetiapine (1.25 and $2.5 \mathrm{mg} / \mathrm{kg}$, p.o.) (Nikiforuk and Popik, 2012). A recent study showed that both acute ( $20 \mathrm{mg} / \mathrm{kg}$, i.p.) and sub-chronic administration of ketamine $(20 \mathrm{mg} / \mathrm{kg}$, i.p. for 7 days followed by 7 days washout when clozapine was given for 7 days) in male C57BI/6J mice increased the number of trials and errors to reach criterion in the EDS phase. Both the acute and sc-ketamine-induced set-shifting deficits were restored by acute $(0.3 \mathrm{mg} / \mathrm{kg}$, i.p. $)$ and sub-chronic $(0.3 \mathrm{mg} / \mathrm{kg}$, i.p. for 7 days $)$ clozapine while the higher dose, of $1 \mathrm{mg} / \mathrm{kg}$, impaired performance in ketamine-treated mice (Szlachta et al., 2017). Administration of ketamine has also been used to induce neurodevelopmental disturbances of relevance to schizophrenia in mice. Ketamine treatment (30 mg/kg, s.c.) at PND 7, 9 and 11 impaired the ability of mice to discriminate the relevant stimulus within an extra-dimensional attentional set accompanied by a reduction in PV expression in the PFC in adult male noncarrier/wild type of the G42 line mice (Jeevakumar et al., 2015). Acute injection of MK-801 (0.1 and $0.3 \mathrm{mg} / \mathrm{kg}$, i.p.) induced a deficit in set shifting in male Sprague Dawley rats (Jones et al., 2014). This deficit was reversed by clozapine as well as by several $\alpha 7-n A C h R$ receptor agonists (SSR180711, PNU-282987, GTS-21).

An interesting study carried out by Gastambide and colleagues (2013) compared the effects of acute treatment with PCP (2.5 mg/kg, s.c., 120 min prior to testing) and ketamine $(10 \mathrm{mg} / \mathrm{kg}$, s.c., $60 \mathrm{~min}$ prior to testing) in the ASST in male Sprague-Dawley rats (age and weight not shown). Vehicle treated rats required significantly more trials to reach criterion in the EDS phase compared to the IDS phase, demonstrating that the rats had formed an attentional set towards the relevant stimulus dimension prior to the EDS phase. Rats treated with ketamine were selectively impaired in their ability to shift attentional set i.e. had increased trials to criterion in the EDS phase. Ketamine treated 
rats were not impaired in any other stage of the task. In contrast to ketamine's selective effect, PCP treated rats increased the number of trials to reach criterion in reversal 1 phase, reversal 2 phase and the EDS phase of the task. PCP induced a more widespread effect in the ASST compared to ketamine however acute effects of PCP not related to cognitive control may very well explain these effects, compared to the selective effect to impair performance in the EDS phase following a SCPCP treatment regimen (Neill et al., 2010; Mc Lean et al., 2012; Cadinu et al., 2016; Shiraishi et al., 2016).

The ASST has also been used to assess executive function following ketamine treatment in mice (Kos et al., 2011). In this study the effects of the NR2B-subtype specific antagonist Ro 25-6981 (3 and 10 $\mathrm{mg} / \mathrm{kg}$, i.p.) and the antipsychotic sertindole $(2.5 \mathrm{mg} / \mathrm{kg}$, p.o.) were assessed for their ability to improve an acute ketamine-induced (10 mg/ $\mathrm{kg}$, i.p) ASST deficit in adult (7-8 weeks old) male C57B1/6J mice. In this study, the ASST was divided into two sessions (session 1 and session 2), over two consecutive days, since the mice appeared to be satiated when all the phases of the task were carried out in one day. Indeed this is a significant disadvantage to using mice in this test rather than rats. Ketamine, given $120 \mathrm{~min}$ prior to session 1 and $50 \mathrm{~min}$ prior to session 2 impaired EDS performance. Acute sertindole attenuated this ketamine-induced impairment. In contrast to ketamine, Ro 25-6981 did not impair performance in this test, indeed this compound at $10 \mathrm{mg} / \mathrm{kg}$, reduced the number of trials and errors to criterion in the EDS and also attenuated the ketamineinduced impairment in the EDS phase suggesting a facilitation of cognitive flexibility. This study provides an ASST protocol for use in mice and confirms previous findings that NR2B subunit selective antagonists can improve cognitive function (Higgins et al. 2005). Several compounds discussed in this review (SSR180711, PNU-120596, galantamine, SB-699551) are effective in NOR and ASST indicating their ability in attenuating both the visual memory impairment and reduced cognitive flexibility.

In summary, analysis of ASST NMDAR antagonist studies published since our review in 2010 reveals a consistent ability of NMDAR antagonists to impair cognitive flexibility in rodents as measured in the ASST, supporting the glutamatergic hypofunction hypothesis of CIAS. Most studies use either ketamine or PCP in adult male rats. We use females for our work for a variety of reasons that we have discussed several times (e.g. see Grayson et al., 2016 and Neill et al., 2016). It is very important to note that subjects of both sexes/gender should be used in preclinical and clinical research and that the current unfortunate reliance on males of the species is bad science (Clayton and Collins, 2014). This work demonstrates the importance of assessing cognitive flexibility using this task, albeit much more complex and time consuming to run than e.g. NOR. From the number of papers published on ASST compared with NOR however, it is clear that this task is not used anything like as frequently, presumably for this reason. In our hands it take at least 6 weeks to test a pharmacological agent in this task, testing 2-3 rats per day, assessing 3 doses of a new drug plus a positive control, compared with 2-3 days in NOR. The observation that scientists are prepared to take 6 weeks to run this task however is clear evidence of its importance and value in this field. In terms of the principles of Replacement, Reduction and Refinement-NC3Rs (www.nc3rs.org.uk/the$3 \mathrm{rs}$ ) we do not routinely re-test animals in this paradigm however, this is successfully conducted by the scientists who developed the rodent version used by so many laboratories (Brown, personal communication). However, we do routinely test the same animals in this task, in NOR and in social interaction, demonstrate a reliable deficit in each and are committed to the principles of the 3Rs.

\section{Operant tests}


There are certain advantages to using operant tasks in rodents compared with more ethologically relevant tests such as NOR and ASST. These tasks are readily automated, reducing experimental variability as there is less influence of individual experimenter on the task, each parameter set for an individual animal is identical on every trial therefore increasing accuracy; large numbers of animals can be tested simultaneously which in turn generates large amounts of data. Operant tasks are generally based upon appetitive reward rather than aversive stressors which are known to have detrimental effects on cognition function. Another important advantage of using operant techniques to assess cognition in rodents is that different domains of cognition can be assessed with advanced technology now available eg touchscreens. Inter-laboratory comparison of data is facilitated by use of the same apparatus and computer programmes and behaviours are recorded by computer enabling larger amounts of information to be analysed quickly. Of course there are disadvantages to operant techniques. Behavioural effects may be missed that are readily picked up when experimenters score behaviour from recordings and watching animals in situ enables enhanced interpretation of behavioural changes. The operant environment is much less amenable to adjustments to suit the experimental design, experimenter and the animal. The benefits of taking an ethological approach have of course been discussed elsewhere (e.g. see Peters et al., 2015) and we recommend a combination of both types of testing procedure. Furthermore, many different types of food reward are used and task performance can be affected by the nature of the reinforcer such as nutritional value, palatability, taste and whether the reward is a solid or a liquid (Kim et al., 2017). A disadvantage of using appetitive rewards is the frequent use of food deprivation, usually to about $85 \%$ of free-feeding bodyweight, which itself is known to increase serum corticosterone levels (Nowland et al., 2011) and alter brain chemistry (Branch et al., 2013), which have direct negative impact on learning and cognition. Of course refinement of these techniques using highly palatable food rewards such as chocolate or banana flavoured pellets and milkshake can reduce the need for food deprivation and enhance animal welfare. Another drawback of using operant techniques is the lengthy training times required to establish stable baseline behaviour which impacts heavily on costs incurred for housing the animals and staff time during this period. In addition operant techniques tend to rely on procedural memory which limits their use for studying different cognitive processes.

The operant tasks described in this section have been used to study impairments induced by NMDAR antagonists across several domains of cognition affected in schizophrenia, we start by explaining the nature of each particular test used and continue with its use in this field. Experimental details are shown in Table 2.

\section{$\underline{4.1 \text { Reversal learning-RL }}$}

A reversal learning (RL) task extensively used in our laboratory with standard operant chambers comprises two distinct components, an initial phase that requires memory of a previously learned reward contingency, followed by a reversal phase, in which the reward contingency is then reversed. Animals are required to inhibit a previously rewarded strategy and acquire the new strategy. Thus, effective performance requires animals to demonstrate flexibility, attention and motivation, to suppress a previously learned response and implement a new response (Jones et al., 1991). Failure to switch, or perseveration of the previously learned response, can be readily observed in patients with schizophrenia undertaking tasks such as the Wisconsin Card Sorting test (Pantelis et al., 1997; Liddle, 2000). We suggest that this type of paradigm could provide the basis for a rodent model in 
which to predict the ability of novel antipsychotic drugs to ameliorate aspects of executive dysfunction associated with schizophrenia. Indeed operant reversal learning measures executive function and is dependent on PFC function (McAlonan and Brown, 2003). Furthermore, the TURNS initiative has identified that reversal learning tasks, as with attentional set-shifting tasks can be used to investigate the problem solving deficits in the illness and are included in the Measurement and Treatment research to Improve cognition in schizophrenia (MATRICS) battery (www.turns.ucla.edu).

Operant studies performed in rats in our laboratory and reported by Large (2011) compared the efficacy of two new structurally diverse sodium channel blocker molecules GSK2 and GSK3 with the established sodium channel blocker, lamotrigine to prevent the cognitive deficit induced by acute treatment with PCP in our operant RL paradigm. Effects of these drugs to prevent brain activation and neurochemical effects of PCP were also explored. Rats were trained and tested in the operant RL paradigm as described previously by Idris and colleagues (2005). Briefly in the testing phase each session began with a 5 min period (initial phase) during which the reinforcement contingency matched that of the previous day's training session. Following the initial phase, the house light was turned off and a 2-min time-out began. After the time-out period, the house light was illuminated, and the next phase of the task started (reversal phase), during which the reinforcement contingency was reversed i.e. the visual cue (lit or un-lit) associated with reinforcement was switched. Acute administration of GSK2, GSK3 and lamotrigine prevented the deficit in RL produced by acute PCP, see table 2 for full experimental details. This study supports the evaluation of sodium channel blockers in the treatment of CIAS. We have also demonstrated efficacy of new antipsychotics, asenapine and cariprazine to restore operant RL deficits induced by SCPCP in rats (McLean et al., 2010; Neill et al., 2016).

Mice have been used to a lesser extent when studying cognition in operant tasks. However, based on rat operant reversal learning results with 5-HT receptor antagonists in the SCPCP model, from our laboratory (McLean et al. 2009a), Rajagopal and colleagues (2016) have recently studied the ability of $5-\mathrm{HT}_{1 \mathrm{~A}}$ agonism and $5-\mathrm{HT}_{7}$ receptor antagonism to improve a deficit in operant reversal learning in mice induced by sub-chronic treatment with PCP. SCPCP-treated mice had reduced percent correct responding in the reversal phase of the task, restored by acute treatment with the selective $5-\mathrm{HT}_{1 \mathrm{~A}}$ receptor partial agonist, tandospirone and by the selective $5-\mathrm{HT}_{7}$ receptor antagonist, SB269970, but not by the $5-\mathrm{HT}_{7}$ receptor agonist, AS 19. Pre-treatment with the new antipsychotic drug lurasidone, a $5-\mathrm{HT}_{1 \mathrm{~A}}$ partial agonist and $5-\mathrm{HT}_{7}$ antagonist, as well as a $5-\mathrm{HT}_{2 \mathrm{~A}}$ and dopamine $\mathrm{D}_{2}$ receptor antagonist, also reversed the RL deficit in ScPCP-treated mice. Furthermore, the selective $5-\mathrm{HT}_{1 \mathrm{~A}}$ receptor antagonist, WAY100635, blocked the ability of lurasidone to reverse the SCPCP-induced RL deficit. These results show that $5-\mathrm{HT}_{7}$ receptor antagonism and $5-\mathrm{HT}_{1 \mathrm{~A}}$ receptor partial agonism contribute to the improvement of RL deficits induced by SCPCP in mice, possibly by decreasing the excessive GABAergic inhibition of cortical pyramidal neurones following SCPCP treatment. Clinically, it is thought that this pharmacology of lurasidone will contribute to efficacy for CIAS, indeed initial clinical results look promising (Harvey, 2015).

$\mathrm{RL}$ can also be studied using the more recently developed rodent touchscreen operant apparatus. Fellini and colleagues (2014) compared the effects of acute PCP with SCPCP in adult rats in operant $\mathrm{RL}$ in a touchscreen box. Animals were trained to simultaneously perform two different visual discriminations. The reward contingency associated with one pair could be altered, whereas the second pair acted as an experimental control. This meant that the effect of a manipulation on RL, 
stimulus acquisition, or baseline responding could be more accurately evaluated through the use of a double visual discrimination. Acute, but not sub-chronic treatment with PCP, caused an impairment in $\mathrm{RL}$, an effect the authors report to be supported by unpublished findings demonstrating a lack of effect of sub-chronic ketamine in this task. The lack of effect of SCPCP treatment in this study does not support our findings of a robust deficit in RL in a 2 lever operant set up (Idris et al., 2010, Mclean et al., 2009a, 2009b, 2010, 2011). It is not clear why scPCP failed to induce a deficit in a touchscreen RL task, however this suggests that not all RL tasks are the same, and consideration of the processes necessary to perform a specific reversal task should be carefully considered.

\section{$\underline{4.2 \text { Paired associates learning-PAL }}$}

Visuospatial paired-associate learning (PAL) has been shown to be impaired in schizophrenia (Nuechterlein et al., 2004) and assesses visual learning and memory, a cognitive domain identified by the MATRICS. An automated touch screen PAL task for rodents requires learning that a particular object, i.e. one out of three symbols, is only correct in a particular location, i.e. usually one of three positions on the touchscreen. In the trial phase, two symbols are displayed, one in its correct, and another in an incorrect, position. The animal has to respond to the symbol in the correct position for reinforcement. There are two versions of the rodent PAL task (rPAL) which are referred to as dPAL and SPAL. In dPAL, there are three different stimuli presented in three different locations, two of which are presented together in a given trial. The other version is called SPAL and is identical to dPAL except that the two stimuli displayed in each trial are the same.

Recently Talpos and colleagues (2015) compared the effects of MK-801 and d-amphetamine in the PAL in rodents. PAL, as part of the CANTAB, measures visual memory and learning and has been suggested to be predictive of functional outcomes in first episode psychosis (Barnett et al, 2005, 2010). Talpos et al. (2015) developed an operant rodent object-in-place task (rPAL) whereby rats or mice are presented with 2 of 3 stimuli displayed in 2 of 3 possible locations. In their study, adult rats were first trained to complete the PAL task in an operant touchscreen chamber and then treated with acute MK-801 or d-amphetamine. Both d-amphetamine and MK-801 caused impairments in accuracy, MK-801 induced intense "perseverative" type behaviour more pronounced compared to $d-$ amphetamine. The d-amphetamine-induced deficits, but not those induced by MK-801, were reversed by acute treatment with haloperidol and risperidone as well as by the dopamine $D_{1}$ receptor antagonist $\mathrm{SCH}-23390$. These results may suggest that $\mathrm{d}$-amphetamine and $\mathrm{MK}-801$ provide dissociable models for impairment in PAL controlled by differential mechanisms which allow the study of the dopaminergic and glutamaterigic control of cognitive impairments in schizophrenia.

Lins and Howland have recently (2016) studied the effects of the metabotropic glutamate receptor 5 ( $\mathrm{mGluR}_{5}$ ) PAM CDPPB in the PAL touchscreen task in adult rats both alone and when disrupted by acute MK-801. In this study dPAL was used, three distinct black and white images, each having only one correct location out of three possible, rats had to learn to associate each image with its correct location. Correct selections were rewarded with a sugar pellet, incorrect selections were punished with a 5 s delay. CDPPB had no consistent effects on PAL performance when administered alone, it also failed to reverse the MK-801-induced impairments in PAL at all the doses tested demonstrating a lack of efficacy of increasing mGluR5 signalling in the PAL task. 
Earlier, the same researchers (Lins et al.,2015) examined the effects of acute treatment with D- and L- enantiomers of a tetrahydroprotoberberine agent, govadine, in comparison with haloperidol on MK-801-induced disruption of PAL in adult rats. Both enantiomers have high affinity for dopamine $D_{1}$ receptors and enhance dopamine efflux in the PFC (Lapish et al., 2014) however L-govadine differs from $D$-govadine in that it has greater affinity for dopamine $D_{2}$ receptors and uniquely increases dopamine efflux in the nucleus accumbens. In this study dPAL was used as described previously, MK801 impaired performance of PAL by reducing accuracy and increasing correction trials following an incorrect response. Treatment with L-govadine but not D-govadine or haloperidol blocked the disruptive effects of MK-801 in PAL. The unique ability of L-govadine to improve performance in the MK-801-induced impairment in PAL may be related to the ability of L-govadine to block dopamine $D_{2}$ receptors and also to induce dopamine efflux in the nucleus accumbens. Furthermore the impairment in PAL induced by MK-801 may be due to its effects on the dopamine system, however the lack of effect of haloperidol on MK-801 deficits in PAL suggests that D2 receptor blockade is not solely responsible for the positive effects of L-govadine in this test.

\subsection{Delayed response task-DRT}

Impairments in working memory are considered a core feature of schizophrenia (Goldman-Rakic, 1994). The delayed response task (DRT) measures spatial working memory shown to be impaired in schizophrenia (Mayer and Park, 2012). In DRTs, information is presented to a subject, and then withdrawn, for a brief delay period. The subject is then presented with a choice of two or more response alternatives and is required to choose the one previously presented to obtain reinforcement. Difficulty can be enhanced by increasing the delay interval, introducing a distracter, and/or increasing the number of choices after the delay.

McQuail and colleagues (2016) have recently studied the effects of acute, central pharmacological blockade of NR2A and NR2B NMDA receptor subtypes in the PFC of young adult rats on working memory performance using the DRT. They also assessed the degree to which attenuated expression of NMDAR subunits associates with working memory decline in aged rats and if positive modulation of PFC NMDARs in aged rats could improve working memory.

This DRT includes three phases in each trial. In the sample phase, one lever (either left or right) is extended into the chamber. Once a rat presses the lever, it is retracted and a delay phase is initiated (randomly from 0-24s) in which the rat must continuously nose poke in the centrally located food hopper. After the delay phase, the choice phase involves presentation of both levers (left and right) into the test chamber. The rat must remember the lever presented in the sample phase and choose that lever to receive a food reward. Intra-medial PFC administration of the competitive NR2Apreferring antagonist NVP-AAM077 (NVP;PEAQX or [(1S)-1-(4-bromophenyl)ethyl]amino](1,2,3,4tetrahydro-2,3-dioxo-5-quinoxalinyl)methyl] phosphonic acid tetrasodium hydrate), and the noncompetitive NR2A selective antagonist, TCN-201 (TCN;3-chloro-4-fluoro- $N$-[4-[[2(phenylcarbonyl)hydrazino]carbonyl]benzyl]benzenesulfonamide), significantly reduced the DRT choice accuracy at all doses tested compared to vehicle. Conversely, intra-medial PFC administration of two NR2B-selective antagonists, Ro 25-6981 (Ro 25; ( $\alpha$ R, $\beta S$ )- $\alpha$-(4-hydroxyphenyl)- $\beta$-methyl-4(phenylmethyl)-1-piperidinepropanol maleate) and Ifenprodil hemitartrate ((1R*,2S*)-erythro-2-(4benzylpiperidino)-1-(4-hydroxyphenyl)-1-propanol hemitartrate) failed to affect DRT performance. When DRT was assessed in the aged (22-26 months) rats, with reduced NR2A receptor expression, 
performance was impaired compared to young adult rats, particularly at longer delays. Subsequent Intra-medial PFC administration of the DAAO (D-amino acid oxidase) inhibitor MPC (3methylpyrazole-5-carboxylic acid) which prevents the breakdown of endogenous serine, significantly enhanced the performance of aged rats in DRT. These results do not support the current theories that favour contributions from NR2B- NMDARs in the PFC in working memory. Here the data suggest that mPFC NR2A, but not NR2B receptors are predominant mediators of working memory in the DRT and are relevant for cognitive status in aging.

\subsection{The trial-unique, delayed nonmatching-to-location (TUNL) task}

The trial-unique, delayed non-matching-to-location (TUNL) task is performed in rodents in touchscreen operant apparatus and, like the delayed response task, measures spatial working memory. The TUNL task like PAL, is adapted from touchscreen-based tests for humans such as the Cambridge Neuropsychological Test Automated Battery (CANTAB) spatial working memory task (Bussey et al., 2012). In TUNL, working memory is measured by delayed responding to a novel location following presentation of a sample stimulus. In this task, pattern separation, the cognitive ability to distinguish between similar patterns is assessed by varying the distance or separation between the sample and choice stimuli (Oomen et al., 2013; Davies et al., 2017).

Studies by Davies and colleagues (2017) assessed the effects of systemic injections of the competitive NMDAR antagonist CPP and an antagonist selective for the GluN2B subunit-containing receptors, RO25-6981 and bilateral intra-mPFC or dorsomedial striatum administration of the competitive NMDAR antagonist AP5 on performance of the TUNL task in operant touchscreen chambers in the rat. A standard trial of the TUNL task consists of a sample phase, during which a sample stimulus is presented in one of 14 possible locations on the screen. In the test phase two stimuli are presented, one in the sample location (incorrect) and the other in the new location (correct). A touch to the correct location results in the delivery of a food reward followed by a 20s inter-trial-interval and a touch on the incorrect location results in a $5 \mathrm{~s}$ time out followed by correction trials, repeated until correct location is selected. Systemic administration of CPP induced impairments in accuracy regardless of the degree of stimuli separation or length of delay between the sample and test while Ro 25-6981 did not affect accuracy in this task. Local Infusions of AP5 into either the dorsomedial striatum or the MPFC reduced overall accuracy in the TUNL task. These results show that the TUNL task performance can be impaired by NMDAR blockade in the PFC and the striatum.

\section{$\underline{4.5 \text { Visual signal detection (SD) task }}$}

Attention deficits are observed in patients with schizophrenia; indeed these are one of the earliest clinical manifestations of the disease and are observed in first-episode patients (Orellana et al., 2012). The operant visual signal detection (SD) task can be used to measure attentional function in rodents (Rezvani and Levin, 2003; Sarter et al., 2009). In most visual SD tasks, subjects are required to respond rapidly to a cue light presented randomly at different spatial locations, stimulus duration is either fixed or varied around a range of short intervals of one second or less. To perform this task accurately, rodents are required to initiate a response within a short period after the light. An intertrial interval separates stimulus presentations (Echevarria et al., 2005). 
Rezvani and Colleagues (2012) assessed the effects of AZD3480, an $\alpha 4 \beta 2$ nicotinic receptor agonist in comparison to the cholinesterase inhibitor, donepezil on attention and reversal of pharmacologically induced attentional impairment produced by MK-801 in adult rats in an operant visual SD task. Animals were trained and rewarded with a $20 \mathrm{mg}$ sugar pellet to press the signal lever on a signal trial (Hit) and the blank lever on the blank trial (correct rejections). Acute MK-801 induced a significant impairment in percent correct performance, significantly reversed by acute treatment with AZD3480 and donepezil with similar efficacy. This study supports a role for $\alpha 4 \beta 2$ nicotinic receptors in attention in schizophrenia.

In summary, a wide variety of NMDAR antagonists, given in both acute and sub-chronic dosing regimens, via systemic and central application consistently (apart from Fellini's SCPCP reversal learning study, see table 2) produce robust deficits in operant tasks of cognitive function relating to domains affected in schizophrenia in female and male Lister Hooded rats, in male rats of Fischer and Long Evans strains and also in male C57BL/6J mice. This is demonstrated by the studies published since our initial review in 2010 and confirms that operant studies are a reliable way to investigate mechanisms of learning and memory of relevance to schizophrenia. Furthermore, a variety of novel agents in addition to comparator compounds demonstrated efficacy to reverse/prevent these NMDAR-induced cognitive deficits. New touchscreen technology appears to have assisted in advancing the range of cognitive tests that can be examined using operant technology.

\section{TABLE 2 HERE}

\section{Neuropathology - Parvalbumin GABAergic interneurons}

GABAergic interneurons regulate a number of cognitive functions and are dysregulated across a range of psychiatric disorders. In particular, abnormalities of the GABAergic system in schizophrenia are reliably demonstrated (see Lewis, 2014 for recent review). As outlined in our 2010 review, there is much evidence for a link between abnormal GABA and glutamate neurotransmission through NMDAR receptor hypofunction and the appearance of pathological features in animals of relevance to schizophrenia. A particular focus for this current review is the relationship between prolonged blockade of NMDARs in adult rodents and alterations of local GABAergic interneurons, specifically PV-positive fast-spiking interneurons, in brain regions relevant for cognition in schizophrenia, hippocampus and PFC. We focus here on work published since our 2010 review. These PV interneurons are critical for the generation and synchronization of gamma-band oscillations (Sohal et al., 2009) which in turn control cognitive processes. As outlined in this review, these processes are impaired in schizophrenia and associated rodent models.

Redrobe and colleagues demonstrated SCPCP-induced PV deficits in the PFC and cognitive deficits in both NOR and ASST in male Lister Hooded rats, $5 \mathrm{mg} / \mathrm{kg}$ i.p. twice daily for 5 days followed by washout (Redrobe et al., 2012). Amitai and colleagues (2012) reported reduced levels of PV and glutamic acid decarboxylase-67-GAD67 (two markers of GABA function) in the PFC following SCPCP administration ( $2 \mathrm{mg} / \mathrm{kg}$ once daily over 5 days-non-consecutively- in male Wistar rats, see Amitai et al. 2012, for full details of experimental design). This effect was present after a 10 day drug-free washout period, was unaltered by the resumption of repeated PCP injections and was reversed by chronic treatment with clozapine (4 mg/kg/day). In our laboratory we have demonstrated efficacy of chronic treatment (21 days) with a novel Kv3.1/3.2 channel modulator, AUT00206, to improve both 
the behavioural and pathological deficits (PV reductions in the PFC and hippocampus) in our sCPCP model, $2 \mathrm{mg} / \mathrm{kg}$ i.p. twice daily followed by 6 weeks drug free in female Lister Hooded rats (Leger et al., 2015). More recently we have also reported a specific hypermethylation in the Pvalb promoter which may contribute to PV deficits in this model (Fachim et al., 2016).

As outlined in our 2010 review, other NMDAR antagonists produce similar effects on pathology. Using a sub-chronic ketamine mouse model (30 mg/kg i.p. once daily for 14 days in male C57BI6/N mice) impairments in novelty discrimination in conjunction with reduced PV expression in PFC and dorsal hippocampus were observed (Hauser et al., 2017). Chronic ketamine in adult rats $(8 \mathrm{mg} / \mathrm{kg}$ s.c. once daily in male Sprague-Dawley rats over 18 days) has been shown to alter the distribution of PV-positive cells in the hippocampus, accompanied by behavioural deficits (Sabbagh et al., 2013). Benneyworth and colleagues (2011) investigated PV expression in mice (male SR homozygous null mutant and wildtype) and rats (male Sprague-Dawley) following SCPCP $(6 \mathrm{mg} / \mathrm{kg}$ s.c. once daily for 5 days) or ketamine (30 mg/kg s.c.-mice and i.p.-rats once daily for 5 days) treatment in adulthood. In this study, NMDAR antagonism failed to produce induce reductions in PV-positive GABAergic cell markers in the PFC or hippocampus. In these studies all investigations were carried out 72 hours after the last drug treatment. In our hands the PV deficits are most robust 6 weeks post SCPCP (see our original work on this, Abdul-Monim et al. 2007, commentary by Reynolds and Neill, 2016 and most recent results in Leger et al. 2015) intriguingly behavioural deficits are observed 7 days post scPCP (and persist for up to 8 months, Grayson personal communication). Therefore, in the Benneyworth study, it may have been too early post scketamine for PV deficits to be detected, and they did not confirm their deficits with behaviour. However this does not appear to be the case for ketamine in the Hauser study (2017), where PV deficits were observed post-behaviour and 72 hours post-ketamine, albeit in mice not rats.

More recently, evidence for the clinical use of ketamine as a rapid antidepressant has emerged. However concerns about its side effects following long term use are warranted (Short et al., 2017). Interestingly Yang et al (2016) reported a loss of PV-immunoreactivity in mouse brain regions after repeated intermittent administration of esketamine $(10 \mathrm{mg} / \mathrm{kg}$ once a week for 8 weeks) but not following R-ketamine, suggesting that repeated intermittent use of R-ketamine may be safer than esketamine in the treatment of depression.

Alongside the use of sub-chronic administration of NMDAR antagonists in adulthood, there are numerous studies investigating the effects of neonatal blockade of NMDA receptors (using PCP, ketamine and MK-801). These neurodevelopmental insults have been associated with schizophrenia related cognitive and pathological deficits in adulthood. Again, evidence for a robust effect on the development of PV interneurons emerges (e.g. Jeevakumar et al., 2015; Turner et al., 2010; Wang et al., 2008). We reviewed the pathology and behaviour induced by post-natal NMDAR antagonism in 2015 (Grayson et al., 2015) please refer to this publication for details of these studies.

Enhanced understanding of the functional role of these fast spiking PV interneurons in the generation of neural oscillations and their potential role in the control of cognitive function is emerging from both clinical and preclinical studies. The effects of acute and sub-chronic administration of NMDAR antagonists on these oscillations in rodents are summarised in the section below. 


\section{Gamma oscillations, a mediator of cognitive control}

Neural oscillations are a fundamental process for effective communication within neural assemblies (Fell and Axmacher, 2011, Uhlhaas and Singer, 2013). There is a strong correlation between oscillations in certain frequency bands and cognition. For example, changes in the hippocampal and cortical theta frequency band $(\sim 3-8 \mathrm{~Hz})$ have consistently been reported during working memory (Meltzer et al., 2008, Lisman and Jensen, 2013) and encoding of episodic memory in awake rats, primates and humans measured using electroencephalography (EEG) and similar techniques (Lega et al, 2012; Shirvalkar et al., 2010; please see Wang, 2010 for a comprehensive review). In recent years, a critical role for gamma oscillations $(\sim 30-80 \mathrm{~Hz})$ in higher-order cognitive and perceptual processes has been identified (Gonzalez-Burgos et al., 2015). An increase in cortical and hippocampal gamma power has been implicated in cognitive processes including, but not limited to, working memory (Lisman and Jensen, 2013) and executive function (Cho et al., 2006, Lesh et al., 2011). Furthermore cross-frequency phase and amplitude locking mechanisms across brain-wide regions allow for precise information coding and accompany complex cognitive processes (Fell and Axmacher, 2011). For instance, theta-gamma coupling within the local hippocampal network (Heusser et al., 2016) and between the hippocampus and PFC is involved in processing episodic memory (Nyhus and Curran, 2010) and in goal-directed behaviour (Numan, 2015). It is therefore suggested that synchronous and coherent oscillatory activity within local-networks and between functionally related brain regions could represent the neural correlates of cognition (Uhlhaas and Singer 2013).

Schizophrenia is associated with changes in synchrony and power across various frequency bands (Koh et al., 2011, Hoptman et al., 2010, Wang, 2010). Of particular importance to understanding the nature of CIAS is the alteration in the power of gamma oscillations and disturbances of gamma coupling to other frequencies in the hippocampus and cortex. Several studies have reported reduced frequency and power in local gamma oscillations in patients performing a variety of perceptual and cognitive tasks (Minzenberg et al., 2010; Chen et al., 2014; Ferrarelli et al., 2008; Spencer et al., 2004). This is while gamma oscillation power seems to increase during resting-state in patients with schizophrenia (Andreou et al., 2015). In addition to abnormalities in gamma power, local synchrony and stimulus locking to gamma oscillation phase is disrupted in schizophrenia (Uhlhaas and Singer., 2010, Cho et al., 2006, Spencer et al., 2004, Spencer et al., 2003). Emerging evidence also points towards reduced long-range gamma synchronisation in patients with schizophrenia (Mulert et al., 2011, Uhlhaas et al., 2006). These disturbances in gamma oscillations link the pathophysiology and disturbances in local networks to the cognitive and perceptual disturbances associated with the disease (Pittman-Polletta et al., 2015).

GABA - mediated neuronal inhibition is a key element in the generation of gamma oscillations (Chen et al., 2014, Gonzalez-Burgos et al., 2015). Because of their fast-spiking dynamics, PV-containing GABAergic basket cells (PVBC) are strongly linked to generating oscillations in the gamma frequency range. This has been confirmed by a range of in vivo (Massi et al., 2012, Carlen et al., 2012, Sohal et al., 2009) and in vitro (Rotaru et al., 2011, Gulyas et al., 2010) studies. These cells predominately target the perisomatic region of pyramidal neurons and synchronise the activity of pyramidal neurons within the gamma range with great temporal precision (Gonzalez-Burgos and Lewis, 2012). Based on the Pyramidal-Interneuron Network Gamma (PING) circuit model, gamma oscillations are 
generated through recurrent synapses between pyramidal neurons and PVBC creating a balanced excitatory-inhibitory circuit. Accordingly, the interneurons are recruited in a phasic manner through an $\alpha$-amino-3-hydroxy-5-methyl-4-isoxazolepropionic acid receptor (AMPAR)-mediated excitatory input from the pyramidal neurons (Gonzalez-Burgos and Lewis, 2012, Gonzalez-Burgos et al., 2015) which fire first in the gamma cycle (Hajos and Paulsen, 2009, Korotkova et al., 2010).

NMDARs located on the interneurons have been implicated in modulating oscillations in the gamma frequency range (Cohen et al., 2015, Jadi et al., 2016) disturbances of which are observed in both pharmacological and genetic models (Carlen et al., 2012) of NMDAR hypofunction in schizophrenia (Jadi et al., 2016). Acute administration of ketamine (10-50 $\mu \mathrm{M})$ in slice preparations from adult male Wistar rats produces a reduction in the power of gamma oscillations in the entorhinal cortex (Cunningham et al., 2006) while similar treatment (Ketamine 10-20 $\mu \mathrm{M}$ ) enhanced gamma power in the auditory cortex of the same sex and strain of rats (Roopun et al., 2008). In vivo, acute systemic administration of ketamine (at 9 and $30 \mathrm{mg} / \mathrm{kg}$ ) in freely moving adult male Wistar rats increased gamma power in several cortical regions. This effect, obtained from freely moving animals using EEG, was independent of the effect of ketamine on locomotor activity (Palenicek et al., 2011). In another study, acute treatment with ketamine $(10 \mathrm{mg} / \mathrm{kg})$ and $\mathrm{MK}-801(0.2 \mathrm{mg} / \mathrm{kg})$ in awake male adult Sprague-Dawley rats increased gamma power in both the CA1 and dentate gyrus of the hippocampus (Kittelberger et al., 2012). Similarly, acute treatment with MK-801 $(0.1-0.2 \mathrm{mg} / \mathrm{kg}$ ) was found to significantly reduce gamma synchrony and increase the amplitude of gamma oscillations in the prelimbic region of the PFC in freely moving Brown-Norway or Brown-Norway Fischer hybrid rats (Molina et al., 2014). As shown by Hakami and colleagues (2009), this elevated gamma power in cortical and sub-cortical structures in the presence of acute ketamine $(5 \mathrm{mg} / \mathrm{kg})$ or MK-801 $(0.08 \mathrm{mg} / \mathrm{kg})$ in adult male Wistar rats is independent of various states of consciousness in the tested animals.

In comparison to pyramidal neurons, cortical interneurons are more sensitive to the effects of NMDAR antagonists (Homayoun and Moghaddam, 2007). In the presence of an NMDAR antagonist the firing rate of the interneurons is reduced. This results in disinhibition of the pyramidal neurons manifest as an increase in their firing rate (cortical disinhibition phenomenon). Reduced GABAmediated inhibition on pyramidal neurons may result in disorganised firing of these neurons rendering information processing less precise and finely tuned (Molina et al., 2014) and may contribute to the cortical disinhibition associated with cognitive deficits in patients. The observed increase in the power of gamma oscillations is not immediately explained by the phenomenon of cortical disinhibition however. Emerging evidence suggests that the inhibitory role of non-PV containing interneurons (such as somatostatin positive interneurons) in regulating gamma oscillations may explain elevated power in the presence of acute NMDAR blockade (Jadi et al., 2016, Molina et al., 2014, Xu et al., 2013).

Currently, there is a clear gap in the literature regarding the influence of chronic or sub-chronic treatment with NMDAR antagonists on CNS oscillations in general. Of the few studies in this area, results show that sub-chronic administration of the NMDAR antagonist (ketamine $30 \mathrm{mg} / \mathrm{kg}$ i.p. for 5 days) was associated with reduced gamma power in hippocampal regions (CA1 and dentate gyrus) of awake adult male Sprague-Dawley rats over 2-4 weeks post ketamine treatment (Kittelberger et al., 2012). Another study reported abnormal synchronisation in the pyramidal neurons of the PFC in anaesthetised male Wistar rats following scPCP treatment $(2 \mathrm{mg} / \mathrm{kg}$ twice daily followed by 7 days 
drug free) (Young et al., 2015). Recent evidence also points towards the detrimental effect of scPCP ( $2 \mathrm{mg} / \mathrm{kg}$ twice daily followed by 7 days drug free) on cross-regional communication and synchronisation mechanisms during performance of the NOR task in adult female Lister Hooded rats (Asif-Malik et al., 2017).

Emerging evidence from our laboratory also points towards disrupted coherence in the mPFCventral hippocampus network (unpublished data) and instability of long-term potentiation (Doostdar et al., 2017) in mPFC neurons following ventral hippocampus stimulation in adult female Lister Hooded rats sub-chronically treated with PCP ( $2 \mathrm{mg} / \mathrm{kg}$ i.p. twice daily followed by 7 days drug free). These studies suggest a profound molecular and network alteration in our SCPCP model that induces robust cognitive and social behavioural deficits as described in this article and elsewhere (Neill et al., 2014, Neill et al., 2010).

Indeed abnormalities in GABAergic signalling and expression of PV are well documented in patients with schizophrenia (see Lewis, 2014 for recent review). It is thought that such GABAergic disturbances are mediated by reduced activity of NMDARs located on fast-spiking PV-containing interneurons. This is supported by studies showing a reduction in the expression of PV following systemic administration of NMDAR antagonists in rodents (Behrens et al., 2007, Cochran et al., 2003, Kittelberger et al., 2012, see section 5 this review). Indeed, we consistently find a reduction in the expression of PV in our ScPCP model (Abdul-Monim et al. 2007; Reynolds and Neill, 2016). This key pathological element, in addition to an array of well characterised cognitive and social impairments associated with the sub-chronic NMDAR antagonist model make it a very valuable tool for drug discovery. Characterising this model in terms of its electrophysiological properties is warranted as this will enable better understanding of the mechanistic underpinnings of CIAS. Restoration of the electrophysiological signature by novel drug targets in combination with cognitive assessment will enable detailed understanding of their mechanism of action, target engagement and enable appropriate dose and drug selection for progression into clinical studies. Unfortunately such studies have not been routinely conducted prior to clinical evaluation which may explain, at least in part, the failure in clinical trials in this area so far (Bespalov et al. 2016).

\section{Discussion and conclusions}

In summary, the NMDAR antagonist model has proved to be a useful tool in the development of new drugs for schizophrenia such as lurasidone, cariprazine and asenapine. It remains to be determined whether these drugs will improve CIAS, they clearly demonstrate antipsychotic efficacy and have a $\mathrm{D}_{2}$ receptor mechanism at their core. The additional pharmacology of lurasidone (namely $5-\mathrm{HT}_{7}$ receptor antagonism and partial agonist activity at the $5-\mathrm{HT}_{1 \mathrm{~A}}$ receptor) and initial clinical findings suggest that it may have benefits for this unmet clinical need. The same applies to cariprazine which has a unique pharmacology in that it is a partial agonist at both $D_{2}$ and $D_{3}$ receptors with preferential binding at $D_{3}$ receptors, initial studies suggest that it may have efficacy for CIAS, but further trails are required to confirm this. No drug has yet received a license for CIAS or negative symptoms, however, certain pharmacological agents with a novel mechanism of action look promising such as the Autifony KV3.1/3.2 molecule, AUT00206, which shows efficacy to restore SCPCP-induced deficits in animals in a variety of test situations in addition to CNS PV deficits, see table 3 . However, table 3 reveals, rather worryingly, that few targets have been tested in more than one test situation or in more than one NMDAR antagonist model, and when this has been done, it is usually by the same 
laboratory. Even fewer have been evaluated for effects on a biomarker of relevance to CIAS, only AUT00206 and R04938581, the $\alpha 5$ GABAA receptor negative modulator, table 3.

The critical issue of preclinical versus clinical efficacy remains to be systematically evaluated and thereby the usefulness of the animal models. We have discussed this issue in several previous publications (Neill et al. 2010, 2014, and, most recently for the $\alpha 7$ receptor partial agonist, encenicline, in Hayward et al, 2017). This is clearly a complex issue, but most of the targets showing efficacy in NMDAR antagonist models described above, have at least reached Phase II clinical trials, most failed at this stage and were not progressed but of course some molecules such as Roche's bitopertin, Eli Lilly's MGluR2/3 receptor agonist and encenicline failed at the very costly Phase III stage. A particularly interesting analysis has been performed by Bespalov and colleagues (2016), notably several of the authors are scientists working in the pharmaceutical industry. In their paper, they outline the reasons for failed clinical trials following successful preclinical evaluation. They conclude that it is not the fault of the animal models per se, although these do require improved and more robust experimental design, a conclusion we concur with. It is of course essential to work with robust and reproducible translational animal models, and the ScNMDAR antagonist model does appear to fulfil these criteria. It is very reliable, evidence for this is that it has been established by many research groups, both in academia and in the pharmaceutical industry, as discussed by us previously (see Reynolds and Neill. 2016). An important explanation provided by Bespalov and colleagues is lack of target engagement work to identify the correct dose and drug candidate to be taken forward into clinical trials. They conducted an in-depth analysis of 72 novel drugs (many of the same targets are described here) and revealed that in $80 \%$ of the studies they could not find any evidence for dose selection based on target engagement or through biomarker evaluation (using eg $\mathrm{PET}, \mathrm{MRI}$ or EEG). The authors conclude that their findings challenge the incorrect assumption that these targets are invalid or that the animal models are flawed. Incorporating careful dose selection work prior to phase II trials would seem to be an obvious way to conduct clinical studies in this area, therefore it is particularly surprising to find that this is not routinely done. This approach, along with the type of patient stratification work described by Carol Tamminga and colleagues (Clementz et al. 2016) could radically improve clinical trial outcome in this area.

In terms of the future of animal work, in order to improve translational value, several issues must be resolved. These include, development of improved ethologically relevant tasks assessing different aspects of cognition and negative symptoms; inclusion of both sexes with increased inclusion of females in research; publication of negative results (see Munafo and Neill, 2016); incorporation of clinically relevant doses and dosing regimens of antipsychotics where the drug is to be added onto existing therapy; addition of mechanistic studies; target engagement and biomarker work, and the use of more than one animal model representing different biotypes and aetiologies. In addition, a real commitment to animal welfare is essential for any animal research to be valid. This holistic approach is time-consuming and expensive but considerably cheaper than financing negative results in large scale clinical trials. If these principles are adhered to in preclinical studies and appropriate target engagement and biomarker studies are conducted prior to Phase II clinical trials, we predict enhanced success in this area. As an example of good practice, the Autifony molecule has been thoroughly evaluated in preclinical studies, in more than one animal model, and is currently undergoing the target engagement and biomarker studies recommended by Bespalov and colleagues. It remains to be determined whether this will lead to success in the clinic. However, if 
not, this will not be due to insufficient evaluation in preclinical or clinical studies and could provide a gold standard for hypothesis driven drug discovery in psychiatry in the future.

TABLE 3 HERE

Funding Source

Studies of their own cited by the authors were funded indirectly by b-neuro at the University of Manchester (UoM). ND is funded by a University of Manchester President's doctoral scholarship. DC was funded by a grant awarded to the University of Manchester from Autifony Therapeutics Ltd with Innovate UK (formerly TSB). All authors are (or were at the time of writing, DC) full-time employees of the University of Manchester. GP is a part-time PhD student who also conducts studies for bneuro at UoM. Some authors (DC, GP and ND) are fixed term contract researchers/technicians/students who are paid from research income generated from a range of external funding sources, notably from various Pharmaceutical companies, but also from research councils, research charities and the University of Manchester.

\section{Declaration of interest}

$\mathrm{JCN}$ has received expenses to attend conferences and fees for lecturing and consultancy work (including attending advisory boards) from the manufacturers of various antipsychotic drugs.

\section{References}

Abdul-Monim, Z., Neill, J. C., Reynolds, G. P., 2007. Sub-chronic psychotomimetic phencyclidine induces deficits in reversal learning and alterations in parvalbumin-immunoreactive expression in the rat. J Psychopharmacol 21, 198-205.

Akbarian, S., Bunney, W. E., Potkin, S. G., Wigal, S. B., Hagman, J. O., Sandman, C. A., Jones, E. G., 1993. Altered Distribution of Nicotinamide-Adenine Dinucleotide Phosphate Diaphorase Cells in Frontal-Lobe of Schizophrenics Implies Disturbances of Cortical Development. Arch Gen Psychiatry 50, 169-177.

Amitai, N., Kuczenski, R., Behrens, M. M., Markou, A., 2012. Repeated phencyclidine administration alters glutamate release and decreases GABA markers in the prefrontal cortex of rats. Neuropharmacology 62, 1422-1431.

Andreou, C., Nolte, G., Leicht, G., Polomac, N., Hanganu-Opatz, I. L., Lambert, M., Engel, A. K., Mulert, C., 2015. Increased Resting-State Gamma-Band Connectivity in First-Episode Schizophrenia. Schizophr Bull 41, 930-939.

Asif-Malik, A., Dautan, D., Young, A. M., Gerdjikov, T. V., 2017. Altered cortico-striatal crosstalk underlies object recognition memory deficits in the sub-chronic phencyclidine model of schizophrenia. Brain Struct Funct.

Barnett, J. H., Robbins, T. W., Leeson, V. C., Sahakian, B. J., Joyce, E. M., Blackwell, A. D., 2010. Assessing cognitive function in clinical trials of schizophrenia. Neurosci Biobehav Rev 34, 1161-1177.

Barnett, J. H., Sahakian, B. J., Werners, U., Hill, K. E., Brazil, R., Gallagher, O., Bullmore, E. T., Jones, P. B., 2005. Visuospatial learning and executive function are independently impaired in first-episode psychosis. Psychol Med 35, 1031-1041. 
Behrens, M. M., Ali, S. S., Dao, D. N., Lucero, J., Shekhtman, G., Quick, K. L., Dugan, L. L., 2007. Ketamine-induced loss of phenotype of fast-spiking interneurons is mediated by NADPH-oxidase. Science 318, 1645-1647.

Benneyworth, M. A., Roseman, A. S., Basu, A. C., Coyle, J. T., 2011. Failure of NMDA receptor hypofunction to induce a pathological reduction in PV-positive GABAergic cell markers. Neuroscience Letters 488, 267-271.

Berg, E. A., 1948. A Simple Objective Technique for Measuring Flexibility in Thinking. Journal of General Psychology 39, 15-22.

Bernaerts, P., Tirelli, E., 2003. Facilitatory effect of the dopamine D4 receptor agonist PD168,077 on memory consolidation of an inhibitory avoidance learned response in C57BL/6J mice. Behav Brain Res 142, 41-52.

Bespalov, A., Steckler, T., Altevogt, B., Koustova, E., Skolnick, P., Deaver, D., Millan, M. J., Bastlund, J. F., Doller, D., Witkin, J., Moser, P., O'Donnell, P., Ebert, U., Geyer, M. A., Prinssen, E., Ballard, T., Macleod, M., 2016. Failed trials for central nervous system disorders do not necessarily invalidate preclinical models and drug targets. Nat. Rev. Drug Discov. 15, 516-516.

Birrell, J. M., Brown, V. J., 2000. Medial frontal cortex mediates perceptual attentional set shifting in the rat. Journal of Neuroscience 20, 4320-4324.

Branch, S. Y., Goertz, R. B., Sharpe, A. L., Pierce, J., Roy, S., Ko, D., Paladini, C. A., Beckstead, M. J., 2013. Food restriction increases glutamate receptor-mediated burst firing of dopamine neurons. J Neurosci 33, 13861-13872.

Browman, K. E., Curzon, P., Pan, J. B., Molesky, A. L., Komater, V. A., Decker, M. W., Brioni, J. D., Moreland, R. B., Fox, G. B., 2005. A-412997, a selective dopamine D4 agonist, improves cognitive performance in rats. Pharmacol Biochem Behav 82, 148-155.

Bussey, T. J., Holmes, A., Lyon, L., Mar, A. C., McAllister, K. A., Nithianantharajah, J., Oomen, C. A., Saksida, L. M., 2012. New translational assays for preclinical modelling of cognition in schizophrenia: the touchscreen testing method for mice and rats. Neuropharmacology 62, 1191-1203.

Cadinu, D., Podda, G., Doostdar, N.,Harte, M. K., Neill, J.C., Alvaro, G., Large, C., 2016. AUT00206, a novel and selective KV3 channel modulator restores cognitive function in the sub-chronic phencyclidine rat model for schizophrenia in the presence of chronic treatment with antipsychotic drugs. J. Psychopharmacol. Suppl. 30(8): A30.

Carlen, M., Meletis, K., Siegle, J. H., Cardin, J. A., Futai, K., Vierling-Claassen, D., Ruhlmann, C., Jones, S. R., Deisseroth, K., Sheng, M., Moore, C. I., Tsai, L. H., 2012. A critical role for NMDA receptors in parvalbumin interneurons for gamma rhythm induction and behavior. Mol Psychiatry 17, 537-548.

Chen, C. M., Stanford, A. D., Mao, X., Abi-Dargham, A., Shungu, D. C., Lisanby, S. H., Schroeder, C. E., Kegeles, L. S., 2014. GABA level, gamma oscillation, and working memory performance in schizophrenia. Neuroimage Clin 4, 531-539.

Cho, R. Y., Konecky, R. O., Carter, C. S., 2006. Impairments in frontal cortical gamma synchrony and cognitive control in schizophrenia. Proc Natl Acad Sci U S A 103, 19878-19883.

Clayton, J.A., Collins, F.S., 2014. Policy: NIH to balance sex in cell and animal studies. Nature 509, 282-283. 
Clementz, B. A., Sweeney, J. A., Hamm, J. P., Ivleva, E. I., Ethridge, L. E., Pearlson, G. D., Keshavan, M. S., Tamminga, C. A., 2016. Identification of Distinct Psychosis Biotypes Using Brain-Based Biomarkers. American Journal of Psychiatry 173, 373-384.

Cochran, S. M., Kennedy, M., McKerchar, C. E., Steward, L. J., Pratt, J. A., Morris, B. J., 2003. Induction of metabolic hypofunction and neurochemical deficits after chronic intermittent exposure to phencyclidine: differential modulation by antipsychotic drugs. Neuropsychopharmacology 28, 265-275.

Cohen, S. M., Tsien, R. W., Goff, D. C., Halassa, M. M., 2015. The impact of NMDA receptor hypofunction on GABAergic neurons in the pathophysiology of schizophrenia. Schizophr Res 167, 98107.

Corrigan, M. H., Gallen, C. C., Bonura, M. L., Merchant, K. M., Sonepiprazole Study, G., 2004. Effectiveness of the selective D4 antagonist sonepiprazole in schizophrenia: a placebo-controlled trial. Biol Psychiatry 55, 445-451.

Cunningham, M. O., Hunt, J., Middleton, S., LeBeau, F. E., Gillies, M. J., Davies, C. H., Maycox, P. R., Whittington, M. A., Racca, C., 2006. Region-specific reduction in entorhinal gamma oscillations and parvalbumin-immunoreactive neurons in animal models of psychiatric illness. J Neurosci 26, 27672776.

Damgaard, T., Plath, N., Neill, J. C., Hansen, S. L., 2011. Extrasynaptic GABA(A) receptor activation reverses recognition memory deficits in an animal model of schizophrenia. Psychopharmacology (Berl) 214, 403-413.

Darrah, J. M., Stefani, M. R., Moghaddam, B., 2008. Interaction of N-methyl-D-aspartate and group 5 metabotropic glutamate receptors on behavioral flexibility using a novel operant set-shift paradigm. Behav Pharmacol 19, 225-234.

Davies, D. A., Hurtubise, J. L., Greba, Q., Howland, J. G., 2017. Medial prefrontal cortex and dorsomedial striatum are necessary for the trial-unique, delayed nonmatching-to-location (TUNL) task in rats: role of NMDA receptors. Learn Mem 24, 262-266.

de Almeida, J., Mengod, G., 2010. D2 and D4 dopamine receptor mRNA distribution in pyramidal neurons and GABAergic subpopulation in monkey prefrontal cortex: implications for schizophrenia treatment. Neuroscience 170, 1133-1139.

Dere, E., Huston, J. P., De Souza Silva, M. A., 2007. The pharmacology, neuroanatomy and neurogenetics of one-trial object recognition in rodents. Neurosci Biobehav Rev 31, 673-704.

Doostdar,N., Davy, N. O., Neill, J. C., Gigg, J., 2017. Electrophysiological properties of the hippocampus-medial prefrontal cortex pathway in the sub-chronic phencyclidine model for schizophrenia, J. Psychopharmacol supplement to issue 31(8), A118

Downes, J. J., Roberts, A. C., Sahakian, B. J., Evenden, J. L., Morris, R. G., Robbins, T. W., 1989. Impaired extra-dimensional shift performance in medicated and unmedicated Parkinson's disease: evidence for a specific attentional dysfunction. Neuropsychologia 27, 1329-1343.

Echevarria, D. J., Brewer, A., Burk, J. A., Brown, S. N., Manuzon, H., Robinson, J. K., 2005. Construct validity of an operant signal detection task for rats. Behav Brain Res 157, 283-290.

Ennaceur, A., 2010. One-trial object recognition in rats and mice: Methodological and theoretical issues. Behav Brain Res 215, 244-254. 
Ennaceur, A., Delacour, J., 1988. A New One-Trial Test for Neurobiological Studies of Memory in Rats 1. Behavioral-Data. Behav Brain Res 31, 47-59.

Eskildsen, J., Redrobe, J. P., Sams, A. G., Dekermendjian, K., Laursen, M., Boll, J. B., Papke, R. L., Bundgaard, C., Frederiksen, K., Bastlund, J. F., 2014. Discovery and optimization of Lu AF58801, a novel, selective and brain penetrant positive allosteric modulator of alpha-7 nicotinic acetylcholine receptors: Attenuation of subchronic phencyclidine (PCP)-induced cognitive deficits in rats following oral administration. Bioorganic \& Medicinal Chemistry Letters 24, 288-293.

Fachim, H. A., Srisawat, U., Dalton, C. F., Harte, M. K., Marsh, S., Neill, J. C., Reynolds, G. P., 2016. Subchronic administration of phencyclidine produces hypermethylation in the parvalbumin gene promoter in rat brain. Epigenomics 8, 1179-1183.

Fell, J., Axmacher, N., 2011. The role of phase synchronization in memory processes. Nat Rev Neurosci 12, 105-118.

Fellini, L., Kumar, G., Gibbs, S., Steckler, T., Talpos, J., 2014. Re-evaluating the PCP challenge as a preclinical model of impaired cognitive flexibility in schizophrenia. Eur Neuropsychopharmacol 24, 18361849.

Ferrarelli, F., Massimini, M., Peterson, M. J., Riedner, B. A., Lazar, M., Murphy, M. J., Huber, R., Rosanova, M., Alexander, A. L., Kalin, N., Tononi, G., 2008. Reduced evoked gamma oscillations in the frontal cortex in schizophrenia patients: A TMS/EEG study. American Journal of Psychiatry 165, 996-1005.

Garnock-Jones, K. P., 2017. Cariprazine: A Review in Schizophrenia. CNS Drugs 31, 513-525.

Gastambide, F., Mitchell, S. N., Robbins, T. W., Tricklebank, M. D., Gilmour, G., 2013. Temporally distinct cognitive effects following acute administration of ketamine and phencyclidine in the rat. European Neuropsychopharmacology 23, 1414-1422.

Georgiadou, G., Grivas, V., Tarantilis, P. A., Pitsikas, N., 2014. Crocins, the active constituents of Crocus Sativus L., counteracted ketamine-induced behavioural deficits in rats. Psychopharmacology (Berl) 231, 717-726.

Ghiron, C., Haydar, S. N., Aschmies, S., Bothmann, H., Castaldo, C., Cocconcelli, G., Comery, T. A., Di, L., Dunlop, J., Lock, T., Kramer, A., Kowal, D., Jow, F., Grauer, S., Harrison, B., La Rosa, S., Maccari, L., Marquis, K. L., Micco, I., Nencini, A., Quinn, J., Robichaud, A. J., Roncarati, R., Scali, C., Terstappen, G. C., Turlizzi, E., Valacchi, M., Varrone, M., Zanaletti, R., Zanelli, U., 2010. Novel Alpha-7 Nicotinic Acetylcholine Receptor Agonists Containing a Urea Moiety: Identification and Characterization of the Potent, Selective, and Orally Efficacious Agonist 1[6-(4-Fluorophenyl)pyridin-3-yl]-3-(4-piperidin-1ylbutyl) Urea (SEN34625/WYE-103914). Journal of Medicinal Chemistry 53, 4379-4389.

Gill, K. M., Grace, A. A., 2014. The role of alpha5 GABAA receptor agonists in the treatment of cognitive deficits in schizophrenia. Curr Pharm Des 20, 5069-5076.

Glase, S. A., Akunne, H. C., Georgic, L. M., Heffner, T. G., MacKenzie, R. G., Manley, P. J., Pugsley, T. A., Wise, L. D., 1997. Substituted [(4-phenylpiperazinyl)-methyl]benzamides: selective dopamine D4 agonists. Journal of Medicinal Chemistry 40, 1771-1772.

Goetghebeur, P. J. D., Dias, R., 2014. The Attentional Set-Shifting Test Paradigm in Rats for the Screening of Novel Pro-Cognitive Compounds with Relevance for Cognitive Deficits in Schizophrenia. Current Pharmaceutical Design 20, 5060-5068. 
Goldmanrakic, P. S., 1994. Working-Memory Dysfunction in Schizophrenia. Journal of Neuropsychiatry and Clinical Neurosciences 6, 348-357.

Gonzalez-Burgos, G., Cho, R. Y., Lewis, D. A., 2015. Alterations in Cortical Network Oscillations and Parvalbumin Neurons in Schizophrenia. Biol Psychiatry 77, 1031-1040.

Gonzalez-Burgos, G., Lewis, D. A., 2012. NMDA Receptor Hypofunction, Parvalbumin-Positive Neurons, and Cortical Gamma Oscillations in Schizophrenia. Schizophr Bull 38, 950-957.

Grayson, B., Barnes, S.A., Markou, A., Piercy, C., Podda, G., Neill, J.C., 2016. Postnatal phencyclidine (PCP) as a neurodevelopmental animal model of schizophrenia pathophysiology and symptomatology: A review. Curr. Top. Behav. Neurosci. 29, 403-428.

Grayson B., Fasolino V., Edye M., Oladipo J., Idris N.F., Harte M.K., Neill J.C. 2017. Cognitive and social behaviour deficits at adulthood in female rat offspring of Poly I:C treated rat dams, a developmental model for schizophrenia. J. Psychopharmacology suppl. 31(8), E40.

Grayson, B., Idris, N. F., Neill, J. C., 2007. Atypical antipsychotics attenuate a sub-chronic PCPinduced cognitive deficit in the novel object recognition task in the rat. Behav Brain Res 184, 31-38.

Grayson, B., Leger, M., Piercy, C., Adamson, L., Harte, M., Neill, J. C., 2015. Assessment of diseaserelated cognitive impairments using the novel object recognition (NOR) task in rodents. Behav Brain Res 285, 176-193.

Gulyas, A. I., Szabo, G. G., Ulbert, I., Holderith, N., Monyer, H., Erdelyi, F., Szabo, G., Freund, T. F., Hajos, N., 2010. Parvalbumin-containing fast-spiking basket cells generate the field potential oscillations induced by cholinergic receptor activation in the hippocampus. J Neurosci 30, 1513415145.

Hajos, N., Paulsen, O., 2009. Network mechanisms of gamma oscillations in the CA3 region of the hippocampus. Neural Netw 22, 1113-1119.

Hakami, T., Jones, N. C., Tolmacheva, E. A., Gaudias, J., Chaumont, J., Salzberg, M., O'Brien, T. J., Pinault, D., 2009. NMDA receptor hypofunction leads to generalized and persistent aberrant gamma oscillations independent of hyperlocomotion and the state of consciousness. Plos One 4, e6755.

Harvey, P. D., 2015. The clinical utility of lurasidone in schizophrenia: patient considerations. Neuropsychiatr Dis Treat 11, 1103-1109.

Hashimoto, K., Ishima, T., Fujita, Y., Matsuo, M., Kobashi, T., Takahagi, M., Tsukada, H., Iyo, M., 2008. Phencyclidine-induced cognitive deficits in mice are improved by subsequent subchronic administration of the novel selective alpha7 nicotinic receptor agonist SSR180711. Biol Psychiatry 63, 92-97.

Hauser, M. J., Isbrandt, D., Roeper, J., 2017. Disturbances of novel object exploration and recognition in a chronic ketamine mouse model of schizophrenia. Behav Brain Res 332, 316-326.

Hayward, A., Adamson, L., Neill, J. C., 2017. Partial agonism at the alpha 7 nicotinic acetylcholine receptor improves attention, impulsive action and vigilance in low attentive rats. European Neuropsychopharmacology 27, 325-335.

Heusser, A. C., Poeppel, D., Ezzyat, Y., Davachi, L., 2016. Episodic sequence memory is supported by a theta-gamma phase code. Nature Neuroscience 19, 1374-+. 
Higgins, G. A., Ballard, T. M., Enderlin, M., Haman, M., Kemp, J. A., 2005. Evidence for improved performance in cognitive tasks following selective NR2B NMDA receptor antagonist pre-treatment in the rat. Psychopharmacology (Berl) 179, 85-98.

Ho, B. C., Andreasen, N. C., Ziebell, S., Pierson, R., Magnotta, V., 2011. Long-term Antipsychotic Treatment and Brain Volumes A Longitudinal Study of First-Episode Schizophrenia. Arch Gen Psychiatry 68, 128-137.

Homayoun, H., Moghaddam, B., 2007. NMDA receptor hypofunction produces opposite effects on prefrontal cortex interneurons and pyramidal neurons. J Neurosci 27, 11496-11500.

Hoptman, M. J., Zuo, X. N., Butler, P. D., Javitt, D. C., D'Angelo, D., Mauro, C. J., Milham, M. P., 2010. Amplitude of low-frequency oscillations in schizophrenia: A resting state fMRI study. Schizophr Res $117,13-20$.

Horiguchi, M., Hannaway, K. E., Adelekun, A. E., Jayathilake, K., Meltzer, H. Y., 2012. Prevention of the phencyclidine-induced impairment in novel object recognition in female rats by coadministration of lurasidone or tandospirone, a 5-HT1A partial agonist. Neuropsychopharmacology $37,2175-2183$.

Horiguchi, M., Meltzer, H. Y., 2012. The role of 5-HT1A receptors in phencyclidine (PCP)-induced novel object recognition (NOR) deficit in rats. Psychopharmacology (Berl) 221, 205-215.

Idris, N., Neill, J., Grayson, B., Bang-Andersen, B., Witten, L. M., Brennum, L. T., Arnt, J., 2010. Sertindole improves sub-chronic PCP-induced reversal learning and episodic memory deficits in rodents: involvement of 5-HT(6) and 5-HT (2A) receptor mechanisms. Psychopharmacology (Berl) 208, 23-36.

Idris, N. F., Repeto, P., Neill, J. C., Large, C. H., 2005. Investigation of the effects of lamotrigine and clozapine in improving reversal-learning impairments induced by acute phencyclidine and $\mathrm{D}$ amphetamine in the rat. Psychopharmacology (Berl) 179, 336-348.

Ishibashi, T., Horisawa, T., Tokuda, K., Ishiyama, T., Ogasa, M., Tagashira, R., Matsumoto, K., Nishikawa, H., Ueda, Y., Toma, S., Oki, H., Tanno, N., Saji, I., Ito, A., Ohno, Y., Nakamura, M., 2010. Pharmacological profile of lurasidone, a novel antipsychotic agent with potent 5-hydroxytryptamine 7 (5-HT7) and 5-HT1A receptor activity. J Pharmacol Exp Ther 334, 171-181.

Jadi, M. P., Behrens, M. M., Sejnowski, T. J., 2016. Abnormal Gamma Oscillations in N-Methyl-DAspartate Receptor Hypofunction Models of Schizophrenia. Biol Psychiatry 79, 716-726.

Jeevakumar, V., Driskill, C., Paine, A., Sobhanian, M., Vakil, H., Morris, B., Ramos, J., Kroener, S., 2015. Ketamine administration during the second postnatal week induces enduring schizophrenialike behavioral symptoms and reduces parvalbumin expression in the medial prefrontal cortex of adult mice. Behav Brain Res 282, 165-175.

Jones, G. H., Marsden, C. A., Robbins, T. W., 1991. Behavioural rigidity and rule-learning deficits following isolation-rearing in the rat: neurochemical correlates. Behav Brain Res 43, 35-50.

Jones, K. M., McDonald, I. M., Bourin, C., Olson, R. E., Bristow, L. J., Easton, A., 2014. Effect of alpha7 nicotinic acetylcholine receptor agonists on attentional set-shifting impairment in rats. Psychopharmacology (Berl) 231, 673-683.

Joyce, J. N., Milian, M. J., 2005. Dopamine D-3 receptor antagonists as therapeutic agents. Drug Discovery Today 10, 917-925. 
Kandratavicius, L., Balista, P. A., Wolf, D. C., Abrao, J., Evora, P. R., Rodrigues, A. J., Chaves, C., MaiaDe-Oliveira, J. P., Leite, J. P., Dursun, S. M., Baker, G. B., Guimaraes, F. S., Hallak, J. E. C., 2015. Effects of nitric oxide-related compounds in the acute ketamine animal model of schizophrenia. BMC Neurosci 16.

Keefe, R. S. E., Bilder, R. M., Davis, S. M., Harvey, P. D., Palmer, B. W., Gold, J. M., Meltzer, H. Y., Green, M. F., Capuano, G., Stroup, T. S., McEvoy, J. P., Swartz, M. S., Roscnheck, R. A., Perkins, D. O., Davis, C. E., Hsiao, J. K., Lieberman, J. A., 2007. Neurocognitive effects of antipsychotic medications in patients with chronic schizophrenia in the CATIE trial. Arch Gen Psychiatry 64, 633-647.

Kim, E. W., Phillips, B. U., Heath, C. J., Cho, S. Y., Kim, H., Sreedharan, J., Song, H. T., Lee, J. E., Bussey, T. J., Kim, C. H., Kim, E., Saksida, L. M., 2017. Optimizing reproducibility of operant testing through reinforcer standardization: identification of key nutritional constituents determining reward strength in touchscreens. Molecular Brain 10.

Kittelberger, K., Hur, E. E., Sazegar, S., Keshavan, V., Kocsis, B., 2012. Comparison of the effects of acute and chronic administration of ketamine on hippocampal oscillations: relevance for the NMDA receptor hypofunction model of schizophrenia. Brain Struct Funct 217, 395-409.

Knuesel, I., Chicha, L., Britschgi, M., Schobel, S. A., Bodmer, M., Hellings, J. A., Toovey, S., Prinssen, E. P., 2014. Maternal immune activation and abnormal brain development across CNS disorders. Nature Reviews Neurology 10, 643-660.

Koh, Y., Shin, K. S., Kim, J. S., Choi, J. S., Kang, D. H., Jang, J. H., Cho, K. H., O'Donnell, B. F., Chung, C. K., Kwon, J. S., 2011. An MEG study of alpha modulation in patients with schizophrenia and in subjects at high risk of developing psychosis. Schizophr Res 126, 36-42.

Korotkova, T., Fuchs, E. C., Ponomarenko, A., von Engelhardt, J., Monyer, H., 2010. NMDA receptor ablation on parvalbumin-positive interneurons impairs hippocampal synchrony, spatial representations, and working memory. Neuron 68, 557-569.

Kos, T., Nikiforuk, A., Rafa, D., Popik, P., 2011. The effects of NMDA receptor antagonists on attentional set-shifting task performance in mice. Psychopharmacology (Berl) 214, 911-921.

Kramer, M. S., Last, B., Getson, A., Reines, S. A., Silva, J. A., Wirshing, W., Conley, R., Allan, E., Cheng, H. Y., ChavezEng, C., 1997. The effects of a selective D-4 dopamine receptor antagonist $(L-745,870)$ in acutely psychotic inpatients with schizophrenia. Arch Gen Psychiatry 54, 567-572.

Lapish, C. C., Ahn, K. C., Chambers, R. A., Ashby, D. M., Ahn, S., Phillips, A. G., 2014. Selective effects of $D$ - and L-govadine in preclinical tests of positive, negative, and cognitive symptoms of schizophrenia. Neuropsychopharmacology 39, 1754-1762.

Large, C. H., Bison, S., Sartori, I., Read, K. D., Gozzi, A., Quarta, D., Antolini, M., Hollands, E., Gill, C. H., Gunthorpe, M. J., Idris, N., Neill, J. C., Alvaro, G. S., 2011. The efficacy of sodium channel blockers to prevent phencyclidine-induced cognitive dysfunction in the rat: potential for novel treatments for schizophrenia. J Pharmacol Exp Ther 338, 100-113.

Laszy, J., Laszlovszky, I., Gyertyan, I., 2005. Dopamine D-3 receptor antagonists improve the learning performance in memory-impaired rats. Psychopharmacology (Berl) 179, 567-575.

Lee, B. H., Kim, Y. K., 2008. Reduced plasma nitric oxide metabolites before and after antipsychotic treatment in patients with schizophrenia compared to controls. Schizophr Res 104, 36-43.

Lega, B. C., Jacobs, J., Kahana, M., 2012. Human hippocampal theta oscillations and the formation of episodic memories. Hippocampus 22, 748-761. 
Leger, M., Alvaro, G., Large, C., Harte, M., Neill, C. J., 2015. AUT6, a novel Kv3 channel modulator, reverses cognitive and neurobiological dysfunction in a rat model of relevance to schizophrenia symptomatology. Eur Neuropsychopharmacol, 25, S480

Leiser, S. C., Bowlby, M. R., Comery, T. A., Dunlop, J., 2009. A cog in cognition: How the alpha 7 nicotinic acetylcholine receptor is geared towards improving cognitive deficits. Pharmacol Ther 122, 302-311.

Lesh, T. A., Niendam, T. A., Minzenberg, M. J., Carter, C. S., 2011. Cognitive control deficits in schizophrenia: mechanisms and meaning. Neuropsychopharmacology 36, 316-338.

Levin, E. D., McClernon, F. J., Rezvani, A. H., 2006. Nicotinic effects on cognitive function: behavioral characterization, pharmacological specification, and anatomic localization. Psychopharmacology (Berl) 184, 523-539.

Lewis, D. A., 2014. Inhibitory neurons in human cortical circuits: substrate for cognitive dysfunction in schizophrenia. Curr Opin Neurobiol 26, 22-26.

Li, J. T., Su, Y. A., Wang, H. L., Zhao, Y. Y., Liao, X. M., Wang, X. D., Si, T. M., 2016. Repeated Blockade of NMDA Receptors During Adolescence Impairs Reversal Learning and Disrupts GABAergic Interneurons in Rat Medial Prefrontal Cortex. Frontiers in Molecular Neuroscience 9.

Liddle, P. 2000. Functional brain imaging of schizophrenia. In The Psychopharmacology of Schizophrenia. ed. Reveley, M.A. \& Deakin, J. F. W. 41-55. New York: Oxford University Press.

Lins, B.R., Phillips, A.G., Howland, JG., 2015. Effects of D- and L-govadine on the disruption of touchscreen object-location paired associates learning in rats by acute MK-801 treatment. 232, 4371-4382.

Lins, B. R., Howland, J. G., 2016. Effects of the metabotropic glutamate receptor 5 positive allosteric modulator CDPPB on rats tested with the paired associates learning task in touchscreen-equipped operant conditioning chambers. Behav Brain Res 301, 152-160.

Lisman, J. E., Jensen, O., 2013. The theta-gamma neural code. Neuron 77, 1002-1016.

Lisman J.E., Coyle J.T., Green R.W., Javitt D.C., Benes .FM., Heckers S., Grace A.A., 2008 Circuit-based framework for understanding neurotransmitter and risk gene interactions in schizophrenia. Trends Neurosci 31(5), 234-242.

Liu, S. K., Fitzgerald, P. B., Daigle, M., Chen, R., Daskalakis, Z. J., 2009. The Relationship Between Cortical Inhibition, Antipsychotic Treatment, and the Symptoms of Schizophrenia. Biol Psychiatry 65, 503-509.

Massi, L., Lagler, M., Hartwich, K., Borhegyi, Z., Somogyi, P., Klausberger, T., 2012. Temporal Dynamics of Parvalbumin-Expressing Axo-axonic and Basket Cells in the Rat Medial Prefrontal Cortex In Vivo. Journal of Neuroscience 32, 16496-16502.

Mayer, J. S., Park, S., 2012. Working memory encoding and false memory in schizophrenia and bipolar disorder in a spatial delayed response task. Journal of Abnormal Psychology 121, 784-794.

McAlonan, K., Brown, V. J., 2003. Orbital prefrontal cortex mediates reversal learning and not attentional set shifting in the rat. Behav Brain Res 146, 97-103. 
McLean, S. L., Grayson, B., Idris, N. F., Lesage, A. S., Pemberton, D. J., Mackie, C., Neill, J. C., 2011. Activation of alpha7 nicotinic receptors improves phencyclidine-induced deficits in cognitive tasks in rats: implications for therapy of cognitive dysfunction in schizophrenia. Eur Neuropsychopharmacol 21, 333-343.

McLean, S. L., Harte, M. K., Neill, J. C., Young, A. M. J., 2017. Dopamine dysregulation in the prefrontal cortex relates to cognitive deficits in the sub-chronic PCP-model for schizophrenia: $\mathrm{A}$ preliminary investigation. J Psychopharmacol 31, 660-666.

McLean S.L., Idris N.F., Woolley M.L., Thomas, D., Neill J.C., 2009a. Role of 5-HT receptor mechanisms in sub-chronic PCP-induced reversal learning deficits in the rat. Psychopharmacology 206(3), 403-414.

McLean, S. L., Idris, N. F., Woolley, M. L., Neill, J. C., 2009b. D(1)-like receptor activation improves PCP-induced cognitive deficits in animal models: Implications for mechanisms of improved cognitive function in schizophrenia. Eur Neuropsychopharmacol 19, 440-450.

McLean, S. L., Idris, N. F., Grayson, B., Gendle, D. F., Mackie, C., Lesage, A. S., Pemberton, D. J., Neill, J. C., 2012. PNU-120596, a positive allosteric modulator of alpha7 nicotinic acetylcholine receptors, reverses a sub-chronic phencyclidine-induced cognitive deficit in the attentional set-shifting task in female rats. J Psychopharmacol 26, 1265-1270.

McLean, S. L., Neill, J. C., Idris, N. F., Marston, H. M., Wong, E. H., Shahid, M., 2010. Effects of asenapine, olanzapine, and risperidone on psychotomimetic-induced reversal-learning deficits in the rat. Behav Brain Res 214, 240-247.

McQuail, J. A., Beas, B. S., Kelly, K. B., Simpson, K. L., Frazier, C. J., Setlow, B., Bizon, J. L., 2016. NR2AContaining NMDARs in the Prefrontal Cortex Are Required for Working Memory and Associated with Age-Related Cognitive Decline. Journal of Neuroscience 36, 12537-12548.

Meltzer, H. Y., Rajagopal, L., Huang, M., Oyamada, Y., Kwon, S., Horiguchi, M., 2013. Translating the $\mathrm{N}$-methyl-D-aspartate receptor antagonist model of schizophrenia to treatments for cognitive impairment in schizophrenia. International Journal of Neuropsychopharmacology 16, 2181-2194.

Meltzer, J. A., Zaveri, H. P., Goncharova, II, Distasio, M. M., Papademetris, X., Spencer, S. S., Spencer, D. D., Constable, R. T., 2008. Effects of working memory load on oscillatory power in human intracranial EEG. Cereb Cortex 18, 1843-1855.

Millan, M. J., Gobert, A., Newman-Tancredi, A., Lejeune, F., Cussac, D., Rivet, J. M., Audinot, V., Dubuffet, T., Lavielle, G., 2000. S33084, a novel, potent, selective, and competitive antagonist at dopamine D-3-receptors: I. Receptorial, electrophysiological and neurochemical profile compared with GR218,231 and L741,626. Journal of Pharmacology and Experimental Therapeutics 293, 10481062.

Minzenberg, M. J., Firl, A. J., Yoon, J. H., Gomes, G. C., Reinking, C., Carter, C. S., 2010. Gamma Oscillatory Power is Impaired During Cognitive Control Independent of Medication Status in FirstEpisode Schizophrenia. Neuropsychopharmacology 35, 2590-2599.

Miyauchi, M., Neugebauer, N. M., Meltzer, H. Y., 2017. Dopamine D-4 receptor stimulation contributes to novel object recognition: Relevance to cognitive impairment in schizophrenia. J Psychopharmacol 31, 442-452. 
Miyauchi, M., Neugebauer, N. M., Oyamada, Y., Meltzer, H. Y., 2016. Nicotinic receptors and lurasidone-mediated reversal of phencyclidine-induced deficit in novel object recognition. Behav Brain Res 301, 204-212.

Molina, L. A., Skelin, I., Gruber, A. J., 2014. Acute NMDA receptor antagonism disrupts synchronization of action potential firing in rat prefrontal cortex. Plos One 9, e85842.

Mulert, C., Kirsch, V., Pascual-Marqui, R., McCarley, R. W., Spencer, K. M., 2011. Long-range synchrony of gamma oscillations and auditory hallucination symptoms in schizophrenia. Int J Psychophysiol 79, 55-63.

Munafo, M., Neill, J., 2016. Null is beautiful: On the importance of publishing null results. J Psychopharmacol 30, 585-585.

Neill, J. C., Barnes, S., Cook, S., Grayson, B., Idris, N. F., McLean, S. L., Snigdha, S., Rajagopal, L., Harte, M. K., 2010. Animal models of cognitive dysfunction and negative symptoms of schizophrenia: focus on NMDA receptor antagonism. Pharmacol Ther 128, 419-432.

Neill, J. C., Grayson, B., Kiss, B., Gyertyan, I., Ferguson, P., Adham, N., 2016. Effects of cariprazine, a novel antipsychotic, on cognitive deficit and negative symptoms in a rodent model of schizophrenia symptomatology. Eur. Neuropsychopharmacology, 26(1): 3-14.

Neill, J. C., Grayson, B., Kiss, B., Gyertyan, I., Ferguson, P., Adham, N., 2016. Effects of cariprazine, a novel antipsychotic, on cognitive deficit and negative symptoms in a rodent model of schizophrenia symptomatology. European Neuropsychopharmacology 26, 3-14.

Neill, J. C., Harte, M. K., Haddad, P. M., Lydall, E. S., Dwyer, D. M., 2014. Acute and chronic effects of NMDA receptor antagonists in rodents, relevance to negative symptoms of schizophrenia: a translational link to humans. Eur Neuropsychopharmacol 24, 822-835.

Nikiforuk, A., Golembiowska, K., Popik, P., 2010. Mazindol attenuates ketamine-induced cognitive deficit in the attentional set shifting task in rats. European Neuropsychopharmacology 20, 37-48.

Nikiforuk A., Popik P., 2012. Effects of quetiapine and sertindole on subchronic ketamine-induced deficits in attentional set-shifting in rats. Psychopharmacology (Berl) 220(1), 65-74.

Nikiforuk, A., Holuj, M., Kos, T., Popik, P., 2016a. The effects of a 5-HT5A receptor antagonist in a ketamine-based rat model of cognitive dysfunction and the negative symptoms of schizophrenia. Neuropharmacology 105, 351-360.

Nikiforuk, A., Kos, T., Holuj, M., Potasiewicz, A., Popik, P., 2016b. Positive allosteric modulators of alpha 7 nicotinic acetylcholine receptors reverse ketamine-induced schizophrenia-like deficits in rats. Neuropharmacology 101, 389-400.

Nowland, M. H., Hugunin, K. M. S., Rogers, K. L., 2011. Effects of Short-Term Fasting in Male SpragueDawley Rats. Comparative Medicine 61, 138-144.

Nuechterlein, K. H., Barch, D. M., Gold, J. M., Goldberg, T. E., Green, M. F., Heaton, R. K., 2004. Identification of separable cognitive factors in schizophrenia. Schizophr Res 72, 29-39.

Numan, R., 2015. A Prefrontal-Hippocampal Comparator for Goal-Directed Behavior: The Intentional Self and Episodic Memory. Front Behav Neurosci 9.

Nyhus, E., Curran, T., 2010. Functional role of gamma and theta oscillations in episodic memory. Neurosci Biobehav Rev 34, 1023-1035. 
Oomen, C. A., Hvoslef-Eide, M., Heath, C. J., Mar, A. C., Horner, A. E., Bussey, T. J., Saksida, L. M., 2013. The touchscreen operant platform for testing working memory and pattern separation in rats and mice. Nature Protocols 8, 2006-2021.

Orellana, G. P., Pena, M., Slachevsky, A., 2012. Executive Attention Impairment in First Episode of Schizophrenia. Schizophr Res 136, S148-S149.

Palenicek, T., Fujakova, M., Brunovsky, M., Balikova, M., Horacek, J., Gorman, I., Tyls, F., Tislerova, B., Sos, P., Bubenikova-Valesova, V., Hoschl, C., Krajca, V., 2011. Electroencephalographic spectral and coherence analysis of ketamine in rats: correlation with behavioral effects and pharmacokinetics. Neuropsychobiology 63, 202-218.

Pantelis, C., Barber, F. Z., Barnes, T. R. E., Nelson, H. E., Owen, A. M., Robbins, T. W., 1999. Comparison of set-shifting ability in patients with chronic schizophrenia and frontal lobe damage. Schizophr Res 37, 251-270.

Pantelis, C., Barnes, T. R. E., Nelson, H. E., Tanner, S., Weatherley, L., Owen, A. M., Robbins, T. W., 1997. Frontal-striatal cognitive deficits in patients with chronic schizophrenia. Brain 120, 1823-1843.

Pedersen, C. S., Goetghebeur, P., Dias, R., 2009. Chronic infusion of PCP via osmotic mini-pumps: A new rodent model of cognitive deficit in schizophrenia characterized by impaired attentional setshifting (ID/ED) performance. Journal of Neuroscience Methods 185, 66-69.

Peters, S. M., Pothuizen, H. H. J., Spruijt, B. M., 2015. Ethological concepts enhance the translational value of animal models. European Journal of Pharmacology 759, 42-50.

Pichat, P., Bergis, O. E., Terranova, J. P., Urani, A., Duarte, C., Santucci, V., Gueudet, C., Voltz, C., Steinberg, R., Stemmelin, J., Oury-Donat, F., Avenet, P., Griebel, G., Scatton, B., 2007. SSR180711, a novel selective alpha7 nicotinic receptor partial agonist: (II) efficacy in experimental models predictive of activity against cognitive symptoms of schizophrenia. Neuropsychopharmacology 32 , 17-34.

Pitsikas, N., Sakellaridis, N., 2006. Crocus sativus L. extracts antagonize memory impairments in different behavioural tasks in the rat. Behav Brain Res 173, 112-115.

Pitsikas, N., Zisopoulou, S., Tarantilis, P. A., Kanakis, C. D., Polissiou, M. G., Sakellaridis, N., 2007. Effects of the active constituents of Crocus sativus L., crocins on recognition and spatial rats' memory. Behav Brain Res 183, 141-146.

Pittman-Polletta, B. R., Kocsis, B., Vijayan, S., Whittington, M. A., Kopell, N. J., 2015. Brain rhythms connect impaired inhibition to altered cognition in schizophrenia. Biol Psychiatry 77, 1020-1030.

Podda, G., Woolley-Roberts, M., Neill, J. C., Piercy, C., Grayson, B., 2016. Cannabidol restores cognitive and social behaviour deficits in a validated animal model for schizophrenia.J Psychopharmacology,30(8):A21.

Prast, H., Philippu, A., 2001. Nitric oxide as modulator of neuronal function. Progress in Neurobiology 64, 51-68.

Pratt, J.A., Winchester, C., Egerton, A., Cochran, S.M., Morris, B.J., 2008. Modelling prefrontal cortex deficits in schizophrenia: implications for treatment. Br. J. Pharmacol. 153 Suppl 1, S465-470.

Rajagopal, L., Massey, B. W., Huang, M., Oyamada, Y., Meltzer, H. Y., 2014. The novel object recognition test in rodents in relation to cognitive impairment in schizophrenia. Current Pharmaceutical Design 20, 5104-5114. 
Rajagopal, L., Massey, B. W., Michael, E., Meltzer, H. Y., 2016. Serotonin (5-HT)(1A) receptor agonism and 5-HT7 receptor antagonism ameliorate the subchronic phencyclidine-induced deficit in executive functioning in mice. Psychopharmacology (Berl) 233, 649-660.

Ramirez, J., Garnica, R., Boll, M. C., Montes, S., Rios, C., 2004. Low concentration of nitrite and nitrate in the cerebrospinal fluid from schizophrenic patients: a pilot study. Schizophr Res 68, 357361.

Reavill, C., Taylor, S. G., Wood, M. D., Ashmeade, T., Austin, N. E., Avenell, K. Y., Boyfield, I., Branch, C. L., Cilia, J., Coldwell, M. C., Hadley, M. S., Hunter, A. J., Jeffrey, P., Jewitt, F., Johnson, C. N., Jones, D. N., Medhurst, A. D., Middlemiss, D. N., Nash, D. J., Riley, G. J., Routledge, C., Stemp, G., Thewlis, K. M., Trail, B., Vong, A. K., Hagan, J. J., 2000. Pharmacological actions of a novel, high-affinity, and selective human D3 receptor antagonist, SB-277011-A. J Pharmacol Exp Ther 294:1154-1165.

Redrobe, J. P., Elster, L., Frederiksen, K., Bundgaard, C., de Jong, I. E. M., Smith, G. P., Bruun, A. T., Larsen, P. H., Didriksen, M., 2012. Negative modulation of GABA(A) alpha 5 receptors by RO4938581 attenuates discrete sub-chronic and early postnatal phencyclidine (PCP)-induced cognitive deficits in rats. Psychopharmacology (Berl) 221, 451-468.

Reynolds, G. P., Neill, J. C., 2016. Modelling the cognitive and neuropathological features of schizophrenia with phencyclidine. J Psychopharmacol 30, 1141-1144.

Rezvani A.H., Levin ED., 2003. Nicotinic-glutamatergic interactions and attentional performance on an operant visual signal detection task in female rats. Eur J Pharmacol 465, 83-90.

Rezvani, A. H., Cauley, M. C., Johnson, E. C., Gatto, G. J., Levin, E. D., 2012. Effects of AZD3480, a neuronal nicotinic acetylcholine receptor agonist, and donepezil on dizocilpine-induced attentional impairment in rats. Psychopharmacology (Berl) 223, 251-258.

Roopun, A. K., Cunningham, M. O., Racca, C., Alter, K., Traub, R. D., Whittington, M. A., 2008. Regionspecific changes in gamma and beta2 rhythms in NMDA receptor dysfunction models of schizophrenia. Schizophr Bull 34, 962-973.

Rotaru, D. C., Yoshino, H., Lewis, D. A., Ermentrout, G. B., Gonzalez-Burgos, G., 2011. Glutamate receptor subtypes mediating synaptic activation of prefrontal cortex neurons: relevance for schizophrenia. J Neurosci 31, 142-156.

Sabbagh, J. J., Murtishaw, A. S., Bolton, M. M., Heaney, C. F., Langhardt, M., Kinney, J. W., 2013. Chronic ketamine produces altered distribution of parvalbumin-positive cells in the hippocampus of adult rats. Neuroscience Letters 550, 69-74.

Sahin, C., Doostdar, N., Neill, J. C., 2016. Towards the development of improved tests for negative symptoms of schizophrenia in a validated animal model. Behav Brain Res 312, 93-101.

Saleem, M. M., Harte, M. K., Marshall, K. M., Scally, A., Brewin, A., Neill, J. C., 2013. First episode psychosis patients show impaired cognitive function - a study of a South Asian population in the UK. J Psychopharmacol 27, 366-373.

Sarter, M., Parikh, V., Howe, W. M., 2009. nAChR agonist-induced cognition enhancement: Integration of cognitive and neuronal mechanisms. Biochem Pharmacol 78, 658-667.

Seeman, P., Vantol, H. H. M., 1994. Dopamine-Receptor Pharmacology. Trends Pharmacol Sci 15, 264-270. 
Shahid, M., Walker, G. B., Zorn, S. H., Wong, E. H. F., 2009. Asenapine: a novel psychopharmacologic agent with a unique human receptor signature. J Psychopharmacol 23, 65-73.

Shirvalkar, P. R., Rapp, P. R., Shapiro, M. L., 2010. Bidirectional changes to hippocampal thetagamma comodulation predict memory for recent spatial episodes. Proceedings of the National Academy of Sciences of the United States of America 107, 7054-7059.

Shiraishi, E., Suzuki, K., Harada, A., Suzuki, N., Kimura, H., 2016. The Phosphodiesterase 10A Selective Inhibitor TAK-063 Improves Cognitive Functions Associated with Schizophrenia in Rodent Models. J Pharmacol Exp Ther 356, 587-595.

Short, B., Fong, J., Galvez, V., Shelker, W., Loo, C. K., 2017. Side-effects associated with ketamine use in depression: a systematic review. Lancet Psychiatry.

Snigdha, S., Idris, N., Grayson, B., Shahid, M., Neill, J. C., 2011a. Asenapine improves phencyclidineinduced object recognition deficits in the rat: evidence for engagement of a dopamine D1 receptor mechanism. Psychopharmacology (Berl) 214, 843-853.

Snigdha, S., Neill, J. C., McLean, S. L., Shemar, G. K., Cruise, L., Shahid, M., Henry, B., 2011b. Phencyclidine (PCP)-induced disruption in cognitive performance is gender-specific and associated with a reduction in brain-derived neurotrophic factor (BDNF) in specific regions of the female rat brain. J Mol Neurosci 43, 337-345.

Sohal, V. S., Zhang, F., Yizhar, O., Deisseroth, K., 2009. Parvalbumin neurons and gamma rhythms enhance cortical circuit performance. Nature 459, 698-702.

Song, C., Murray, T. A., Kimura, R., Wakui, M., Ellsworth, K., Javedan, S. P., Marxer-Miller, S., Lukas, R. J., Wu, J., 2005. Role of alpha7-nicotinic acetylcholine receptors in tetanic stimulation-induced gamma oscillations in rat hippocampal slices. Neuropharmacology 48, 869-880.

Sood, P., Idris, N. F., Cole, S., Grayson, B., Neill, J. C., Young, A. M., 2011. PD168077, a D(4) receptor agonist, reverses object recognition deficits in rats: potential role for $D(4)$ receptor mechanisms in improving cognitive dysfunction in schizophrenia. J Psychopharmacol 25, 792-800.

Spencer, K. M., Nestor, P. G., Niznikiewicz, M. A., Salisbury, D. F., Shenton, M. E., McCarley, R. W., 2003. Abnormal neural synchrony in schizophrenia. J Neurosci 23, 7407-7411.

Spencer, K. M., Nestor, P. G., Perlmutter, R., Niznikiewicz, M. A., Klump, M. C., Frumin, M., Shenton, M. E., McCarley, R. W., 2004. Neural synchrony indexes disordered perception and cognition in schizophrenia. Proc Natl Acad Sci U S A 101, 17288-17293.

Szlachta, M., Pabian, P., Kusmider, M., Solich, J., Kolasa, M., Zurawek, D., Dziedzicka-Wasylewska, M., Faron-Gorecka, A., 2017. Effect of clozapine on ketamine-induced deficits in attentional set shift task in mice. Psychopharmacology (Berl) 234, 2103-2112.

Talpos, J., Aerts, N., Waddell, J., Steckler, T., 2015. MK-801 and amphetamine result in dissociable profiles of cognitive impairment in a rodent paired associates learning task with relevance for schizophrenia. Psychopharmacology (Berl) 232, 3911-3920.

Talpos, J. C., 2017. Symptomatic thinking: the current state of Phase III and IV clinical trials for cognition in schizophrenia. Drug Discovery Today 22, 1017-1026.

Tamminga, C. A., 2006. The neurobiology of cognition in schizophrenia. J Clin Psychiatry 67 Suppl 9, 9-13; discussion 36-42. 
Thomsen, M. S., Christensen, D. Z., Hansen, H. H., Redrobe, J. P., Mikkelsen, J. D., 2009. alpha(7) Nicotinic acetylcholine receptor activation prevents behavioral and molecular changes induced by repeated phencyclidine treatment. Neuropharmacology 56, 1001-1009.

Timic Stamenic, T., Joksimovic, S., Biawat, P., Stankovic, T., Markovic, B., Cook, J.M., Savic, M.M., 2015. Negative modulation of alpha(5) GABAA receptors in rats may partially prevent memory impairment induced by MK-801, but not amphetamine- or MK-801-elicited hyperlocomotion. J. Psychopharmacol. 29, 1013-1024.

Trevlopoulou, A., Touzlatzi, N., Pitsikas, N., 2016. The nitric oxide donor sodium nitroprusside attenuates recognition memory deficits and social withdrawal produced by the NMDA receptor antagonist ketamine and induces anxiolytic-like behaviour in rats. Psychopharmacology (Berl) 233, 1045-1054.

Turner, C. P., DeBenedetto, D., Ware, E., Stowe, R., Lee, A., Swanson, J., Walburg, C., Lambert, A., Lyle, M., Desai, P., Liu, C., 2010. Postnatal exposure to MK801 induces selective changes in GAD67 or parvalbumin. Experimental Brain Research 201, 479-488.

Tyson, P. J., Laws, K. R., Roberts, K. H., Mortimer, A. M., 2004. Stability of set-shifting and planning abilities in patients with schizophrenia. Psychiatry Res 129, 229-239.

Uhlhaas, P. J., Linden, D. E., Singer, W., Haenschel, C., Lindner, M., Maurer, K., Rodriguez, E., 2006. Dysfunctional long-range coordination of neural activity during Gestalt perception in schizophrenia. J Neurosci 26, 8168-8175.

Uhlhaas, P. J., Singer, W., 2010. Abnormal neural oscillations and synchrony in schizophrenia. Nat Rev Neurosci 11, 100-113.

Uhlhaas, P. J., Singer, W., 2013. High-frequency oscillations and the neurobiology of schizophrenia. Dialogues Clin Neurosci 15, 301-313.

Vernon, A. C., Crum, W. R., Lerch, J. P., Chege, W., Natesan, S., Modo, M., Cooper, J. D., Williams, S. C., Kapur, S., 2014. Reduced cortical volume and elevated astrocyte density in rats chronically treated with antipsychotic drugs-linking magnetic resonance imaging findings to cellular pathology. Biol Psychiatry 75, 982-990.

Wang, C. Z., Yang, S. F., Xia, Y., Johnson, K. M., 2008. Postnatal phencyclidine administration selectively reduces adult cortical parvalbumin-containing interneurons. Neuropsychopharmacology $33,2442-2455$.

Wang, X. J., 2010. Neurophysiological and Computational Principles of Cortical Rhythms in Cognition. Physiological Reviews 90, 1195-1268.

Wong, A. H. C., Van Tol, H. H. M., 2003. The dopamine D-4 receptors and mechanisms of antipsychotic atypicality. Prog Neuropsychopharmacol Biol Psychiatry 27, 1091-1099.

Woolley, M. L., Waters, K. A., Reavill, C., Bull, S., Lacroix, L. R., Martyn, A. J., Hutcheson, D. M., Valerio, E., Bate, S., Jones, D. N. C., Dawson, L. A., 2008. Selective dopamine D(4) receptor agonist (A412997) improves cognitive performance and stimulates motor activity without influencing rewardrelated behaviour in rat. Behav Pharmacol 19, 765-776.

Xing, G. Q., Chavko, M., Zhang, L. X., Yang, S. T., Post, R. M., 2002. Decreased calcium-dependent constitutive nitric oxide synthase (cNOS) activity in prefrontal cortex in schizophrenia and depression. Schizophr Res 58, 21-30. 
Xu, H., Jeong, H. Y., Tremblay, R., Rudy, B., 2013. Neocortical Somatostatin-Expressing GABAergic Interneurons Disinhibit the Thalamorecipient Layer 4. Neuron 77, 155-167.

Yanagi M., Joho R.H., Southcott S.A., Shukla A.A., Ghose S., Tamminga C.A., 2014. Kv3.1-containing $\mathrm{K}(+)$ channels are reduced in untreated schizophrenia and normalized with antipsychotic drugs. Mol Psychiatry 19(5), 573-579.

Yang, C., Han, M., Zhang, J. C., Ren, Q., Hashimoto, K., 2016. Loss of parvalbumin-immunoreactivity in mouse brain regions after repeated intermittent administration of esketamine, but not Rketamine. Psychiatry Res 239, 281-283.

Young, A. M. J., Stubbendorff, C., Valencia, M., Gerdjikov, T. V., 2015. Disruption of medial prefrontal synchrony in the subchronic phencyclidine model of schizophrenia in rats. Neuroscience 287, 157163. 
Table 3

Summary of compounds showing efficacy in more than one paradigm, assessing more than one domain of CIAS and in a biomarker study.

\begin{tabular}{|c|c|c|c|}
\hline $\begin{array}{c}\text { Drug/ } \\
\text { compound }\end{array}$ & NOR & ASST & RL \\
\hline $\begin{array}{l}\text { SSR180711, } \\
\text { selective } \alpha 7 \\
\text { nAChR partial } \\
\text { agonist }\end{array}$ & $\begin{array}{l}0.3 \text { and } 1 \mathrm{mg} / \mathrm{kg} \\
\text { SSR } 180711 \text { in male Wistar } \\
\text { acute MK-801 treated rats } \\
\text { (Pichat } \text { et al., 2007); } \\
3 \mathrm{mg} / \mathrm{kg} \mathrm{scSSR} 180711 \text { in } \\
\text { male ICR scPCP treated } \\
\text { mice (Hashimoto } \text { et al., } \\
\text { 2008) }\end{array}$ & $\begin{array}{l}10 \mathrm{mg} / \mathrm{kg} \text { SSR180711 in } \\
\text { male Wistar acute MK-801 } \\
\text { treated rats (Jones at al., } \\
\text { 2014) }\end{array}$ & \\
\hline $\begin{array}{l}\text { PNU-282987, } \\
\text { selective } \alpha 7 \\
\text { nAChR full } \\
\text { agonist }\end{array}$ & $\begin{array}{l}10 \mathrm{mg} / \mathrm{kg} \text { scPNU-282987 in } \\
\text { female Lister Hooded } \\
\text { scPCP treated rats (McLean } \\
\text { et al., 2011); } \\
1 \mathrm{mg} / \mathrm{kg} \text { PNU-282987 in } \\
\text { female Long Evans scPCP } \\
\text { treated rats (Miyauchi et al., } \\
2016 \text { ) }\end{array}$ & $\begin{array}{l}3,10 \mathrm{mg} / \mathrm{kg} \text { PNU-282987 in } \\
\text { male Wistar acute MK-801 } \\
\text { treated rats (Jones at al., } \\
\text { 2014) }\end{array}$ & \\
\hline $\begin{array}{l}\text { PNU-120596, } \\
\alpha 7-n A C h R s \\
\text { PAM type I }\end{array}$ & $\begin{array}{l}1 \text { and } 3 \mathrm{mg} / \mathrm{kg} \text { PNU-120596 } \\
\text { in male Sprague-Dawley } \\
\text { acute ketamine treated rats } \\
\text { (Nikiforuk et al., 2016b) }\end{array}$ & $\begin{array}{l}0.3 \text { and } 1 \mathrm{mg} / \mathrm{kg} \text { PNU- } \\
120596 \text { in male Sprague- } \\
\text { Dawley acute ketamine } \\
\text { treated rats (Nikiforuk et } \\
\text { al., } 2016 \mathrm{~b}) ; \\
10 \mathrm{mg} / \mathrm{kg} \text { PNU-120596 in } \\
\text { female Lister Hooded } \\
\text { scPCP treated rats (McLean } \\
\text { et al., 2012) }\end{array}$ & \\
\hline $\begin{array}{l}\text { CCMI, } \alpha 7- \\
\text { nAChR PAM } \\
\text { type II }\end{array}$ & $\begin{array}{l}0.3 \text { and } 1 \mathrm{mg} / \mathrm{kg} \text { CCMI in } \\
\text { male Sprague-Dawley acute } \\
\text { ketamine treated rats } \\
\text { (Nikiforuk } \text { et al., 2016b) }\end{array}$ & $\begin{array}{l}0.3 \text { and } 1 \mathrm{mg} / \mathrm{kg} \text { CCMI in } \\
\text { male Sprague-Dawley acute } \\
\text { ketamine treated rats } \\
\text { (Nikiforuk et al., 2016b) }\end{array}$ & \\
\hline $\begin{array}{l}\text { Galantamine, } \\
\text { AChE inhibitor } \\
\text { nAChRs } \\
\text { allosteric } \\
\text { modulator }\end{array}$ & $\begin{array}{l}1 \text { and } 3 \mathrm{mg} / \mathrm{kg} \text { galantamine } \\
\text { in male Sprague-Dawley } \\
\text { acute ketamine treated rats } \\
\text { (Nikiforuk } \text { et al., 2016b) }\end{array}$ & $\begin{array}{l}3 \mathrm{mg} / \mathrm{kg} \text { galantamine in } \\
\text { male Sprague-Dawley acute } \\
\text { ketamine treated rats } \\
\text { (Nikiforuk et al., 2016b) }\end{array}$ & \\
\hline $\begin{array}{l}\text { A-582941, } \\
\text { orthosteric } \alpha 7- \\
\text { nAChR agonist }\end{array}$ & $\begin{array}{l}0.3 \text { and } 1 \mathrm{mg} / \mathrm{kg} \mathrm{A-} \\
582941 \mathrm{in} \text { male Sprague- } \\
\text { Dawley acute ketamine } \\
\text { treated rats (Nikiforuk et } \\
\text { al., 2016b) }\end{array}$ & $\begin{array}{l}0.3 \text { and } 3 \mathrm{mg} / \mathrm{kg} \mathrm{A-} \\
582941 \mathrm{in} \text { male Sprague- } \\
\text { Dawley acute ketamine } \\
\text { treated rats (Nikiforuk et } \\
\text { al., 2016b) }\end{array}$ & \\
\hline $\begin{array}{l}\text { Lurasidone, 5- } \\
\mathrm{HT}_{2 \mathrm{~A}}, 5-\mathrm{HT}_{7} \\
\mathrm{D}_{2} \text { antagonist, } \\
\text { and } 5-\mathrm{HT}_{1 \mathrm{~A}}\end{array}$ & $\begin{array}{l}0.1 \mathrm{mg} / \mathrm{kg} \text { lurasidone in } \\
\text { female Long-Evans scPCP } \\
\text { treated rats (Horiguchi \& } \\
\text { Meltzer, 2012); }\end{array}$ & & $\begin{array}{l}3 \mathrm{mg} / \mathrm{kg} \text { lurasidone in male } \\
\mathrm{C} 57 \mathrm{BL} / 6 \mathrm{~J} \mathrm{scPCP} \text { treated } \\
\text { mice (Rajagopal } \text { et al., }\end{array}$ \\
\hline
\end{tabular}




\begin{tabular}{|c|c|c|c|}
\hline $\begin{array}{c}\text { Drug/ } \\
\text { compound }\end{array}$ & NOR & ASST & RL \\
\hline $\begin{array}{l}\text { receptor partial } \\
\text { agonist AAPD }\end{array}$ & $\begin{array}{l}1 \mathrm{mg} / \mathrm{kg} \text { sc-lurasidone in } \\
\text { female Long-Evans scPCP } \\
\text { treated rats (Horiguchi et al, } \\
2012 \text { ) }\end{array}$ & & 2016) \\
\hline $\begin{array}{l}\text { SB-699551, 5- } \\
\mathrm{HT}_{5 \mathrm{~A}} \text { receptor } \\
\text { antagonist }\end{array}$ & $\begin{array}{l}1 \text { and } 3 \mathrm{mg} / \mathrm{kg} \text { in male } \\
\text { Sprague-Dawley acute } \\
\text { ketamine treated rats } \\
\text { (Nikiforuk } \text { et al., 2016a) }\end{array}$ & $\begin{array}{l}0.3,1 \text { and } 3 \mathrm{mg} / \mathrm{kg} \text { in male } \\
\text { Sprague-Dawley acute } \\
\text { ketamine treated rats } \\
\text { (Nikiforuk } \text { et al., 2016a) }\end{array}$ & \\
\hline $\begin{array}{l}\text { Clozapine, } \mathrm{D}_{4} \\
\text { antagonist }\end{array}$ & $\begin{array}{l}0.1 \mathrm{mg} / \mathrm{kg} \text { clozapine in } \\
\text { female Lister Hooded } \\
\text { scPCP treated rats } \\
\text { (Miyauchi } \text { et al., 2017) }\end{array}$ & $\begin{array}{l}0.3 \mathrm{mg} / \mathrm{kg} \text { clozapine in male } \\
\mathrm{C} 57 \mathrm{Bl} / 6 \mathrm{~J} \text { acute ketamine } \\
\text { treated mice (Szlachta } \text { et al., } \\
2017) ; \\
0.3 \mathrm{mg} / \mathrm{kg} \text { sc-clozapine in } \\
\text { male } \mathrm{C} 57 \mathrm{Bl} / 6 \mathrm{~J} \text { sc-ketamine } \\
\text { treated mice (Szlachta et al., } \\
2017) ; \\
5 \mathrm{mg} / \mathrm{kg} \text { clozapine in male } \\
\text { Wistar acute MK-801 } \\
\text { treated rats (Jones at al., } \\
\text { 2014) }\end{array}$ & \\
\hline $\begin{array}{l}\text { Cariprazine, } \\
\mathrm{D}_{3} / \mathrm{D}_{2} \text { receptor } \\
\text { partial agonist }\end{array}$ & $\begin{array}{l}0.05,0.1 \mathrm{mg} / \mathrm{kg} \text { cariprazine } \\
\text { in female Lister Hooded } \\
\text { scPCP treated rats (Neill et } \\
\text { al., 2016) }\end{array}$ & & $\begin{array}{l}0.1,0.25 \mathrm{mg} / \mathrm{kg} \text { cariprazine } \\
\text { in female Lister Hooded } \\
\mathrm{scPCP} \text { treated rats (Neill et } \\
\text { al., 2016) }\end{array}$ \\
\hline $\begin{array}{l}\text { RO4938581, } \\
\alpha 5 \text { GABAA } \\
\text { receptors } \\
\text { negative } \\
\text { modulator }\end{array}$ & $\begin{array}{l}1 \mathrm{mg} / \mathrm{kg} \mathrm{RO} 4938581 \mathrm{in} \\
\text { male Lister Hooded scPCP } \\
\text { treated rats (Redrobe et al., } \\
2012 \text { ) - } \\
\text { scPCP-induced deficit in } \\
\text { PV interneurons }\end{array}$ & $\begin{array}{l}1 \mathrm{mg} / \mathrm{kg} \mathrm{RO} 4938581 \mathrm{in} \\
\text { male Lister Hooded scPCP } \\
\text { treated rats (Redrobe } \text { et al., } \\
2012 \text { ) - } \\
\text { scPCP-induced deficit in } \\
\text { PV interneurons }\end{array}$ & \\
\hline $\begin{array}{l}\text { AUT00206, } \\
\text { selective } \\
\text { Kv3.1/3.2 } \\
\text { channel positive } \\
\text { modulator }\end{array}$ & $\begin{array}{l}60 \mathrm{mg} / \mathrm{kg} \text { AUT00206 in } \\
\text { female Lister Hooded } \\
\text { scPCP treated (Leger } \text { et al., } \\
\text { 2015; Cadinu } \text { et al., 2016) - } \\
\text { scPCP-induced deficit in } \\
\text { PV interneurons }\end{array}$ & $\begin{array}{l}60 \mathrm{mg} / \mathrm{kg} \text { scAUT00206 in } \\
\text { female Lister Hooded } \\
\text { scPCP treated (Cadinu } \text { et } \\
\text { al., 2016) - } \\
\text { scPCP-induced deficit in } \\
\text { PV interneurons }\end{array}$ & \\
\hline
\end{tabular}

sc: sub-chronic; NOR: novel object recognition; ASST: attentional set shifting task; RL: reversal learning; PV: parvalbumin 
Table 1

Experimental details in NOR performance in NMDAR antagonist rodent models and effects of pharmacological agents

\begin{tabular}{|c|c|c|c|c|c|c|}
\hline Receptor target & Drug/compound administered & $\begin{array}{l}\text { NMDAR model and } \\
\text { treatment }\end{array}$ & $\begin{array}{l}\text { Gender, Strain, } \\
\text { Age or weight at } \\
\text { time of testing }\end{array}$ & ITI & $\begin{array}{l}\text { Effect on NOR } \\
\text { performance }\end{array}$ & Reference \\
\hline \multirow[t]{2}{*}{$\begin{array}{l}\text { Nicotinic } \\
\text { acetylcholine } \\
\text { receptors } \\
\text { (nAChRs) }\end{array}$} & $\begin{array}{l}\text { SSR180711 (4-bromophenyl } \\
\text { 1,4diazabicyclo(3.2.2) nonane-4- } \\
\text { carboxylate, monohydrochloride), } \\
\text { selective } \alpha 7 \mathrm{nAChR} \text { partial } \\
\text { agonist, } 0.3 \text { and } 1 \mathrm{mg} / \mathrm{kg} \text { p.o., } \\
\text { acute, (co-administered with MK- } \\
801)\end{array}$ & $\begin{array}{l}\text { Acute MK-801, } 0.1 \\
\text { mg/kg, i.p., post- } \\
\text { acquisition }\end{array}$ & $\begin{array}{l}\text { Male Wistar rats, } \\
180-350 \mathrm{~g}\end{array}$ & $1 \mathrm{hr}$ & $\begin{array}{l}\downarrow \mathrm{MK}-801 \text { treated rats } \\
\uparrow 0.3 \text { and } 1 \mathrm{mg} / \mathrm{kg} \\
\mathrm{SSR} 180711 \mathrm{in} \mathrm{MK}- \\
801 \text { treated rats }\end{array}$ & $\begin{array}{l}\text { (Pichat et al., } \\
\text { 2007) }\end{array}$ \\
\hline & $\begin{array}{l}\text { WYE-103914 (1-[6-(4- } \\
\text { fluorophenyl)pyridin-3-yl]-3-(4- } \\
\text { piperidin-1-ylbutyl), selective } \alpha 7 \\
\text { nAChR partial agonist, } 0.3-30 \\
\text { mg/kg p.o., acute, } 60 \text { min prior to } \\
\text { acquisition }\end{array}$ & $\begin{array}{l}\text { Acute } \mathrm{MK}-801,0.03 \\
\mathrm{mg} / \mathrm{kg}, \text { i.p., } 30 \mathrm{~min} \\
\text { prior to acquisition }\end{array}$ & $\begin{array}{l}\text { Male Long Evans } \\
\text { rats }(\sim 250 \mathrm{~g})\end{array}$ & $1 \mathrm{hr}$ & $\begin{array}{l}\downarrow \mathrm{MK}-801 \text { treated rats } \\
\uparrow 3 \text { and } 10 \mathrm{mg} / \mathrm{kg} \\
\text { WYE- } 103914 \text { in MK- } \\
801 \\
\text { treated rats }\end{array}$ & $\begin{array}{l}\text { (Ghiron et al., } \\
\text { 2010) }\end{array}$ \\
\hline
\end{tabular}




\begin{tabular}{|c|c|c|c|c|c|c|}
\hline Receptor target & Drug/compound administered & $\begin{array}{c}\text { NMDAR model and } \\
\text { treatment }\end{array}$ & $\begin{array}{l}\text { Gender, Strain, } \\
\text { Age or weight at } \\
\text { time of testing }\end{array}$ & ITI & $\begin{array}{l}\text { Effect on NOR } \\
\text { performance }\end{array}$ & Reference \\
\hline & $\begin{array}{l}\text { PNU-282987 (N-(3R)-1- } \\
\text { Azabicyclo[2.2.2]oct-3-yl-4- } \\
\text { chloro-benzamide } \\
\text { monohydrochloride hydrate), } \\
\text { selective } \alpha 7 \mathrm{nAChR} \text { full agonist, } \\
10 \mathrm{mg} / \mathrm{kg} \text {, s.c., } 15 \text { days }\end{array}$ & $\begin{array}{l}\text { scPCP, } 2 \mathrm{mg} / \mathrm{kg} \text {, i.p. } \\
\text { (twice daily for } 7 \\
\text { days, } 7 \text { days } \\
\text { washout) }\end{array}$ & $\begin{array}{l}\text { Female Lister } \\
\text { Hooded rats, 200- } \\
220 \mathrm{~g}\end{array}$ & $1 \mathrm{~min}$ & $\begin{array}{l}\downarrow \mathrm{scPCP} \text { treated rats } \\
\uparrow 15 \text {-day } 10 \mathrm{mg} / \mathrm{kg} \\
\text { PNU-282987 in scPCP } \\
\text { treated rats }\end{array}$ & $\begin{array}{l}\text { (McLean et al., } \\
\text { 2011) }\end{array}$ \\
\hline & $\begin{array}{l}\text { PNU-282987, } 0.3 \text { and } 1 \mathrm{mg} / \mathrm{kg} \text {; i.p. } \\
30 \text { min prior acquisition } \\
\text { A-85380 (3-[(2S)-2- } \\
\text { Azetidinylmethoxy]-pyridine } \\
\text { dihydrochloride), } \alpha 4 \beta 2 \mathrm{nAChR} \\
\text { agonist, acute; } 0.1 \text { and } 0.3 \mathrm{mg} / \mathrm{kg} \text {; } \\
\text { i.p., } 30 \text { min prior acquisition }\end{array}$ & $\begin{array}{l}\text { scPCP, } 2 \mathrm{mg} / \mathrm{kg} \text {, i.p. } \\
\text { (twice daily for } 7 \\
\text { days, } 7 \text { days } \\
\text { washout) }\end{array}$ & $\begin{array}{l}\text { Female Long Evans } \\
\text { rats, (8-9 weeks } \\
\text { old) }\end{array}$ & $1 \mathrm{~min}$ & $\begin{array}{l}\downarrow \mathrm{scPCP} \text { treated rats } \\
\downarrow 0.3 \mathrm{mg} / \mathrm{kg} \mathrm{PNU}- \\
282987 \text { in scPCP } \\
\text { treated rats } \\
\uparrow 1 \mathrm{mg} / \mathrm{PNU}-282987 \\
\text { in scPCP treated rats } \\
\downarrow 1 \mathrm{mg} / \mathrm{kg} \text { PNU- } \\
282987+1 \mathrm{mg} / \mathrm{kg} \\
\mathrm{MLA} \text { in scPCP treated } \\
\text { rats } \\
\downarrow 0.1 \mathrm{mg} / \mathrm{kg} \mathrm{A}-85380 \\
\text { in scPCP treated rats } \\
\uparrow 0.3 \mathrm{mg} / \mathrm{kg} \text { A- } 85380 \\
\text { in scPCP treated rats } \\
\downarrow 0.3 \mathrm{mg} / \mathrm{kg} \text { A- } 85380+ \\
\text { Dh } \beta \mathrm{E} \text { in scPCP treated } \\
\text { rats }\end{array}$ & $\begin{array}{l}\text { (Miyauchi et } \\
\text { al., 2016) }\end{array}$ \\
\hline & $\begin{array}{l}\text { PNU-120596 (N-(5-chloro-2,4- } \\
\text { dimethoxyphenyl)-N'-(5-methyl-3- } \\
\text { isoxazolyl)urea), } \alpha 7 \text {-nAChRs } \\
\text { PAM type I; } 1 \text { or } 3 \mathrm{mg} / \mathrm{kg} \text {, i.p.; } 30\end{array}$ & $\begin{array}{l}\text { Ketamine, } 20 \mathrm{mg} / \mathrm{kg} \text {, } \\
\text { i.p., } 45 \mathrm{~min} \text { prior } \\
\text { acquisition }\end{array}$ & $\begin{array}{l}\text { Male Sprague- } \\
\text { Dawley rats, } 200- \\
250 \mathrm{~g}\end{array}$ & $24 \mathrm{hr}$ & $\begin{array}{l}\downarrow \text { ketamine treated rats } \\
\uparrow 1 \text { and } 3 \mathrm{mg} / \mathrm{kg} \text { PNU- } \\
120596 \text { in ketamine } \\
\text { treated rats }\end{array}$ & $\begin{array}{l}\text { (Nikiforuk et } \\
a l ., 2016 \mathrm{~b})\end{array}$ \\
\hline
\end{tabular}




\begin{tabular}{|c|c|c|c|c|c|c|}
\hline \multirow[t]{2}{*}{ Receptor target } & Drug/compound administered & $\begin{array}{c}\text { NMDAR model and } \\
\text { treatment }\end{array}$ & $\begin{array}{l}\text { Gender, Strain, } \\
\text { Age or weight at } \\
\text { time of testing }\end{array}$ & ITI & $\begin{array}{l}\text { Effect on NOR } \\
\text { performance }\end{array}$ & Reference \\
\hline & min prior to ketamine injection & & & & & \\
\hline & 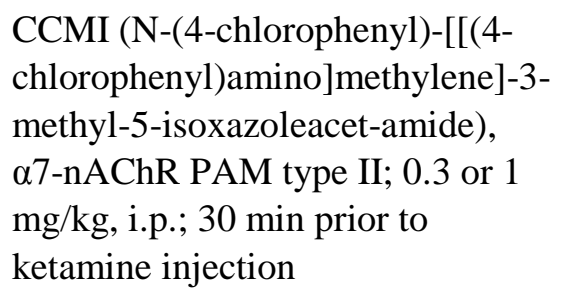 & & & & $\begin{array}{l}\uparrow 0.3 \text { and } 1 \mathrm{mg} / \mathrm{kg} \\
\text { CCMI in ketamine } \\
\text { treated rats }\end{array}$ & \\
\hline & $\begin{array}{l}\text { Galantamine, acetylcholinesterase } \\
\text { inhibitor (AChE) nAChRs } \\
\text { allosteric modulator; } 1 \text { or } 3 \mathrm{mg} / \mathrm{kg} \text {; } \\
\text { i.p.; } 30 \text { min prior to ketamine } \\
\text { injection }\end{array}$ & & & & $\begin{array}{l}\uparrow 1 \text { and } 3 \mathrm{mg} / \mathrm{kg} \\
\text { galantamine in } \\
\text { ketamine treated rats } \\
\uparrow 0.3 \text { and } 1 \mathrm{mg} / \mathrm{kg} \mathrm{A-}\end{array}$ & \\
\hline & $\begin{array}{l}\text { A-582941(octahydro-2-methyl-5- } \\
\text { (6-phenyl-3-pyridazinyl)- } \\
\text { pyrrolo[3,4-c]pyrrole) orthosteric } \\
\alpha 7-n A C h R \text { agonist, } 0.3 \text { or } 1 \\
\text { mg/kg, i.p; } 30 \text { min prior to } \\
\text { ketamine injection }\end{array}$ & & & & treated rats & \\
\hline & $\begin{array}{l}\text { Lu AF58801 ((1S,2S)-2-Phenyl- } \\
\text { cyclopropanecarboxylic acid } \\
\text { [alpha(R)-(4-ethoxy-phenyl)-2- } \\
\text { hydroxy-ethyl]-amide), } \alpha 7- \\
\text { nAChRs PAMs; acute; } 10-30 \\
\text { mg/kg, p.o. }\end{array}$ & $\begin{array}{l}\text { scPCP, } 5 \mathrm{mg} / \mathrm{kg} \text {, i.p., } \\
\text { (twice daily for } 7 \\
\text { days, } 7 \text { days } \\
\text { washout) }\end{array}$ & $\begin{array}{l}\text { Male Lister } \\
\text { Hooded rats 220- } \\
240 \mathrm{~g}\end{array}$ & $1 \mathrm{hr}$ & $\begin{array}{l}\downarrow \mathrm{scPCP} \text { treated rats } \\
\downarrow 10 \mathrm{mg} / \mathrm{kg} \mathrm{Lu} \\
\text { AF58801 in scPCP } \\
\text { treated rats } \\
\uparrow 30 \mathrm{mg} / \mathrm{kg} \mathrm{Lu} \\
\text { AF58801 in scPCP } \\
\text { treated rats }\end{array}$ & $\begin{array}{l}\text { (Eskildsen et } \\
\text { al., 2014) }\end{array}$ \\
\hline Serotonin 5- & Lurasidone, $5-\mathrm{HT}_{2 \mathrm{~A}}, 5-\mathrm{HT}_{7}, \mathrm{D}_{2}$ & scPCP, $2 \mathrm{mg} / \mathrm{kg}$, i.p. & & & $\downarrow$ scPCP treated rats & \\
\hline
\end{tabular}




\begin{tabular}{|c|c|c|c|c|c|c|}
\hline Receptor target & Drug/compound administered & $\begin{array}{c}\text { NMDAR model and } \\
\text { treatment }\end{array}$ & $\begin{array}{c}\text { Gender, Strain, } \\
\text { Age or weight at } \\
\text { time of testing }\end{array}$ & ITI & $\begin{array}{l}\text { Effect on NOR } \\
\text { performance }\end{array}$ & Reference \\
\hline \multirow[t]{3}{*}{$\begin{array}{l}\text { hydroxytryptamine } \\
\text { receptor antagonists } \\
(5-\mathrm{HT})\end{array}$} & $\begin{array}{l}\text { antagonist, and } 5-\mathrm{HT}_{1 \mathrm{~A}} \text { receptor } \\
\text { partial agonist AAPD; acute; } 0.1 \\
\mathrm{mg} / \mathrm{kg} ; \text { i.p. }\end{array}$ & $\begin{array}{l}\text { (twice daily for } 7 \\
\text { days, } 7 \text { days } \\
\text { washout) }\end{array}$ & $\begin{array}{l}\text { Evans (8-9 weeks } \\
\text { old) }\end{array}$ & & $\begin{array}{l}\uparrow 0.1 \mathrm{mg} / \mathrm{kg} \text { lurasidone } \\
\text { in scPCP treated rats } \\
\downarrow 0.1 \mathrm{mg} / \mathrm{kg} \text { lurasidone } \\
+0.6 \mathrm{mg} / \mathrm{kg} \\
\text { WAY } 100635 \text { in scPCP } \\
\text { treated rats }\end{array}$ & Meltzer, 2012) \\
\hline & $\begin{array}{l}\text { Lurasidone, sub-chronic; } 0.1 \text { and } 1 \\
\mathrm{mg} / \mathrm{kg} \text {; i.p.; (twice daily for } 7 \text { days, } \\
7 \text { days washout }-30 \text { min prior to } \\
\text { scPCP) }\end{array}$ & $\begin{array}{l}\text { scPCP, } 2 \mathrm{mg} / \mathrm{kg} \text {, i.p. } \\
\text { (twice daily for } 7 \\
\text { days, } 7 \text { days } \\
\text { washout) }\end{array}$ & $\begin{array}{l}\text { Female Long- } \\
\text { Evans ( } 8-9 \text { weeks } \\
\text { old) }\end{array}$ & $1 \mathrm{~min}$ & $\begin{array}{l}\downarrow \mathrm{scPCP} \text { rats } \\
\downarrow 0.1 \mathrm{mg} / \mathrm{kg} \mathrm{sc}- \\
\text { lurasidone in scPCP } \\
\text { treated rats } \\
\uparrow 1 \mathrm{mg} / \mathrm{kg} \mathrm{sc}- \\
\text { lurasidone in scPCP } \\
\text { treated rats } \\
\downarrow 1 \mathrm{mg} / \mathrm{kg} \mathrm{sc}- \\
\text { lurasidone }+0.6 \\
\mathrm{mg} / \mathrm{kg} \text { WAY } 100635 \text { in } \\
\mathrm{scPCP} \text { treated rats }\end{array}$ & $\begin{array}{l}\text { (Horiguchi et } \\
\text { al., 2012) }\end{array}$ \\
\hline & $\begin{array}{l}\text { Lurasidone, } 0.03 \text { and } 0.1 \mathrm{mg} / \mathrm{kg} \text {; } \\
\text { i.p.; } 30 \mathrm{~min} \text { prior to acquisition }\end{array}$ & $\begin{array}{l}\text { scPCP, } 2 \mathrm{mg} / \mathrm{kg} \text {, i.p. } \\
\text { (twice daily for } 7 \\
\text { days, } 7 \text { days } \\
\text { washout) }\end{array}$ & $\begin{array}{l}\text { Female Long Evans } \\
\text { rats, (8-9 weeks } \\
\text { old) }\end{array}$ & $1 \mathrm{~min}$ & $\begin{array}{l}\downarrow \mathrm{scPCP} \text { rats } \\
\downarrow 0.03 \mathrm{mg} / \mathrm{kg} \\
\text { lurasidone in scPCP } \\
\text { treated rats } \\
\uparrow 0.1 \mathrm{mg} / \mathrm{kg} \text { lurasidone } \\
\text { in scPCP treated rats } \\
\uparrow 0.03 \mathrm{mg} / \mathrm{kg} \\
\text { lurasidone }+0.1 \mathrm{mg} / \mathrm{kg} \\
\mathrm{A}-85380 \text { in } \mathrm{scPCP} \\
\text { treated rats }\end{array}$ & $\begin{array}{l}\text { (Miyauchi et } \\
\text { al., 2016) }\end{array}$ \\
\hline
\end{tabular}




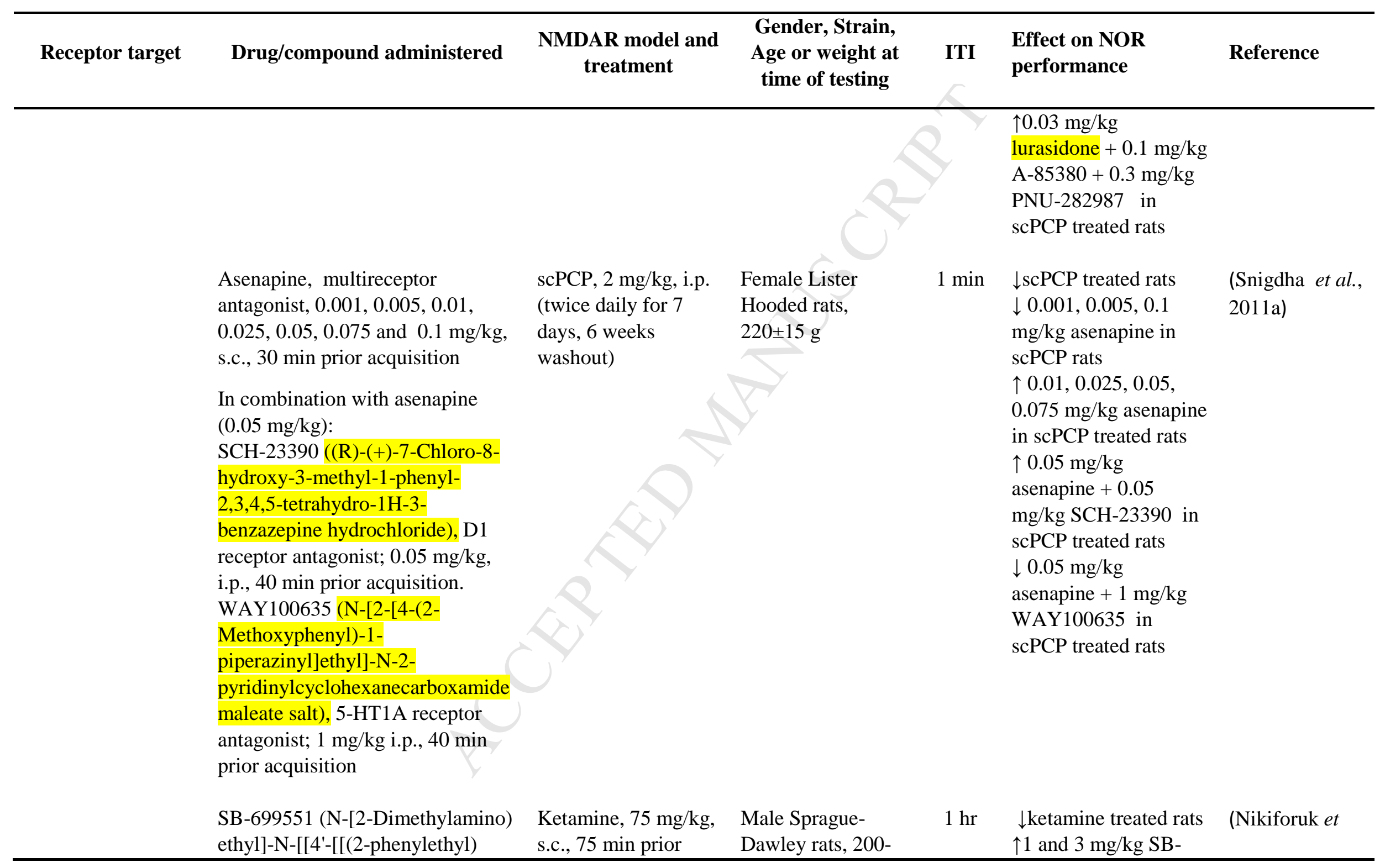




\begin{tabular}{|c|c|c|c|c|c|c|}
\hline Receptor target & Drug/compound administered & $\begin{array}{l}\text { NMDAR model and } \\
\text { treatment }\end{array}$ & $\begin{array}{l}\text { Gender, Strain, } \\
\text { Age or weight at } \\
\text { time of testing }\end{array}$ & ITI & $\begin{array}{l}\text { Effect on NOR } \\
\text { performance }\end{array}$ & Reference \\
\hline & $\begin{array}{l}\text { amino]methyl][1,1'-biphenyl]-4- } \\
1] \text { methyl] cyclopentane } \\
\text { propanamide dihydrochloride), } 5 \text { - }_{\mathrm{HT}_{5 \mathrm{~A}} \text { receptor antagonist; } 0,0.3,1 \text {, }} 3 \mathrm{mg} / \mathrm{kg} \text {; i.p.; } 30 \text { min prior to the } \\
\text { ketamine injection }\end{array}$ & acquisition & $250 \mathrm{~g}$ & & $\begin{array}{l}699551 \text { in ketamine } \\
\text { treated rats }\end{array}$ & al., 2016a) \\
\hline \multirow[t]{2}{*}{$\begin{array}{l}\text { Dopamine receptors } \\
\qquad\left(\mathrm{D}_{3} \text { and } \mathrm{D}_{4}\right)\end{array}$} & $\begin{array}{l}\text { PD168077 (N-(Methyl-4-(2- } \\
\text { cyanophenyl)) piperazinyl-3- } \\
\text { methylbenzamide), } \mathrm{D}_{4} \text { agonist, } \\
0.3,1,3,10 \mathrm{mg} / \mathrm{kg}, \text { s.c., } 45 \mathrm{~min} \\
\text { prior acquisition }\end{array}$ & $\begin{array}{l}\text { scPCP, } 1 \mathrm{mg} / \mathrm{kg}, \text { i.p. } \\
\text { (twice daily for } 7 \\
\text { days, } 6 \text { weeks } \\
\text { washout) }\end{array}$ & $\begin{array}{l}\text { Female Lister } \\
\text { Hooded rats, } 200 \mathrm{~g}\end{array}$ & $1 \mathrm{~min}$ & $\begin{array}{l}\downarrow \mathrm{scPCP} \text { treated rats } \\
\downarrow 0.3,1 \mathrm{mg} / \mathrm{kg} \\
\mathrm{PD} 168077 \text { in } \mathrm{scPCP} \\
\text { rats } \\
\uparrow 3,10 \mathrm{mg} / \mathrm{kg} \\
\mathrm{PD} 168077 \mathrm{in} \mathrm{scPCP} \\
\text { treated rats }\end{array}$ & $\begin{array}{l}\text { (Sood et al., } \\
\text { 2011) }\end{array}$ \\
\hline & $\begin{array}{l}\text { PD168077 } \mathrm{D}_{4} \text { agonist, } 0.5,1.5 \\
\mathrm{mg} / \mathrm{kg}, \text { i.p., } 30 \text { min prior } \\
\text { acquisition } \\
\text { In combination with PD } 168077 \\
(0.5 \mathrm{mg} / \mathrm{kg}) \text { : } \\
\text { lurasidone, weak } \mathrm{D}_{4} \text { antagonist, } \\
0.03 \mathrm{mg} / \mathrm{kg} \text {, i.p., } 30 \text { min prior } \\
\text { acquisition } \\
\text { clozapine, strong } \mathrm{D}_{4} \text { antagonist, } \\
0.1 \mathrm{mg} / \mathrm{kg}, \text { i.p., } 30 \text { min prior } \\
\text { acquisition }\end{array}$ & $\begin{array}{l}\text { scPCP, } 2 \mathrm{mg} / \mathrm{kg} \text {, i.p. } \\
\text { (twice daily for } 7 \\
\text { days, } 6 \text { weeks } \\
\text { washout) }\end{array}$ & $\begin{array}{l}\text { Female Long- } \\
\text { Evans rats (8-9 } \\
\text { weeks old) }\end{array}$ & $1 \mathrm{~min}$ & $\begin{array}{l}\downarrow \mathrm{scPCP} \text { treated rats } \\
\downarrow 0.5 \mathrm{mg} / \mathrm{kg} \text { PD } 168077 \\
\text { in scPCP treated rats } \\
\uparrow 1.5 \mathrm{mg} / \mathrm{kg} \text { PD } 168077 \\
\text { in scPCP treated rats } \\
\downarrow 0.5 \mathrm{mg} / \mathrm{kg} \\
\mathrm{PD} 168077+0.03 \\
\mathrm{mg} / \mathrm{kg} \text { lurasidone in } \\
\mathrm{scPCP} \text { treated rats } \\
\uparrow 0.5 \mathrm{mg} / \mathrm{kg} \text { PD168077 } \\
+0.1 \mathrm{mg} / \mathrm{kg} \text { clozapine } \\
\text { in scPCP treated rats }\end{array}$ & $\begin{array}{l}\text { (Miyauchi et } \\
\text { al., 2017) }\end{array}$ \\
\hline
\end{tabular}




\begin{tabular}{|c|c|c|c|c|c|c|}
\hline Receptor target & Drug/compound administered & $\begin{array}{l}\text { NMDAR model and } \\
\text { treatment }\end{array}$ & $\begin{array}{l}\text { Gender, Strain, } \\
\text { Age or weight at } \\
\text { time of testing }\end{array}$ & ITI & $\begin{array}{l}\text { Effect on NOR } \\
\text { performance }\end{array}$ & Reference \\
\hline & $\begin{array}{l}\text { Cariprazine, dopamine } \mathrm{D}_{3} / \mathrm{D}_{2} \\
\text { receptor partial agonist, } 0.05,0.1 \text {, } \\
0.25 \mathrm{mg} / \mathrm{kg} \text {, p.o., } 60 \mathrm{~min} \text { prior } \\
\text { acquisition }\end{array}$ & $\begin{array}{l}\mathrm{scPCP}, 2 \mathrm{mg} / \mathrm{kg} \text {, i.p. } \\
\text { (twice daily for } 7 \\
\text { days, } 6 \text { weeks } \\
\text { washout) }\end{array}$ & $\begin{array}{l}\text { Female Lister } \\
\text { Hooded rats, 225- } \\
300 \mathrm{~g}\end{array}$ & & $\begin{array}{l}\downarrow \mathrm{scPCP} \text { treated rats } \\
\uparrow 0.05,0.1 \mathrm{mg} / \mathrm{kg} \\
\text { cariprazine in scPCP } \\
\text { treated rats } \\
\downarrow 0.25 \mathrm{mg} / \mathrm{kg} \\
\text { cariprazine in scPCP } \\
\text { treated rats }\end{array}$ & $\begin{array}{l}\text { (Neill et al, } \\
2016 \text { ) }\end{array}$ \\
\hline \multirow[t]{2}{*}{$\begin{array}{c}\text { Gamma- } \\
\text { aminobutyric acid } \\
(\mathrm{GABA})_{\text {A }} \text { receptor }\end{array}$} & $\begin{array}{l}\text { AA29504 (N1-Ethoxycarbonyl- } \\
\text { N4-[(2,4,6- } \\
\text { trimethylpheny)lmethyl]-1,2,4- } \\
\text { triaminobenzene), a positive } \\
\text { modulator of extrasynaptic } \text { GABA }_{\mathrm{A}} \text { receptors; } 1,2,5 \\
\text { mg/kg s.c., } 30 \text { min prior }_{\text {acquisition }}\end{array}$ & $\begin{array}{l}\text { scPCP, } 1 \mathrm{mg} / \mathrm{kg} \text {, i.p. } \\
\text { (twice daily for } 7 \\
\text { days, } 7 \text { days } \\
\text { washout) }\end{array}$ & $\begin{array}{l}\text { Female Lister } \\
\text { Hooded rats, } \\
360 \pm 15 \mathrm{~g}\end{array}$ & $1 \mathrm{~min}$ & $\begin{array}{l}\downarrow \mathrm{scPCP} \text { treated rats } \\
\downarrow 1.25 \mathrm{mg} / \mathrm{kg} \\
\text { gaboxadol in scPCP } \\
\text { treated rats } \\
\uparrow 2.5 \text { and } 5.0 \mathrm{mg} / \mathrm{kg} \\
\text { gaboxadol in scPCP } \\
\text { treated rats } \\
\downarrow 2 \mathrm{mg} / \mathrm{kg} \mathrm{AA} 29504 \\
\text { in scPCP treated rats } \\
\uparrow 1 \text { and } 5 \mathrm{mg} / \mathrm{kg} \\
\mathrm{AA} 29504 \mathrm{in} \mathrm{scPCP} \\
\text { treated rats } \\
\uparrow 1.25 \mathrm{mg} / \mathrm{kg} \\
\text { gaboxadol }+2 \mathrm{mg} / \mathrm{kg} \\
\text { AA29504 in } \mathrm{scPCP} \\
\text { treated rats }\end{array}$ & $\begin{array}{l}\text { (Damgaard et } \\
\text { al., 2011) }\end{array}$ \\
\hline & $\begin{array}{l}\text { RO4938581 (3-bromo-10- } \\
\text { (difluoromethyl)-9H- } \\
\text { benzo[f]imidazo[1,5- }\end{array}$ & $\begin{array}{l}\text { scPCP, } 5 \mathrm{mg} / \mathrm{kg} \text {, i.p. } \\
\text { (twice daily for } 7 \\
\text { days, } 7 \text { days }\end{array}$ & $\begin{array}{l}\text { Male Lister } \\
\text { Hooded rats; 220- }\end{array}$ & $1 \mathrm{hr}$ & $\begin{array}{l}\downarrow \mathrm{scPCP} \text { treated rats } \\
\downarrow 0.3 \mathrm{mg} / \mathrm{kg} \\
\text { RO4938581 in scPCP }\end{array}$ & $\begin{array}{l}\text { (Redrobe } \text { et al., } \\
\text { 2012) }\end{array}$ \\
\hline
\end{tabular}




\begin{tabular}{|c|c|c|c|c|c|c|}
\hline Receptor target & Drug/compound administered & $\begin{array}{c}\text { NMDAR model and } \\
\text { treatment }\end{array}$ & $\begin{array}{l}\text { Gender, Strain, } \\
\text { Age or weight at } \\
\text { time of testing }\end{array}$ & ITI & $\begin{array}{l}\text { Effect on NOR } \\
\text { performance }\end{array}$ & Reference \\
\hline & $\begin{array}{l}\text { a][1,2,4]triazolo[ } 1,5- \\
\text { d][1,4]diazepine), negative } \\
\text { modulator of } \alpha 5 \mathrm{GABA}_{\mathrm{A}} \\
\text { receptors; } 0.3 \text { and } 1 \mathrm{mg} / \mathrm{kg} \text {; p.o.; } \\
60 \text { min prior to acquisition }\end{array}$ & washout) & $240 \mathrm{~g}$ & & $\begin{array}{l}\text { treated rats } \\
\uparrow 1 \mathrm{mg} / \mathrm{kg} \text { RO4938581 } \\
\text { in } \mathrm{scPCP} \text { treated rats }\end{array}$ & \\
\hline & $\begin{array}{l}\text { PWZ-029, a partial inverse agonist } \\
\text { selective for } \alpha 5 \text {-containing } \\
\mathrm{GABA}_{\mathrm{A}} \text { receptors; } 5 \mathrm{mg} / \mathrm{kg} \text {; i.p. } 20 \\
\text { min prior acquisition }\end{array}$ & $\begin{array}{l}\text { Acute } \mathrm{MK}-801,0.1 \\
\mathrm{mg} / \mathrm{kg}, \text { i.p., } 20 \mathrm{~min} \\
\text { prior to acquisition }\end{array}$ & $\begin{array}{l}\text { Male Wistar rats } \\
\text { (9-week old); 200- } \\
250 \mathrm{~g}\end{array}$ & $1 \mathrm{hr}$ & & $\begin{array}{l}\text { (Timic } \\
\text { Stamenic et al., } \\
\text { 2015). }\end{array}$ \\
\hline \multirow[t]{2}{*}{-------- } & $\begin{array}{l}\text { SNP, nitric oxide (NO)-donor } \\
\text { sodium nitroprusside; } 5 \mathrm{mg} / \mathrm{kg} \text {; } \\
\text { i.p.; } 30 \text { min post ketamine } \\
\text { (therapeutic); } 30 \text { min prior } \\
\text { ketamine (preventative) }\end{array}$ & $\begin{array}{l}\text { Ketamine, } 30 \mathrm{mg} / \mathrm{kg} \text {; } \\
\text { i.p. } 24 \mathrm{hr} \text { prior } \\
\text { acquisition }\end{array}$ & $\begin{array}{l}\text { Male Wistar rats } \\
\text { (2- month old); } \\
250-280 \mathrm{~g}\end{array}$ & $24 \mathrm{hr}$ & $\begin{array}{l}\downarrow \text { ketamine treated rats } \\
\downarrow 5 \mathrm{mg} / \mathrm{kg} \text { SNP prior to } \\
\text { or post ketamine } \\
\downarrow \text { ketamine treated rats } \\
\downarrow 5 \mathrm{mg} / \mathrm{kg} \mathrm{SNP} \text { prior } \\
\text { ketamine } \uparrow 5 \mathrm{mg} / \mathrm{kg} \\
\text { SNP post ketamine }\end{array}$ & $\begin{array}{l}\text { (Kandratavicius } \\
\text { et al., 2015) }\end{array}$ \\
\hline & $\begin{array}{l}\text { SNP, nitric oxide (NO)-donor } \\
\text { sodium nitroprusside; } 0.3 \text { and } 1 \\
\text { mg/kg; i.p.; post acquisition }\end{array}$ & $\begin{array}{l}\text { Ketamine, } 3 \mathrm{mg} / \mathrm{kg} \text {; } \\
\text { i.p. post-acquisition }\end{array}$ & $\begin{array}{l}\text { Male Wistar rats } \\
\text { (3-month-old); } \\
\text { 250-300 g }\end{array}$ & $1 \mathrm{hr}$ & $\begin{array}{l}\downarrow \text { ketamine rats } \\
\uparrow 0.3 \text { and } 1 \mathrm{mg} / \mathrm{kg} \mathrm{SNP} \\
\text { on ketamine rats }\end{array}$ & $\begin{array}{l}\text { (Trevlopoulou } \\
\text { et al., 2016) }\end{array}$ \\
\hline \multirow[t]{2}{*}{-------- } & $\begin{array}{l}\text { Crocins, extract from Crocus } \\
\text { sativus L.; } 15 \text { and } 30 \mathrm{mg} / \mathrm{kg} \text {; post } \\
\text { acquisition }\end{array}$ & $\begin{array}{l}\text { Ketamine, } 3 \mathrm{mg} / \mathrm{kg} \text {; } \\
\text { i.p. post-acquisition }\end{array}$ & $\begin{array}{l}\text { Male Wistar rats } \\
\text { (3-month-old) 250- } \\
300 \mathrm{~g}\end{array}$ & $1 \mathrm{hr}$ & $\begin{array}{l}\downarrow \text { ketamine rats } \\
\uparrow 15 \text { and } 30 \mathrm{mg} / \mathrm{kg} \\
\text { Crocins in ketamine } \\
\text { treated rats }\end{array}$ & $\begin{array}{l}\text { (Georgiadou et } \\
\text { al., 2014) }\end{array}$ \\
\hline & $\begin{array}{l}\text { AUT00206, selective Kv3.1/3.2 } \\
\text { channel positive modulator, } 60\end{array}$ & $\begin{array}{l}\mathrm{scPCP}, 2 \mathrm{mg} / \mathrm{kg} \text {, i.p. } \\
\text { (twice daily for } 7\end{array}$ & $\begin{array}{l}\text { Female Lister } \\
\text { Hooded rats, 200- }\end{array}$ & $1 \mathrm{~min}$ & $\begin{array}{l}\downarrow \mathrm{scPCP} \text { treated rats } \\
\uparrow 60 \mathrm{mg} / \mathrm{kg} \text { AUT00206 }\end{array}$ & $\begin{array}{l}\text { (Leger et al., } \\
2015)\end{array}$ \\
\hline
\end{tabular}




\begin{tabular}{|c|c|c|c|c|c|c|}
\hline Receptor target & Drug/compound administered & $\begin{array}{l}\text { NMDAR model and } \\
\text { treatment }\end{array}$ & $\begin{array}{l}\text { Gender, Strain, } \\
\text { Age or weight at } \\
\text { time of testing }\end{array}$ & ITI & $\begin{array}{l}\text { Effect on NOR } \\
\text { performance }\end{array}$ & Reference \\
\hline 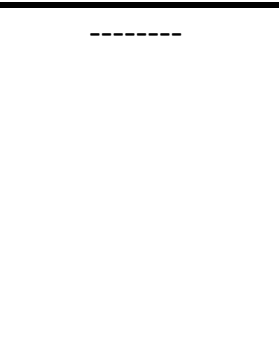 & $\begin{array}{l}\mathrm{mg} / \mathrm{kg} \text {, sub-chronic (3 weeks - } \\
\text { once daily) }\end{array}$ & $\begin{array}{l}\text { days, } 6 \text { weeks } \\
\text { washout) }\end{array}$ & $220 \mathrm{~g}$ & Y & $\begin{array}{l}\text { in scPCP treated rats } \\
\text { on day } 1,7,14,21 \text { of } \\
\text { treatment } \\
\downarrow 1 \text { day and } 1 \text { week of } \\
\text { AUT00206 washout } \\
\text { (day } 22 \& 28 \text { ) in } \\
\text { scPCP treated rats }\end{array}$ & \\
\hline
\end{tabular}




\section{Table 2}

Experimental details in operant tasks in NMDAR antagonist rodent models and effects of pharmacological agents.

\begin{tabular}{|c|c|c|c|c|c|}
\hline Test & $\begin{array}{c}\text { Drug/compound } \\
\text { \& mechanism }\end{array}$ & $\begin{array}{l}\text { NMDAR antagonist } \\
\text { used } \\
\text { \& regimen }\end{array}$ & $\begin{array}{l}\text { Gender, strain, } \\
\text { age or weight at } \\
\text { time of testing }\end{array}$ & $\begin{array}{l}\text { Effect on } \\
\text { performance }\end{array}$ & Reference \\
\hline $\begin{array}{l}\text { Reversal learning } \\
\text { (2 lever operant } \\
\text { boxes) }\end{array}$ & $\begin{array}{l}\text { Cariprazine, dopamine } \mathrm{D}_{2} / \mathrm{D}_{3} \\
\text { partial agonist, } 0.1-0.25 \mathrm{mg} / \mathrm{kg} \text { p.o., } \\
\text { acute, } 60 \text { min prior to testing. }\end{array}$ & $\begin{array}{l}\mathrm{scPCP}, 2 \mathrm{mg} / \mathrm{kg} \text {, i.p. } \\
\text { (twice daily for } 7 \text { days, } 7 \\
\text { days washout) }\end{array}$ & $\begin{array}{l}\text { Female Lister } \\
\text { Hooded rats }(225- \\
300 \mathrm{~g})\end{array}$ & $\begin{array}{l}\downarrow \mathrm{scPCP} \text { treated rats } \\
\uparrow 0.1 \& 0.25 \mathrm{mg} / \mathrm{kg} \\
\text { cariprazine in scPCP } \\
\text { treated rats }\end{array}$ & (Neill et al, 2016) \\
\hline
\end{tabular}




\begin{tabular}{|c|c|c|c|c|c|}
\hline Test & $\begin{array}{l}\text { Drug/compound } \\
\text { \& mechanism }\end{array}$ & $\begin{array}{c}\text { NMDAR antagonist } \\
\text { used } \\
\text { \& regimen }\end{array}$ & $\begin{array}{l}\text { Gender, strain, } \\
\text { age or weight at } \\
\text { time of testing }\end{array}$ & $\begin{array}{l}\text { Effect on } \\
\text { performance }\end{array}$ & Reference \\
\hline & 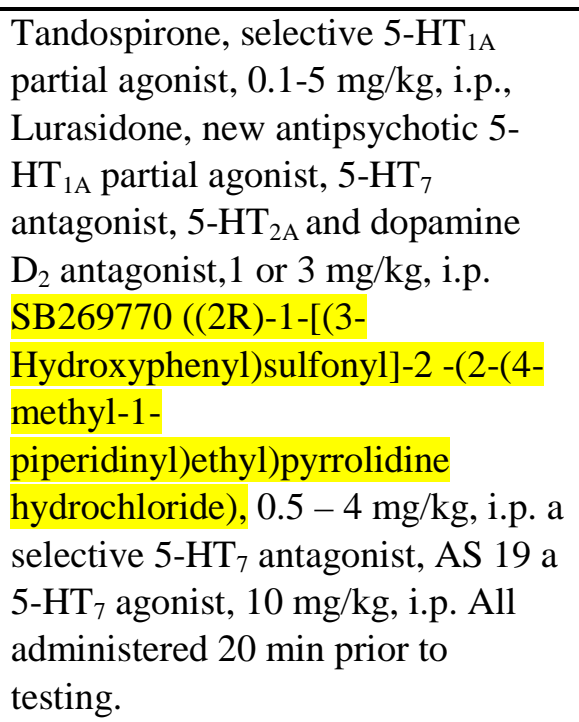 & $\begin{array}{l}\text { scPCP, } 10 \mathrm{mg} / \mathrm{kg} \text {, s.c. } \\
\text { (twice daily for } 7 \text { days, } 7 \\
\text { days washout) }\end{array}$ & $\begin{array}{l}\text { Male C57BL/6J } \\
\text { mice, }(2.5-3 \\
\text { months) } 23 \mathrm{~g}\end{array}$ & $\begin{array}{l}\downarrow \text { scPCP treated mice } \\
\uparrow 5 \mathrm{mg} / \mathrm{kg} \\
\text { tandospirone, } 4 \mathrm{mg} / \mathrm{kg} \\
\mathrm{SB} 269970,3 \mathrm{mg} / \mathrm{kg} \\
\text { lurasidone } \\
\downarrow 10 \mathrm{mg} / \mathrm{kg} \text { AS } 19 \text { in } \\
\text { scPCP treated rats }\end{array}$ & $\begin{array}{l}\text { (Rajagopal et al, } \\
\text { 2016) }\end{array}$ \\
\hline & & $\begin{array}{l}\text { Acute PCP } 0.25 \text { - } 1 \\
\mathrm{mg} / \mathrm{kg} \text {, s.c. } 30 \mathrm{~min} \text { prior } \\
\text { to testing compared to } \\
\mathrm{scPCP}, 5 \mathrm{mg} / \mathrm{kg} \text {, s.c. } \\
\text { (twice daily for } 7 \text { days, } 7 \\
\text { days washout) }\end{array}$ & $\begin{array}{l}\text { Male Lister } \\
\text { Hooded rats (180- } \\
200 \mathrm{~g})\end{array}$ & $\begin{array}{l}\downarrow \text { acute } 1 \mathrm{mg} / \mathrm{kg} \mathrm{PCP} \\
\text { treated rats } \\
\text { No effect of scPCP } \\
\text { treatment }\end{array}$ & Fellini et al, 2014 \\
\hline $\begin{array}{l}\text { Paired Associates } \\
\text { Learning }\end{array}$ & $\begin{array}{l}\text { Haloperidol, } 0.01-0.04 \mathrm{mg} / \mathrm{kg} \text { p.o. } \\
\text { Risperidone } 0.01-0.04 \mathrm{mg} / \mathrm{kg} ., \\
\text { both acute, } 30 \mathrm{~min} \text { prior to testing. }\end{array}$ & $\begin{array}{l}\text { Acute } \mathrm{MK}-801,0.025- \\
0.075 \mathrm{mg} / \mathrm{kg}, \text { s.c., } 30-60 \\
\text { min prior to testing. }\end{array}$ & $\begin{array}{l}\text { Male Lister } \\
\text { Hooded rats, }(180 \\
-200 \mathrm{~g})\end{array}$ & $\begin{array}{l}\downarrow \text { acute } 0.075 \mathrm{mg} / \mathrm{kg} \\
\text { MK-801 treated rats } \\
\downarrow \text { No reversal with } \\
\text { acute } 0.01-0.04 \mathrm{mg} / \mathrm{kg} \\
\text { haloperidol in } \mathrm{MK}-\end{array}$ & Talpos et al, 2015 \\
\hline
\end{tabular}




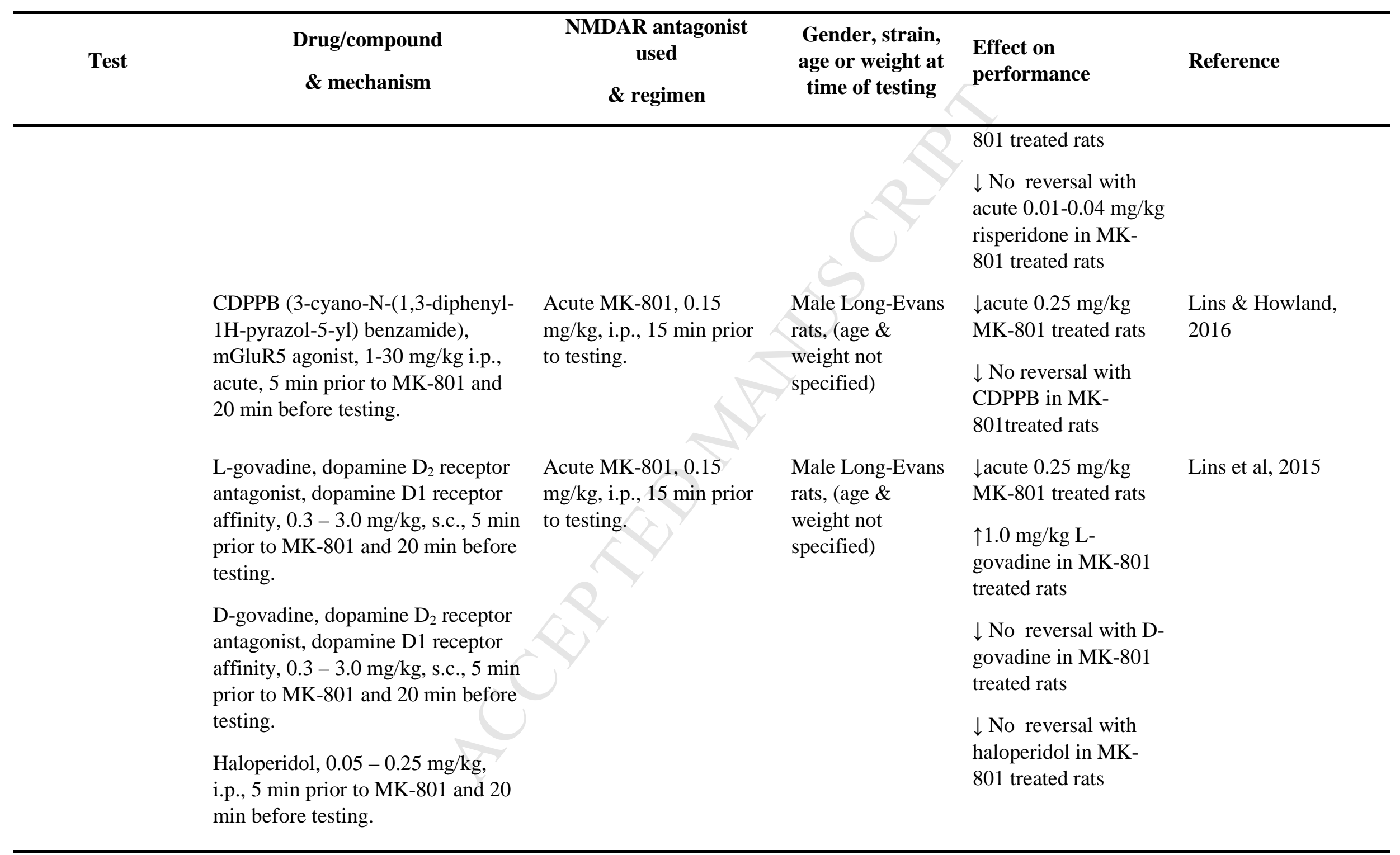




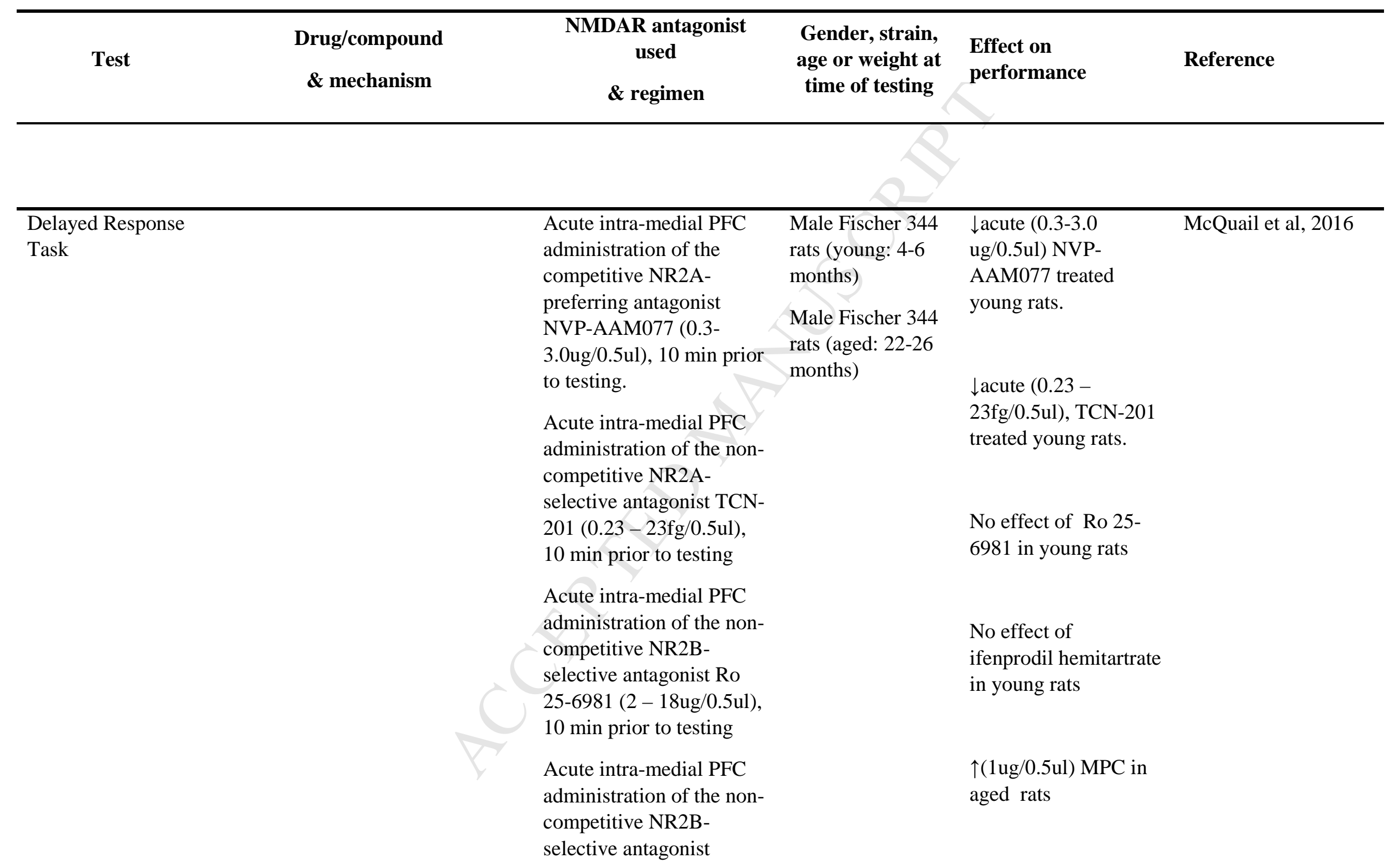




\begin{tabular}{|c|c|c|c|c|c|}
\hline Test & $\begin{array}{l}\text { Drug/compound } \\
\text { \& mechanism }\end{array}$ & $\begin{array}{c}\text { NMDAR antagonist } \\
\text { used } \\
\text { \& regimen }\end{array}$ & $\begin{array}{l}\text { Gender, strain, } \\
\text { age or weight at } \\
\text { time of testing }\end{array}$ & $\begin{array}{l}\text { Effect on } \\
\text { performance }\end{array}$ & Reference \\
\hline TUNL Task & & $\begin{array}{l}\text { Acute administration of } \\
\text { the competitive NMDA } \\
\text { receptor antagonist CPP, } \\
10 \mathrm{mg} / \mathrm{kg}, \text { i.p., } 30 \mathrm{~min} \\
\text { prior to testing. } \\
\text { Acute administration of } \\
\text { selective antagonist for } \\
\text { the GluN2B subunit- } \\
\text { containing NMDA } \\
\text { receptors Ro } 256981,6 \text { or } \\
10 \text { mg/kg, i.p., } 30 \text { min } \\
\text { prior to testing. } \\
\text { Acute intra-medial PFC } \\
\text { and acute intra- } \\
\text { dorsomedial striatum } \\
\text { administration of the } \\
\text { competitive NMDA } \\
\text { receptor antagonist AP5 } \\
\text { (1ul of a } 30 \text { mM solution), } \\
5 \text { min prior to testing }\end{array}$ & $\begin{array}{l}\text { Male Long-Evans } \\
\text { rats }\end{array}$ & $\begin{array}{l}\text { No effect of acute } \\
\text { system treatment with } \\
\text { Ro25-6981 (6 or } 10 \\
\mathrm{mg} / \mathrm{kg} \text { ) } \\
\\
\downarrow \text { both acute intra- } \\
\text { medial PFC and } \\
\text { dorsomedial striatum } \\
\text { injection (1ul of a } \\
\text { 30mM solution) AP5 } \\
\text { treated rats. }\end{array}$ & Davies et al, 2017 \\
\hline $\begin{array}{c}\text { Visual Signal } \\
\text { Detection Task }\end{array}$ & $\begin{array}{l}\text { AZD3480 ((E,2S)-N-methyl-5-(5- } \\
\text { propan-2-yloxypyridin-3-yl)pent-4- } \\
\text { en-2-amine), a novel } \alpha 4 \beta 2 \\
\text { nicotinic receptor agonist, } 0.01- \\
1.0 \mathrm{mg} / \mathrm{kg}, \text { s.c., } 30 \mathrm{~min} \text { prior to } \\
\text { testing. }\end{array}$ & $\begin{array}{l}0.05 \mathrm{mg} / \mathrm{kg}, \text { s.c. } \mathrm{MK}-801, \\
30 \mathrm{~min} \text { prior to testing }\end{array}$ & $\begin{array}{l}\text { Female Sprague- } \\
\text { Dawley rats }\end{array}$ & $\begin{array}{l}\downarrow \text { acute }(0.05 \mathrm{mg} / \mathrm{kg}) \\
\text { MK-801 treated rats. } \\
\uparrow 0.01 \& 0.1 \mathrm{mg} / \mathrm{kg} \\
\text { AZD } 3480 \text { in } \mathrm{MK}-801 \\
\text { treated rats }\end{array}$ & Rezvani et al, 2012 \\
\hline
\end{tabular}




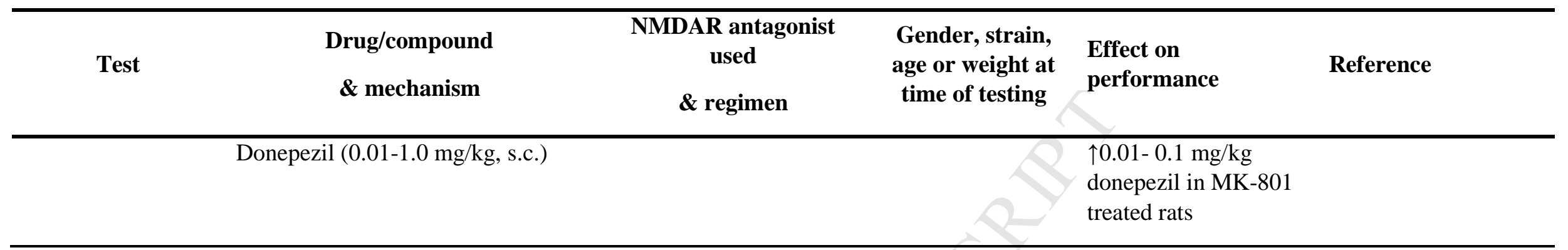

i.p.: Intraperitoneally; s.c.: subcutaneous; p.o.: per os; sc: sub-chronic; $\downarrow$ deficits; $\uparrow$ reversion of the deficits. 


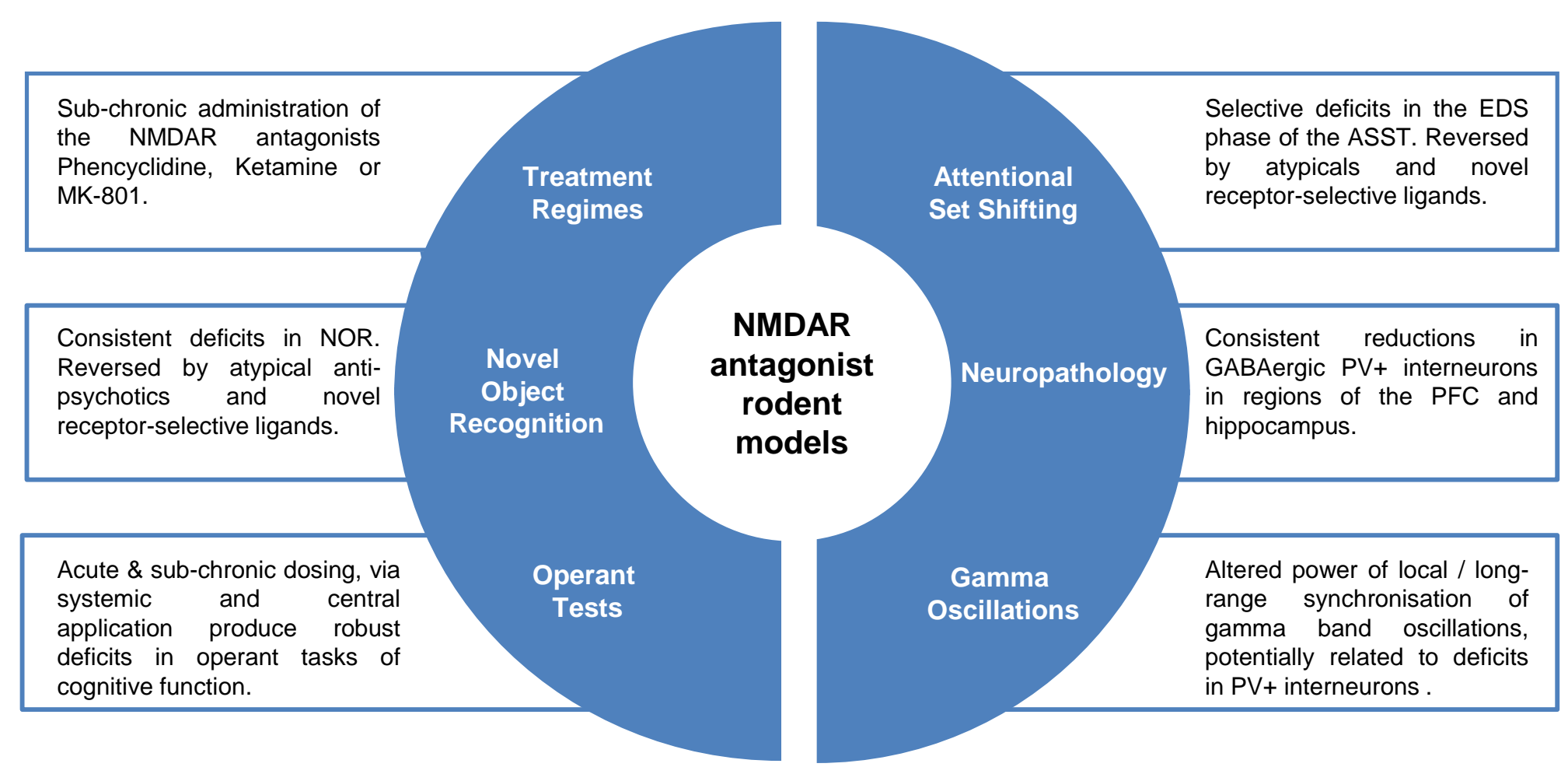

Figure 1: NMDA receptor (NMDAR) antagonist rodent models are widely utilised for studying cognitive and pathological deficits of relevance to schizophrenia. Abbreviations: NOR, novel object recognition; EDS, extra-dimensional shift; ASST, attentional set shifting task; PV+, parvalbumin positive; PFC, prefrontal cortex. 
Cadinu et al: Highlights

- NMDAR antagonists impair cognition relevant for schizophrenia in rodent tests

- New therapeutic targets for cognition are evaluated in these tests

- Effects of NMDAR antagonists on neuropathology and gamma oscillations are reviewed

- Evaluation of novel treatments on behaviour and pathophysiology is recommended

- Evaluation of novel treatments in more than one animal model is recommended 